\title{
PENATAAN HAK GUNA USAHA UNTUK KESEJAHTERAAN MASYARAKAT
}

\author{
Trie Sakti SH CN
}

\author{
BAB I \\ PENDAHULUAN
}

\section{$1.1 \quad$ Latar Belakang}

Sejarah budidaya perkebunan, berkembang pada jaman Belanda pada akhir abad 18 dengan meletakkan dasar bagi perkembangan perusahaan perkebunan di Indonesia.. Pada waktu itu, masyarakat Indonesia yang semula mengenal usaha kebun hanya sebagai usaha tambahan dari usaha tani pokoknya, yaitu pertanian pangan, diperkenalkan dengan sistem perkebunan besar dengan ciri-ciri yang sangat berbeda dengan apa yang selama ini dikenal oleh rakyat dengan usaha perkebunan rakyat, antara lain: (a) merupakan bentuk usaha pertanian berskala besar dan kompleks, (b) menggunakan areal pertanahan luas, (c) bersifat padat modal, (d) menggunakan tenaga kerja yang cukup besar, dengan pembagian kerja yang rinci dan struktur hubungan kerja yang rapi,(e) menggunakan teknologi modern; dan (f) berorientasi pada pasar.

Dengan ditetapkannya Agrarische Wet pada tahun 1870 yang pada dasarnya berisi dua hal pokok, yaitu memberi kesempatan kepada perusahaan-perusahaan swasta untuk berkembang di Indonesia, di samping "melindungi" hak-hak rakyat Indonesia atas tanahnya. Tahun 1870 dapat dikatakan sebagai saat bersejarah yang menjadi dasar utama mulai berkembangnya perkebunan swasta di Indonesia. Dua ayat yang penting bagi usaha perkebunan asing tercantum dalam ayat 4 dan 8 pasal 51 I.S. Ayat 4 memberi kesempatan untuk mendapatkan tanah dengan hak erfpacht dalam jangka panjang yaitu hingga 75 tahun untuk menjamin pengusahaan tanaman keras, sedangkan ayat 8 membuka kesempatan untuk menyewa tanah milik bangsa Indonesia. untuk pengusahaan tanaman semusim seperti tebu dan tembakau. Banyak peraturan agraria yang lahir kemudian dengan berdasar pada Agrarische Wet. Bagi usaha perkebunan partikelir, para pengusaha pada dasarnya dapat memperoleh tanah melalui tiga jalan yaitu dengan cara erfpacht, sewa, dan konsesi. Usaha perkebunan berkembang pesat di Jawa Barat dan meluas ke Jawa Tengah dan Jawa Timur serta ke Sumatera Utara Pada masa itulah, hasil perkebunan menjadi sumber penghasilan pemerintah Belanda dan dikenal sebagai "angsa bertelur emas"

Pasang surut usaha perkebunan terjadi selama pendudukan Jepang dengan rusaknya sejumlah perkebunan, yang diperparah dengan "munculnya" penduduk setempat untuk menguasai tanah-tanah perkebunan dan menggantikannya dengan tanaman pangan. Setelah masa kemerdekaan, dilakukan nasionalisasi perusahaan-perusahaan swasta Belanda yang ada di Indonesia, termasuk perkebunannya. Dengan ditandatanganinya 
persetujuan KMB (Konferensi Meja Bundar) pada bulan Desember tahun 1949, terdapat upaya untuk menguasai kembali perusahaan perkebunan oleh orang asing/bekas pemilik, dan selanjutnya pada masa sebelum UUPA itu, terdapat berbagai peraturan untuk mencegah jatuhnya tanah perkebunan ke tangan orang asing

Pada awal pelaksanaan UUPA, banyak dikeluarkan peraturan pelaksanaan terkait pengembangan perkebunan, di antaranya adalah UU nomor 38 tahun 1960 tentang penggunaan dan penetapan luas tanah untuk tanaman-tanaman tertentu. Jatuhnya harga minyak pada awal tahun 1980-an telah mendorong pemerintah untuk mengembangkan komoditi ekspor andalan non-migas seperti perkebunan dan kehutanan guna membiayai Program Pelita. Kebijakan itu mendorong dibukanya areal hutan dan dikembangkan areal perkebunan dengan Hak Guna Usaha (HGU) di luar Jawa. Dengan semakin meningkatnya pembangunan ekonomi pada periode tahun 1990-an telah mendorong berbagai pihak untuk menguasai tanah dengan skala besar untuk usaha di bidang perkebunan dan agrobisnis. Maka berkembanglah areal perkebunan dengan skala besar terutama di Provinsi Riau, Jambi, Sumatera Selatan, Kalimantan dan Maluku. Komoditi utama yang dikembangkan adalah kelapa sawit, karet, kakao dan kopi untuk memenuhi pasar ekspor dan industri dalam negeri..

Ketentuan mengenai HGU ditetapkan dalam Pasal 28 sampai dengan Pasal 34 UUPA. Menurut Pasal 28 dan 29 pengertian HGU pada intinya adalah hak untuk mengusahakan tanah yang dikuasai langsung oleh Negara dalam jangka waktu 25 sampai 35 tahun, yang dapat diperpanjang dengan jangka waktu paling lama 25 tahun guna perusahaan pertanian, perikanan atau peternakan, dengan paling sedikit 5 hektar. Bila luasnya 25 hektar atau lebih harus memakai investasi modal yang layak dan teknik pertanian yang baik sesuai dengan perkembangan zaman. Di dalam Pasal 34 ditegaskan bahwa HGU hapus karena tanahnya ditelantarkan. Ketentuan lebih lanjut yang ditetapkan PP 40/96, mengatur luasan, jangka waktu kewajiban pemegang HGU dan pencabutan HGU berdasarkan kriteria yang ditetapkan oleh instansi teknis.

Dewasa ini, peranan sektor perkebunan merupakan salah satu sektor strategis dalam perekonomian Indonesia. Menurut Direktorat Jenderal Perkebunan, pada akhir akhir tahun 2003, luas usaha di bidang perkebunan mencapai areal 17,41 juta hektar, dengan rata-rata peningkatan selama periode $2000-2003$ sekitar 3,7 \% per tahun). Dengan meningkatnya luas areal tersebut, memberi pengaruh produksi meningkat, volume ekspor dan nilai ekspor juga meningkat. Nilai ekspor yang menjadi devisa Negara pada tahun 2003 sekitar US \$ 5163 juta. Sementara itu tenaga kerja yang terserap diperkirakan sekitar 17,5 juta orang. Selanjutnya Nilai Produk Domestik Bruto (PDB) pada tahun 2003 sebesar Rp 44,94 trilyun. Hasil usaha bidang perkebunan itu, selain dari usaha besar yang luasnya sekitar 6,8 juta hektar juga tidak terlepas dari dukungan usaha perkebunan rakyat yang luasnya sekitar 10,6 juta hektar

Di samping keberhasilan dari sisi ekonomi makro, perkembangan usaha perkebunan mempunyai sejumlah permasalahan pertanahan yang terkait dengan aspek kebijakan, sosial ekonomi dan penataan wilayah. 
Dari aspek kebijakan, pemerintah lebih mendorong pertumbuhan perkebunan besar katimbang usaha perkebunan rakyat, padahal usaha ini potensinya dua kali usaha perkebunan besar. Secara nasional luas penguasaan perkebunan rakyat 1,6 hektar/pekebun, sedangkan rata-rata luas usaha perkebunan HGU sekitar 3665 hektar/unit usaha. Dukungan HGU selama ini juga lebih berorientasi pada skala yang relatif luas, padahal dalam kondisi saat ini, potensi skala luasan besar hanya tersedia di Kalimantan dan Papua.

Dari aspek sosial ekonomi, hasil penelitian Puslitbang BPN pada tahun 2005, terdapat kecenderungan semakin luas HGU yang dikuasai pemegang hak semakin besar pula potensi tanah HGU tersebut cenderung menjadi terlantar. Di sekitar perkebunan HGU yang terlantar itu, banyak penduduk miskin yang lapar tanah usaha sehingga antara kemiskinan-tanah terlantar dan penggarapan tanah perkebunan oleh rakyat menjadi saling berkaitan.

Dari segi penataan wilayah, banyak usaha perkebunan yang tidak sesuai dengan tata ruang wilayah sehingga perlu diatur kembali penggunaan dan pemanfaatan tanahnya yang cenderung ke arah usaha non pertanian, namun terkendala dengan aspek penguasaan pemilikan tanah perkebunan, terlebih yang tergolong sebagai aset negara.

Adanya Program Pembaruan Agraria Nasional merupakan upaya bersama seluruh komponen bangsa untuk menata kembali struktur pemilikan, penguasaan, penggunaan dan pemanfaatan tanah sesuai dengan prinsip tanah untuk keadilan dan kesejahteraan rakyat. Selengkapnya, tujuan PPAN adalah (1) menata kembali ketimpangan struktur penguasaan dan penggunaan tanah ke arah yang lebih adil, (2) mengurangi kemiskinan, (3) menciptakan lapangan kerja, (4) memperbaiki akses rakyat kepada sumber-sumber ekonomi, terutama tanah, (5) mengurangi sengketa dan konflik pertanahan, (6) memperbaiki dan menjaga kualitas lingkungan hidup, dan (7) meningkatkan ketahanan pangan.

Apabila kita cermati, keseluruhan tujuan PPAN di atas bermuara pada peningkatan kesejahteraan rakyat dan penyelesaian berbagai permasalahan bangsa. Namun demikian, dalam pelaksanaannnya tidak tertutup kemungkinan dapat menimbulkan potensi sengketa dan masalah baru yang tidak kita inginkan bersama. Kemungkinan potensi sengketa dimaksud bisa lahir akibat kekurangpahaman kita bersama terhadap pelaksanaan Program Pembaruan Agraria Nasional yang strategis ini. Untuk itu diperlukan penyamaan persepsi, kesatuan gerak dan langkah semua pihak.

Program Pembaruan Agraria Nasional merupakan perwujudan dari peran BPN yang merupakan instansi pemerintah sebagai pelaksana kewenangan Pasal 2 ayat (2) UUPA dan sekaligus menjadi pelaksana kewenangan Pasal 2 ayat (2) UUPA dan sekaligus menjadi pelaksana Pembaruan Agraria sebagaimana diamanatkan TAP IX/MPR/2001 tentang Pembaruan Agraria dan Pengelolaan Sumberdaya Alam mengamanatkan kepada pemerintah antara lain melaksanakan penataan kembali penguasaan, pemilikan, penggunaan dan pemanfaatan tanah (landreform) yang berkeadilan dengan memperhatiakn kepemilikan tanah untuk rakyat, serta menyelesaikan konfli-konflik yang 
berkenaan dengan sumberdaya alam yang timbul selama ini sekaligus dapat mengantisipasi potensi konflik dimasa mendatang guna menjamin terlaksananya penegakan hukum.

Selanjutnya, Keputusan MPR-RI Nomor 5/MPR-RI/2003 tentang penugasan kepada Pimpinan MPR-RI untuk menyampaikan Saran atas Pelaksanaan Putusan MPR-RI oleh Presiden, DPR, BPK, MA pada Sidang Tahunan MPR-RI Tahun 2003, memerintahkan kepada Presiden dan DPR untuk melaksanakan Pembaruan Agraria, antara lain menyelesaikan berbagai konflik dan permasalahan di bidang agrarian secara proporsional dan adil, mulai dari permasalahan hukumnya sampai dengan implementasi di lapangan,menyusun peraturan perundang-undangan yang berhubungan dengan pembaruan agrarian, dan mempermudah pemberian akses tanah terhadap masyarakat kecil, khususnya petani.

Demikian juga dalam Pidato Politik Awal Tahun 2007 pada tanggal 31 Januari 2007, Presiden Republik Indonesia menyatakan secara tegas arah kebijakannya mengenai pertanahan, sebagaimana terlihat dari pernyataannya sebagai berikut:

"Program Reforma Agraria ... secara bertahap ...akan dilaksanakan mulai tahun 2007 ini. Langkah itu dilakukan dengan mengalokasikan tanah bagi rakyat termiskin yang berasal dari hutan konversi dan tanah lain yang menurut hukum pertanahan kita boleh diperuntukkan bagi kepentingan rakyat. Inilah yang saya sebut sebagai prinsip Tanah untuk Keadilan dan Kesejahteraan Rakyat ...(yang) saya anggap mutlak untuk dilkakukan".

Dalam rangka mewujudkan Tanah untuk Keadilan dan Kesejahteraan Rakyat tersebut, prinsip-prinsip pengelolaan pertanahan harus: (1) memberikan kontribusi nyata dan melahirkan sumber-sumber baru kemakmuran rakyat; (2) meningkatkan tatanan kehidupan bersama yang lebih berkeadilan dalam kaitannya dengan penguasaan, pemilikan, penggunaan dan pemanfaatan tanah; (3) menjamin keberlanjutan sistem kemasyarakatan, kebangsaan dan kenegaraan Indonesia dengan memberikan akses seluas-luasnya pada generasi akan datang pada sumber-sumber ekonomi mayarakat dan tanah; (4) berkontribusi nyata dalam menciptakan tatanan kehidupan bersama secara harmonis dengan mengatasi berbagai sengketa dan konflik pertanahan di seluruh tanah air dan menata sistem pengelolaan yang tidak lagi melahirkan sengketa dan konflik di kemudian hari.

Sehubungan dengan hal tersebut di atas, maka diperlukan kajian kebijakan pertanahan mengenai aspek penguasaan pemilikan, penggunaan dan pemanfaatan tanah untuk pembangunan HGU perkebunan, baik usaha besar maupun skala kecil yang terintegrasi dengan usaha pengentasan kemiskinan dan penataan wilayah.

\subsection{Permasalahan Penelitian}


1. Bagaimana gambaran berbagai kebijakan pengembangan HGU perkebunan untuk skala besar maupun skala kecil ?

2. Bagaimana aspek penguasaan pemilikan penggunaan dan pemanfaatan tanah HGU perkebunan untuk skala besar maupun skala kecil terkait program pengentasan kemiskinan?

3. Bagaimana model penataan HGU perkebunan terkait pembangunan wilayah secara nasional, regional dan lokal?

\subsection{Tujuan}

1. Memperoleh gambaran berbagai kebijakan pengembangan HGU perkebunan untuk skala besar maupun skala kecil.

2. Menganalisis aspek penguasaan pemilikan penggunaan dan pemanfaatan tanah HGU perkebunan untuk skala besar maupun skala kecil. Terkait program pengentasan kemiskinan

3. Menyusun model penataan HGU perkebunan terkait pembangunan wilayah secara nasional, regional dan lokal.

\subsection{Hasil Penelitian}

1. Profil berbagai kebijakan pengembangan HGU perkebunan untuk skala besar maupun skala kecil.

2. Analisa aspek penguasaan pemilikan penggunaan dan pemanfaatan tanah HGU perkebunan untuk skala besar maupun skala kecil. Terkait program pengentasan kemiskinan

3. Model penataan HGU perkebunan terkait pembangunan wilayah secara nasional, regional dan lokal.

\subsection{Ruang Lingkup Penelitian}

1. Identifikasi pola pengusahaan HGU berbagai skala usaha ( pemanfaatan, pengusaha,skala usaha).

2. Kemanfaatan keberadaan HGU terhadap sosial ekonomi masyarakat sekitarnya dan daerah setempat (hubungan sebagai pekerja saja atau mendapat manfaat dari mereka).

3. Mempelajari praktek-praktek penyelenggaraan usaha perkebunan yang menguntungkan berbagai pihak (pengusaha, masyarakat dan daerah). 
4. Menyusun model penataan HGU pada berbagai skala usaha yang memberikan kontribusi terhadap kesejahteraan masyarakat dan daerah.

\section{BAB II \\ TINJAUAN PUSTAKA}

\subsection{Sejarah Perkebunan di Indonesia}

\subsubsection{Sebelum Kemerdekaan}

Dengan masuknya penjajah (Belanda) yang dimulai pada penghujung abad ke-17, terjadi perubahan "sistem" perkebunan di Indonesia. Masyarakat Indonesia yang semula mengenal usaha kebun hanya sebagai usaha tambahan dari usaha tani pokoknya, yaitu terutama pertanian pangan, selanjutnya diperkenalkan dengan sistem perkebunan besar dengan ciri-ciri antara lain merupakan bentuk usaha pertanian berskala besar dan kompleks, bersifat padat modal, menggunakan tenaga kerja yang cukup besar dengan pembagian kerja yang rinci dan struktur hubungan kerja yang rapi; berorientasi pada pasar dan sebagainya.

Lahirnya Agrarische Wet (Undang-Undang Agraria) pada tahun 1870 oleh Pemerintah kolonial Belanda memberi kesempatan perkebunan besar berkembang dengan pesat. Ketentuan dasar dalam Agrarische Wet pelaksanaannya diatur lebih lanjut dalam Agrarische Besluit atau Keputusan Agraria yang diundangkan dalam Staatblad 1870 No. 118. Pasal 1 dari Keputusan Agraria memuat suatu pernyataan yang dikenal sebagai domeinverklaring atau pernyataan umum tanah negara yang menyatakan bahwa "semua tanah dimana seseorang tidak dapat membuktikan bahwa tanah itu eigendom-nya, adalah tanah milik negara". Dari pernyataanini berarti semua tanah rakyat Indonesia itu menjadi tanah negara karena tanah-tanah itu dimiliki atas dasar hukum adat, dimana tidak ada ketentuan hukum adat yang sama dengan ketentuan hukum barat. Pernyataan "negara adalah pemilik semua tanah" sangat diperlukan oleh pemerintah kolonial belanda sebagai landasan hukum untuk dapat memberikan tanah dengan hak-hak barat guna kepentingan para pengusaha asing di Indonesia.

Lima ketentuan dalam Agrarische Wet kemudian ditambahkan sebagai ayat 4 sampai dengan 8 pada pasal 62 RR 1854 (yang terdiri dari 3 ayat) dan diundangkan seluruhnya menjadi pasal 51 IS (Indische Staatsregeling) (S. 1925 no. 447). Dua ayat yang penting bagi usaha perkebunan asing tercantum dalam ayat 4 dan 8 pasal 51 IS. Ayat 4 memberi kesempatan untuk mendapatkan tanah dengan hak erfpacht dalam jangka panjang yaitu hingga 75 tahun, sedangkan ayat 8 membuka kesempatan untuk menyewa tanah milik bangsa Indonesia. Hak erfpacht jangka panjang adalah untuk menjamin pengusahaan tanaman keras dan hak sewa berguna untuk pengusahaan tanaman semusim seperti tebu dan tembakau.

Pada masa pendudukan Jepang, telah mengakibatkan rusaknya sejumlah perkebunan, baik yang berada di Jawa maupun yang berada di luar jawa. Keadaan ini diperparah 
dengan munculnya penduduk setempat untuk menguasai tanah-tanah perkebunan dan menggantinya dengan tanaman pangan, setelah Jepang terusir dari Indonesia.

\subsubsection{Sesudah Kemerdekaan}

\section{a. Sebelum lahirnya UUPA}

Setelah kemerdekaan Indonesia diproklamirkan pada tanggal 17 Agustus 1945 muncul harapan baru akan kehidupan yang lebih layak. Dengan kemerdekaan ini rakyat merasa bebas untuk mendapatkan kembali tanah peninggalan nenek moyangnya selama ini dikuasai oleh kaum penjajah. Rakyat yang sejak lama haus akan tanah mulai melakukan pembabatan hutan untuk dijadikan tanah pertanian. Perbuatan ini sebetulnya merupakan kelanjutan dari apa yang telah dirintis oleh jepang yang mengerahkan rakyat untuk membongkar hutan dan onderneming milik Belanda dan kemudian menanaminya dengan tanaman pangan untuk keperluan perang. Berpuluhpuluh onderneming seketika berubah menjadi tanaman jagung, singkong, kapas dan jarak.

Keadaan menjadi berubah lagi dengan ditandatanganinya persetujuan KMB (Konferensi Meja Bundar) pada bulan Desember tahun 1949. Pasal-pasal dalam perjanjian KMB di lapangan keuangan dan perekonomian terutama berisi pengakuan oleh pemerintah RIS (Republik Indonesia Serikat) atas hak orang asing akan tanah, yaitu hak-hak konsesi dan erfpacht serta hak untuk mengusahakan selanjutnya. Bagi rakyat Indonesia, kkembalinya kekuasaan orang asing akan eksploitasi tanah berarati diambilnya isi kemerdekaan yang terpenting baginya, sehingga kembalinya pengusaha-pengusaha orderneming segera menimbulkan sengketa tanah antara rakyat yang sudah menduduki tanah dengan pihak orderneming.

Dalam perkembangan selanjutnya pada tahun 1958 terjadi peristiwa pengambilalihanan(nasionalisasi) perusahaan-perusahaan swasta Belanda yang ada di Indonesia termasuk perusahaan-perusahaan perkebunannya. Peristiwa ini dikenal dengan istilah "Nasionalisasi" perusahaan swasta belanda.

Pemerintah juga melakukan usaha-usaha untuk mengubah atau melengkapi undangundang agraria lama yang dimaksudkan untuk menyesuaikan dengan tujuan yang terkandung dalam pasal 33 UUD 45.khusus yang menyangkut masalah-masalh perkebunan, penyesuaian yang dilakukan antara lain adalah:

1. Mengubah peraturan persewaan tanah rakyat kepada perusahaan kebun besar khususnya, dan orang-orang bukan Indonesia asli pada umumnya.peraturan tentang persewaan tanah rakyat yang dimaksud adalah Grondhuur Ordonnantie dan Vorstelnlands Grondhuurreglement. Kedua pertauran tersebut diubah dengan menambah beberapa pasal didalamnya. Perubahan itu kemudian ditetapkan dengan Undang-Undang nomor 6 tahun 1952.isi dari undang-undang tersebut adalah bahwa persewaan tanah rakyat untuk tanaman tebu dan lain-lainnya yang ditunjuk menteri pertanian, hanya 
diperbolehkan paling lama satu tahun. Sebelum itu dimungkinkan adanya persewaan yang berjangka waktu panjang 21,5 tahun.

2. Menambah peraturan untuk mengawasi pemindahan hak atas tanah. Pada tahun 1952 dikeluarkan Undang-Undang darurat nomor 1 tahun 1952 tentang "pemindahan hak tanah-tanah dan barang-barang tetap lainnya yang tunduk pada hokum Eropa". Undang-Undang Darurat ini kemudian ditetapkan menjadi Undang-Undang nomor 24 tahun 1954. Dengan adanya peraturan ini maka setiap serah pakai untuk lebih dari satu tahun dan perbuatan-perbuatan yang berwujud pemindahan hak mengenai tanah-tanah dan barang-barang tetap lainnya yang tunduk pada hukum Eropa, hanya dapat dilakukan setelah mendapat ijin dari Menteri kehakiman (tetapi kemudian dengan UndangUndang nomor 76 tahun 1957 wewenang Menteri Kehakiman ini dialihkan kepada menteri Agraria). Peraturan tersebut dimaksudkan untuk mencegah atau setidak-tidaknyamengurangi jatuhnya tanah-tanah ke tangan orang asing. Selanjutnya pengawasan terhadap pemindahan hak atas tanah-tanah perkebunan diatur dalam Undang-Undang nomor 28 tahin 1954 (khusus tanahtanahperkebunan erfpacht, eigindom dan lain-lain hak kebendaan) dan Peraturan Pemerintah Nomor 35 tahun 1956 (untuk tanah-tanah perkebunan konsesi) yang kemudian diubah dengan Peraturan Pemerintah nomor 21 tahun 1959.

3. Menetapkan peraturan dan tindakan mengenai tanah-tanah perkebunan.

Pada tahun 1956 dikeluarkan Undang-Undang nomor 29 tahun 1956 yang memberi wewenang kepada menteri Agraria dan Menteri Pertanian untuk mengadakan tindakan-tindakan agar tanah

4. menetapkan kenaikan canon dan cinjs.

Canon adalah uang yang wajib dibayar oleh pemegang erfpacht setiap tahunnya kepada Negara, sedang cijn adalah uang yang wajib dibayar oleh pemegang hak konsesi perusahaan kebun besar. Untuk menyesuaikan besarnya canon dan cinj itu dengan perubahan keadaan sesudah proklamasi, maka dikeluarkanlah Undang-Undang nomor 78 tahun 1957 tentang "perubahan canon dan cinj atas hak-hak erfpacht dan konsesi guna perusahaan kebun besar".

5. Menyelesaikan soal pemakaian tanah tanpa ijin.

Untuk mencegah meluasnya pemakaian tanah-tanah perkebunan oleh rakyat tanpa ijin pengusahanya dan untuk menyelesaikan soal pemakaian tanah yang sudah ada, maka dikeluarkanlah Undang-Undang darurat nomor 1 tahun 1956. Undang-Undang ini pun kemudian dicabut lagi dengan keluarnya UndangUndang nomor 51 Prp tahun 1960 yang berisi tentang "larangan pemakaian tanah tanpa ijin yang berhak atau kuasanya".

6. Mengeluarkan Undang-Undang nomor 2 tahun 1960 tentang perjanjian bagi hasil". Perjanjian bagi hasil adalah suatu bentuk perjanjian anatara seorang 
yang berhak atas suatu bidang tanah pertanian dan orang lain yang disebut penggarap. Perjanjian bagi hasil ini semula diatur menurut hukum adat setempat, dan pada umumnya tidak menguntungkan bagi pihak penggarap karena tanah yang tersedia untuk dibagi hasilkan tidak seimbang dengan jumlah petani yang memerlukan tanah garapan. Maka untuk mengatasi hal itu, dikelaurkanlah garapan. Maka untuk mengatasi hal itu, dikeluarkanlah UndangUndang nomor 2 tahun 1960. Undang-Undang ini dikeluarkan dengan maksud agar:

a. Pembagian hasil tanah anatara pemilik dan penggarap dalam pengusahaan tanah dengan perjanjian bagi hasil dilakukan secara adil.

b. Dengan menegaskan hak-hak dan kewajiban-kewajiban pemilik dan penggarap, terjamin pula kedudukan hukum yang layak bagi para penggarap.

Jadi undang-Undang tersebut meniadakan unsur-unsur perjanjian bagi hasil yang bersifat pemerasan, sekaligus memuat pula larangan pembayaran dalam bentuk apapun yang mempunyai unsur-unsur "ijon", yaitu pembayaran yang dilakukan lama sebelum panen, dengan bunga yang sangat tinggi.

Dengan demikian tampak bahwa pemerintah Indonesia semakin kritis dalam menggunakan hukum agraria kolonial yang terpaksa masih diberlakukan sebelum terbentuk undang-undang agraria baru. Segala bentuk perubahan undang-undang dan kebijaksanaan baru yang menyangkut masalah tanah (agraria) ini dimaksudkan untuk menjamin peningkatan kesejahteraan rakyat, sesuai dengan makna yang terkandung dalam pasal 33 ayat 3 UUD 45 dan sesuai pula dengan jiwa Pancasila.

\section{b. Setelah keluarnya Undang-Undang pokok Agraria (UUPA)}

Pada awal pelaksanaan UUPA, banyak dikelaurkan peraturan-peraturan pelaksanaan yang penting, diantaranya adalah Undang-Undang nomor 38 tahun 1960 tentang penggunaan dan penetapan luas tanah untuk tanaman-tanaman tertentu.

Undang-Undang nomor 38 tahun 1960 yang kemudian disempurnakan menjadi Undang-Undang nomor 20 tahun 1964, pada hakekatnya memberi wewenang kepada pemerintah untuk menunjuk atau menetapkan daerah-daerah bagi tanaman tertentu termasuk, dengan memberikan sanksi pidana kepada mereka yang tidak mau menaatinya (Soemardjan. dkk., 1984 : 53). Dengan demikian maka para pemilik tanah didaerah-daerah yang telah ditunjuk oleh pemerintah untuk menanam tebu, tidak mempunyai pilihan lain kecuali menyediakan tanah miliknya untuk tanaman yang telah ditetapkan tersebut pada saat mendapat giliran. Dalam pelaksanaan selanjutnya, ternyata pengadaan areal tanaman tebu dari tahun ke tahun terus mengalami kesukaran. Keadaan ini disebabkan karena uang sewa tanah yang ditetapkan oleh pemerintah dirasakan oleh para petani sebagai terlalu rendah, bila dibandingkan dengan hasil tanaman padi atau palawija dalam jangka waktu yang sama, sehingga minat petani untuk menyediakan tanahnya bagi tanaman tebu juga berkurang. 
Melihat persoalan yang timbul di atas, maka pada tahun 1975 dikeluarkan Inpres nomor 9 tanggal 22 April 1975 yang menentukan bahwa untuk selanjutnya tebu tidak ditanam sendiri oleh pengelola pabrik gula di atas tanah yang disewa dari rakyat, tetapi penanaman tebu diserahkan kepada para petani untuk mengusahakannya di atas tanahnya sendiri (dikenal dengan istilah program TRI). Hal ini kiranya lebih sesuai dengan isi kandungan UUPA, terutama Pasal 10 yang menghendaki agar tanah pertanian diusahakan secara aktif oleh pemiliknya sendiri.

Di samping untuk meningkatkan dan memantapkan produksi gula dan untuk meningkatkan pendapatan petani tebu, yang menjadi tujuan utama dari dilaksanakannya program TRI ini adalah untuk menjadikan petani tebu sebagai "tuan di atas tanahnya sendiri". Namun pada kenyataannya, tujuan ini belum sepenuhnya dapat dilaksanakan. Pemilikan tanah sawah yang sempit dan hubungan "non-emosional" antara petani dengan tanaman tebu, telah mendorong petani untuk menyerahkan penggarapan tanahnya kepada ketua kelompok atau kepada petani kaya. Ini berarti sistem sewa kembali muncul dan tujuan pemerintah untuk menjadikan petani tebu menjadi "tuan di atas tanahnya sendiri" belum dapat tercapai.

Proyek PIR-BUN yang sedang digalakkan oleh pemerintah dapat pula dikatakan sebagai salah satu usaha pemerintah untuk melaksanakan program tata guna tanah tersebut. Melalui PIR-BUN, tanah-tanah yang semula tidak produktif dapat diusahakan dengan lebih efektif. Di samping itu melalui PIR-BUN diharapkan dapat tercapai asas pemerataan pembangunan dan terangkatnya taraf kehidupan rakyat, terutama para petani tuna kisma. Proyek ini didirikan berdasarkan sistem "Bapak angkat", dimana petani kuat (perkebunan besar) diharapkan membantu para petani lemah yang melakukan usaha tani disekitar perkebunan besar tersebut. Dengan demikian dapat terjadi kerjasama yang saling menguntungkan, karena perkebunan dapat memberikan bantuan atau fasilitas, sedangkan para petani menunjang bahan baku bagi kepentingan perkebunan besar tersebut.

UUPA memang telah dapat berperan dalam pembangunan bidang pertanian di Indonesia, namun untuk pelaksanaan selanjutnya kiranya masih diperlukan usahausaha untuk dapat menerapkan UUPA tersebut secara murni dan konsekuen dengan tujuan semula.

\subsection{Kebijakan Pertanahan Untuk Usaha Perkebunan}

Pasal 33 ayat (3) Undang-Undang Dasar 1945 (selanjutnya UUD 1945), menyatakan bahwa: "bumi dan air dan kekayaan alam yang terkandung di dalamnya dikuasai oleh negara dan dipergunakan untuk sebesar-besar kemakmuran rakyat". Wewenang yang bersumber pada hak menguasai dari negara tersebut digunakan untuk mencapai sebesar-besar kemakmuran rakyat dalam arti kebangsaan, kesejahteraan dan kemerdekaan dalam masyarakat di dalam negara hukum Indonesia yang merdeka, berdaulat, adil dan makmur. 
Dalam hubungannya dengan tanah, untuk melaksanakan prinsip-prinsip dasar tersebut, ditetapkan hukum agraria nasional yang tertuang dalam UUPA yang mengatur prinsip dasar mengenai pemilikan tanah dan pemanfaatan tanah yang berkeadilan. .Lebih lanjut prinsip dasar dimaksud dijabarkan secara tegas dalam Pasal 2 UUPA dalam bentuk Hak Menguasai dari Negara yang memberi wewenang untuk:

a. mengatur dan menyelenggarakan peruntukan, penggunaan, persediaan dan pemeliharaan bumi, air dan ruang angkasa;

b. menentukan dan mengatur hubungan-hubungan hukum antara orang-orang dengan bumi, air dan ruang angkasa;

c. menentukan dan mengatur hubungan-hubungan hukum antara orang-orang dan perbuatan-perbuatan hukum yang mengenai bumi, air dan ruang angkasa.

Sebagai peraturan dasar, UUPA mengatur pokok-pokok penguasaan, pemilikan, penggunaan dan pemanfaatan tanah yang pelaksanaannya lebih lanjut diatur dengan peraturan perundang-undangan. Selanjutnya pada Pasal 16 UUPA ditetapkan jenisjenis hak atas tanah yang dapat diberikan kepada perorangan maupun badan hukum, yang meliputi hak milik, hak guna usaha, hak guna bangunan, hak pakai, dan hak-hak lain yang akan ditetapkan kemudian.

Ketentuan mengenai Hak Guna Usaha (selanjutnya HGU) ditetapkan dalam Pasal 28 sampai dengan Pasal 34 UUPA. Menurut Pasal 28 dan 29 pengertian HGU pada intinya adalah hak untuk mengusahakan tanah yang dikuasai langsung oleh Negara dalam jangka waktu 25 sampai 35 tahun, yang dapat diperpanjang dengan jangka waktu paling lama 25 tahun guna perusahaan pertanian, perikanan atau peternakan, dengan paling sedikit 5 hektar. Bila luasnya 25 hektar atau lebih harus memakai investasi modal yang layak dan teknik pertanian yang baik sesuai dengan perkembangan zaman. Di dalam penjelasan Pasal 29 itu dinyatakan bahwa investasi modal dan teknik pertanian yang layak itu dimaksud untuk mendorong supaya pemakaian dan pengusahaan tanahnya dilakukan secara efisien. Selanjutnya di dalam Pasal 34 huruf e ditegaskan bahwa HGU hapus karena tanahnya ditelantarkan.

Ketentuan lebih lanjut mengenai luas maksimum HGU untuk badan hukum ditetapkan dalam Pasal 5 ayat (3) Peraturan Pemerintah Nomor 40 Tahun 1996 (selanjutnya PP 40/96), yang intinya menyatakan bahwa luasan itu mempertimbangkan pejabat yang berwenang di bidang usaha yang bersangkutan untuk usaha yang paling berdaya guna di bidang yang bersangkutan. Mengenai jangka waktu yang di dalam UUPA secara teoritis dapat diperpanjang sehingga mecapai 60 tahun, dalam Pasal 8 PP 40/96 dinyatakan bahwa setelah jangka waktu HGU berakhir, pemegang hak dapat mengajukan pembaruan HGU di atas tanah yang sama. Maka secara teoritis melalui perpanjangan dan pembaruan hak, pemegang HGU dapat menguasai tanah itu selama 85 sampai 90 tahun.

PP 40/96 juga mengatur ketentuan tentang kewajiban pemegang HGU dan pencabutan HGU. Di dalam Pasal 12 ayat (1) huruf c dinyatakan bahwa Pemegang HGU berkewajiban mengusahakan sendiri tanah HGU dengan baik sesuai dengan kelayakan usaha berdasarkan kriteria yang ditetapkan oleh instansi teknis. Selanjutnya dalam 
huruf e dinyatakan bahwa Pemegang HGU wajib memelihara kesuburan tanah, mencegah kerusakan sumberdaya alam dan menjaga kelestarian kemapuan lingkungan hidup sesuai dengan peraturan perundang-undangan yang berlaku.

Mengenai pencabutan HGU, dinyatakan dalam PP 40/96 Pasal 17 ayat (1) huruf b butir 1), yang intinya menyatakan bahwa HGU hapus karena dibatalkan haknya oleh pejabat yang berwenang sebelum jangka waktu karena tidak terpenuhinya kewajiban-kewajiban pemegang hak dan/atau dilanggarnya ketentuan-ketentuan sebagaimana dimaksud dalam Pasal 12, Pasal 13 dan/atau Pasal 14; serta ketentuan huruf e, yaitu ditelantarkan.

\subsection{Kebijakan lain berkaitan dengan Perkebunan}

Usaha perkebunan merupakan salah satu sektor strategis dalam perekonomian Indonesia. Menurut Direktorat Jenderal Perkebunan, pada akhir akhir tahun 2003, luas usaha di bidang perkebunan mencapai areal 17,41 juta hektar, dengan rata-rata peningkatan selama periode 2000 - 2003 sekitar 3,7 \% per tahun). Dengan meningkatnya luas areal tersebut, memberi pengaruh produksi meningkat, volume ekspor dan nilai ekspor juga meningkat. Nilai ekspor yang menjadi devisa Negara pada tahun 2003 sekitar US \$ 5163 juta. Sementara itu tenaga kerja yang terserap diperkirakan sekitar 17,5 juta orang. Selanjutnya Nilai Produk Domestik Bruto (PDB) pada tahun 2003 sebesar Rp 44,94 trilyun.

Hasil usaha bidang perkebunan itu, tidak terlepas dari dukungan bidang pertanahan, khususnya yang berkaitan dengan hak atas tanah untuk usaha perkebunan, antara lain jenis hak atas tanahnya, luas usaha, jangka waktu, pengaturan kebun terlantar.

Pada tahun 2004, telah dikeluarkan Undang-Undang nomor 18 tahun 2004 yang mengatur tentang Perkebunan. Dalam peraturan ini diatur berbagai hal yang berkaitan dengan penyelenggaraan perkebunan.

\subsubsection{Jenis Hak Atas Tanah Untuk Perkebunan}

Menurut Pasal 9 ayat (1) dan (2), Undang-undang Nomor 18 Tahun 2004 Tentang Perkebunan (selanjutnya UU 18/04), menyatakan bahwa kepada pelaku usaha perkebunan diberikan hak atas tanah berupa Hak Milik, Hak Guna Usaha (HGU), Hak Guna Bangunan dan/atau Hak Pakai. Lahan HGU dapat berasal dari Tanah Negara, Lahan Kawasan Hutan dan Tanah Adat/Hak Ulayat. Pemberian hak milik untuk mendukung usaha perkebunan rakyat, perorangan secara sederhana. HGU diberikan kepada Badan Usaha di bidang perkebunan untuk areal tanah yang diusahakan tanaman perkebunan, HGB diberikan kepada Badan Usaha yang memperoleh HGU itu, untuk pembangunan pabrik dan emplasemen, dan sarana maupun prasarana pendukung usaha perkebunan

2.3.2. Luas Minimum dan Maksimum 
Menurut Pasal 10 ayat (1) dan (2) UU 18/04, Menteri Pertanian menetapkan luas maksimum dan minimum lahan untuk usaha perkebunan berpedoman kepada jenis tanaman, ketersediaan tanah sesuai agroklimat, tingkat kepadatan penduduk, modal, kapasitas pabrik, kondisi geografis dan perkembangan geografis. Berdasarkan Keputusan Menteri Pertanian Nomor 357/Kpts/HK.350/5/2002 tentang Pedoman Perijinan Usaha perkebunan (IUP), ditetapkan ketentuan yang intinya menyatakan:

* Luas minimum usaha perkebunan yang memerlukan IUP adalah $25 \mathrm{Ha}$.

* Luas maksimum untuk setiap perusahaan atau group adalah $20000 \mathrm{Ha}$ atau 100 $000 \mathrm{Ha} u n t u k$ seluruh Indonesia untuk semua komoditi kecuali tebu, yaitu 60000 Ha untuk setiap propinsi dan $150000 \mathrm{Ha}$ untuk seluruh Indonesia. Khusus untuk propinsi Nanggroe Aceh Darussalam dan Papua disesuaikan dengan peraturan yang berlaku.

* Luas maksimum tersebut tidak berlaku untuk:

$>$ Badan Usaha Milik Negara yang berbentuk Perum dan BUMD

$>$ Badan Usaha yang seluruh atau sebagian besar sahamnya dimiliki oleh Pemerintah Pusat atau Daerah.

$>$ Badan Usaha yang seluruh atau sebagian besar sahamnya dimiliki oleh masyarakat atau dalam rangka go public.

\subsubsection{Jangka Waktu Pemberian HGU}

Pasal 11 UU 18/04 menetapkan bahwa HGU untuk usaha perkebunan diberikan paling lama 35 tahun dan diperpanjang paling lama 25 tahun, selanjutnya dapat diperbarui lagi selama 35 tahun oleh instansi yang berwenang di bidang pertanahan. Perpanjangan dan atau pembaruan, sesuai dengan PP 40/96 tentang Hak Guna Bangunan dan Hak Guna Usaha, dapat dilakukan selambat-lambatnya 2 tahun sebelum HGU tersebut berakhir, dengan syarat:

* Tanahnya masih diusahakan dengan baik sesuai dengan keadaan, sifat dan tujuan pemberian hak.

* Syarat-syarat pemberian hak dipenuhi dengan baik oleh pemegang hak.

* Pemegang hak masih memenuhi syarat sebagai pemegang hak.

\subsubsection{Pembinaan Perusahaan Perkebunan}

Pembinaan melalui SK Men.Pertanian No. 486.1/Kpts/OT.100/10/03 tentang Pedoman Klasifikasi Perusahaan Perkebunan. Pelaksanaan dilakukan Dinas Perkebunan Provinsi untuk setiap 3 tahun sekali. Aspek-aspek yang dinilai meliputi aspek manajemen, fisik kebun, pengolahan hasil, social ekonomi dan lingkungan. Dari hasil klasifikasi diperolh kebun kelas I (Baik Sekali), kelas II (Baik), kelas III (Cukup), kelas IV (Kurang) dan kebun kelas V (Kurang Sekali). 
Bagi Kebun Kelas I,II dan III dapat direkomendasi untuk perpanjangan/pembaharuan HGU. Bagi kebun kelas IV dan V perlu memperbaiki kelas kebunnya untuk perpanjangan HGU. Berdasarkan Pasal 12 UU 18/04, Menteri Pertanian berwenang mengusulkan kepada instansi pertanahan untuk menghapus HGU apabila menurut penilaian Menteri, HGU yang bersangkutan tidak dimanfaatkan sesuai dengan rencana dipersyaratkan dan diterlantarkan selama 3 tahun berturut-turut sejak diberikan HGUnya.

\subsection{Penertiban dan Pendayagunaan Tanah Terlantar di Areal Perkebunan}

Menurut data Direktorat Jenderal Perkebunan, pada akhir Tahun 2003 terdapat sekitar $57902 \mathrm{Ha}$ areal HGU perkebunan besar yang diokupasi rakyat dan tergolong tanah terlantar karena dimanfaatkan tidak sesuai dengan peruntukkan hak atas tanahnya. Keadaan yang bersifat indikasi di seluruh Indonesia itu, secara rinci telah didata dalam suatu studi kasus di Kabupaten Cianjur, Provinsi Jawa Barat oleh Deputi Pengendalian Pertanahan dan Pemberdayaan Masyarakat pada Tahun 2004.

Hasil evaluasi terhadap 34 HGU perkebunan skala besar dengan luas sekitar 25623 hektar, sebagian besar seluas 23732 hektar (92,62 \%) adalah sesuai dengan rencana tata ruang wilayah. Meskipun sebagian kebun tidak sesuai dengan rencana tata ruang wilayah, namun keberadaan kebun itu masih dapat ditolerir. Sementara itu, dari aspek penggunaan dan pemanfaatan tanah, sekitar 15791 hektar sesuai dengan tujuan pemberian haknya, 8315 hektar penggunaan tanahnya mendukung peruntukan HGU, dan terdapat sekitar 1517 hektar areal HGU yang tidak digunakan sesuai peruntukan HGUnya. Pada umumnya perusahaan pemegang HGU menguasai sebagian besar tanahnya. Dari 34 perusahaan pemegang HGU menunjukkan tanah yang masih dikuasai perusahaan meliputi areal seluas 20575 hektar atau sekitar $80 \%$ areal HGU. Terdapat lima perusahaan yang tidak lagi menguasai tanah HGU yang dimiliki. Penyebab utamanya adalah penjarahan oleh masyarakat, seperti pada areal perkebunan Cigombong milik PT Cikenceng dan perkebunan Mariawati milik PT Mutiara Bumi Parahyangan.

Hasil evaluasi Deputi Pengendalian Pertanahan dan Pemberdayaan Masyarakat terhadap Hasil evaluasi pelaksanaan Kep.Ka.BPN 24/02, pada umumnya Kantor Pertanahan mengalami kendala teknis, administratif maupun dukungan pembiayaan dalam pelaksanaan ketentuan tersebut. Kendala internal di BPN, antara lain belum jelasnya unit kerja yang bertugas dan bertanggung jawab terhadap pelaksanaan penertiban dan pendayagunaan tanah terlantar, terbatasnya tenaga pelaksana serta belum jelasnya pembiayaan untuk pelaksanaan kegiatan tersebut. Di samping itu kendala eksternal antara lain mekanisme hubungan koordinatif berbagai pihak yang melibatkan instansi teknis di Pusat dan Daerah, Pemerintah Daerah serta masyarakat setempat.

Lebih lanjut evaluasi pada tahun 2003 terhadap tanah terlantar HGU di Kabupaten Cianjur menunjukkan bahwa secara teknis keberadaan tanah terlantar dapat diidentifikasi wujud dan penyebabnya. Tanah yang tidak sesuai dengan peruntukan 
pada areal HGU itu, disebabkan adanya penjarahan kebun oleh masyarakat sehingga merubah penggunaan tanah yang semula untuk perkebunan menjadi tegalan, serta adanya sengketa di Pengadilan.

Berdasarkan hasil identifikasi dan luasan tanah yang masih dikuasai secara fisik oleh perusahaan, dapat ditetapkan tindakan pengendaliannya, yaitu tindakan optimalisasi, penertiban dan konversi. Optimalisasi dimaksud untuk memelihara penggunaan tanah yang ada agar sesuai dengan peruntukan HGU serta menambah kesuburan tanahnya. Penertiban dimaksud untuk menyesuaikan penggunaan tanah saat kini dengan peruntukan HGU agar tujuan pemberian HGU dapat tercapai. Konversi dimaksud untuk merubah penggunaan tanah yang ada agar sesuai dengan peruntukan HGU.

Secara operasional, tanah-tanah HGU yang penggunaan tanahnya melebihi $75 \%$ merupakan tanah kosong, tegalan atau semak belukar dapat digolongkan terindikasi tanah terlantar. Rekomendasi yang diberikan terhadap tanah-tanah tersebut adalah:

a. Optimalisasi, apabila areal HGU lebih $75 \%$ ditanami dengan tanaman pokok

b. Penertiban, apabila areal HGU 50-75\% ditanami dengan tanaman pokok

c. Konversi, apabila areal HGU kurang dari $50 \%$ ditanami dengan tanaman pokok

Walaupun telah ditetapkan arah tindakan pengendaliannya, namun langkah operasional pendayagunaan tanah terlantar itu belum dapat ditetapkan lebih konkrit karena memerlukan koordinasi dengan istansi terkait maupun Pemerintah Daerah.

\subsection{Hasil Penelitian Puslitbang mengenai Studi Kasus Tanah HGU Perkebunan}

Berdasarkan hasil penelitian Puslitbang BPN pada tahun 2005, ditemukan bahwa faktor-faktor terjadinya tanah terlantar itu menyangkut masalah teknis manajemen dan sosial-ekonomi. Berikut diuraikan keadaan faktor-faktor yang pada hakekatnya ketiga faktor itu tidak dapat dipisah secara tegas karena saling terkait satu sama lain.

\subsubsection{Faktor Teknis Manajemen Usaha}

Tanah terlantar pada areal HGU di provinsi Kalimantan Selatan dan Sulawesi Selatan, sebagian disebabkan faktor teknis manajemen usaha. Sebagaimana diketahui kondisi tanah di Kalimantan Selatan dan Sulawesi Selatan yang menjadi areal HGU umumnya penggunaan tanah semula adalah alang-alang dan semak belukar yang miskin hara, sehingga memerlukan investasi untuk pembukaan tanah dan teknis manajemen usaha yang memadai.

Hasil evaluasi di Kalimantan Selatan menunjukkan bahwa ada indikasi areal HGU yang tanahnya terlantar tidak layak untuk usaha perkebunan. Dalam hal ini ketika proposal teknis kelayakan diajukan sebagai bahan permohonan HGU, umumnya ditangani langsung oleh instansi teknis. Sedangkan kegiatan AMDAL umumnya selalu memperoleh persetujuan dengan syarat tertentu yang bersifat umum sehingga tidak menjadi kendala dalam rangka mengamankan investasi di daerah. Di beberapa areal 
HGU, ditemukan pula areal yang tumpang tindih dengan Pertambangan (Batu Bara). Keadaan semacam ini juga dijumpai di Provinsi Sumatera Barat

Dalam hal ini timbul pertanyaan di kalangan praktisi kantor pertanahan dan kanwil BPN provinsi terhadap permohonan areal HGU itu, apakah BPN punya kewenangan untuk menetapkan bahwa tanah harus ditanami dulu baru diajukan HGU sesuai dengan keadaan dan jenis usaha serta komoditi yang diusahakan. Hal ini menyangkut pengaturan pemberian HGU yang harus jelas., karena tanah kosong yang diberi HGU setelah sekian tahun tanahnya masih ternyata masih kosong. Jadi tanah HGU itu menjadi objek spekulasi.

Mengenai tanah HGU yang menjadi objek spekulasi diperkirakan akan menjadi masalah karena sertipikat HGUnya telah dijadikan agunan di Bank serta adanya hak privelege (diutamakan) bank ketika tanah tersebut akan diusulkan untuk dinyatakan sebagai tanah terlantar. Dengan demikian tanah areal HGU yang secara pisik objek tanahnya dapat dinyatakan terlantar, namun dari segi finansial perbankan telah menghasilkan uang yang berasal dari kredit dengan jaminan HGU. Pihak Bank sendiri juga tidak dapat memblokir HGU yang dijadikan jaminan kredit, sepanjang debitor itu memenuhi kewajiban mengangsur kreditnya, walaupun sumber angsuran itu bukan berasal dari keberhasilan usaha HGUnya.

Pengaruh harga komoditi ikut mendorong terjadinya tanah terlantar. Kasus yang terjadi pada PT. Sapto Agro Unggul, perusahaan perkebunan cacao (coklat), terletak di Kecamatan Batang Alai Selatan Hulu Sungai Tengah, dengan status HGU No. 1/U/1987 tanggal 22 Mei 1987 dan Nomor 2/U/1987 tanggal 22 Mei 1987. Perkebunan ini pernah ditanami seluas 205 hektar pada tahun 1985, namun setelah itu tidak terlihat aktifitas lagi di atasnya. Penyebab terlantarnya perkebunan tersebut adalah kegagalan manajemen/pengelolaan dan kualitas cacao/harga jual yang rendah. Hal yang sama juga dialami. Demikian pula, PT.Chioda Bakti, sebuah perusahaan perkebunan Rosella di Kabupaten Tanah Laut Propinsi Kalimantan Selatan, dengan HGU No. 7/U/1979. tanahnya terlantar karena harga serat Rosella kalah bersaing dengan plastik, dan pemasaran serat Rosella yang tidak jelas.

Sementara itu, PT.Delta Kalimantan Lestari, perusahaan Tambak Udang di Takisung Kabupaten Tanah Laut Propinsi Kalimantan Selatan selaku pemegang HGU No.1/U/1988 seluas 80 hektar, telah menterlantarkan tanah tersebut akibat kegagalan usaha dimana kualitas dan harga udang kurang kompetitif di pasar internasional/nasional, biaya pengelolaan yang tinggi, dan manajemen kurang baik. Akibat selanjutnya adalah perusahaan pemegang HGU prospeknya menurun dan bahkan ada yang sudah bangkrut usahanya. Di Kabupaten Buleleng, Provinsi Bali bahkan terdapat HGU untuk Tambak yang sampai saat ini belum dibuka, karena pengusaha tidak mampu mengusahakan tanahnya, akibat resesi ekonomi pada tahun 1998 yang lalu.

Dari uraian di atas dapat dikemukakan bahwa faktor teknis manajemen usaha sangat menentukan dalam pengelolaan HGU yang dimulai pada tahap awal permohonan 
kegiatan sudah harus dapat diidentifikasi BPN selaku instnasi yang mempunyai kewenangan dalam pemberian HGU. Langkah awal itu antara lain menyangkut kompetensi sumberdaya pelaksana dalam proses identifikasi subjek dan objek permohonan HGU dalam Panitia B.

\subsubsection{Faktor Sosial-Ekonomi}

Kasus tanah terlantar, juga berkaitan dengan aspek sosial-ekonomi, dimana pemegang HGU tidak mampu mengamankan haknya dan harus berhadapan dengan masyarakat sekitar lokasi HGU. Menurut Dinas Perkebunan Provinsi, di Kalimantan Selatan terdapat 54 perusahaan perkebunan dengan HGU, 23 perusahaan termasuk kategori reklasifikasi. Pada umumnya diokupasi masyarakat. Beberapa contoh di antaranya PT Malindo Jaya Diraja di Kabupaten. Pleihari, PT Sawit Agro Unggul di Kabupaten Hulu Sungai Tengah yang selama ini terlantar. Demikian pula PT Alam Raya ingin menyelesaikan pemanfaatan sesuai HGU, tetapi sebagian besar sudah diokupasi rakyat. tanah telah digarap petani setempat dengan tanaman tegalan, sedangkan tanaman karet yang ada disadap petani.

Apa yang terjadi di Kalimantan Selatan itu, terjadi pula di provinsi Sulawesi Selatan, Bali, Sumatera Barat dan provinsi lainnya, dimana masyarakat menduduki tanah perkebunan dengan alasan belum diberikan ganti kerugian atau mengklaim sebagai tanah milik masyarakat adat setempat.

Akibat okupasi itu, luasan HGU di bawah skala usaha ekonomi sehingga produktivitasnya menurun dan akhirnya semakin luas kebun yang tidak dipelihara dengan baik. Penetapan klasifikasi perkebunan yang termasuk dalam kategori tidak produktif (Kelas IV dan Kelas V), tidak hanya parameter pisik kebun, namun mempertimbangkan aspek manajemen kebun, budidaya tanaman, pengolahan hasil dan aspek lingkungan sosial ekonomi masyarakat setempat. Pemerintah Daerah tidak ada kewenangan menanganinya karena secara teknis ijin usaha perkebunan berada di Menteri Pertanian, sementara HGUnya ditangani oleh Badan Pertanahan Nasional. 


\section{BAB III \\ PENDEKATAN PENELITIAN}

\subsection{Pendekatan Penelitian}

Tanah merupakan karunia Tuhan YME kepada Bangsa Indonesia sehingga pengelolaannya harus berdayaguna untuk kepentingan sebesar-besar kemakmuran rakyat. Prinsip dasar itu sudah ditetapkan dalam Pasal 33 ayat (3) UUD 1945 dan Pasal 1 UUPA. Lebih lanjut UUPA menegaskan bahwa penggunaan tanah harus dilakukan oleh yang berhak atas tanah selain untuk memenuhi kepentingannya sendiri juga tidak boleh merugikan kepentingan masyarakat. Oleh karena itu, bagi pihak yang telah menguasai tanah dengan sesuatu hak sesuai ketentuan UUPA atau penguasaan lainnya, harus menggunakan dan memanfaatkan tanahnya sesuai keadaan, sifat dan tujuan pemberian haknya. Dengan kata lain, para pemegang hak atas tanah maupun penguasaan tertentu tidak menelantarkan tanahnya, menjadi tanah kosong atau tidak produktif.

Pemberian HGU dalam UUPA disebutkan pada intinya adalah hak untuk mengusahakan tanah yang dikuasai langsung oleh Negara dalam jangka waktu 25 sampai 35 tahun, yang dapat diperpanjang dengan jangka waktu paling lama 25 tahun guna perusahaan pertanian, perikanan atau peternakan, dengan paling sedikit 5 hektar.. Selanjutnya di dalam PP Nomor 40 tahun 1996 juga mengatur ketentuan tentang kewajiban pemegang HGU dan pencabutan HGU. Di dalam Pasal 12 ayat (1) huruf $c$ dinyatakan bahwa Pemegang HGU berkewajiban mengusahakan sendiri tanah HGU dengan baik sesuai dengan kelayakan usaha berdasarkan kriteria yang ditetapkan oleh instansi teknis. Selanjutnya dalam huruf e dinyatakan bahwa Pemegang HGU wajib memelihara kesuburan tanah, mencegah kerusakan sumberdaya alam dan menjaga kelestarian kemapuan lingkungan hidup sesuai dengan peraturan perundangundangan yang berlaku.

Dalam kenyataan menunjukkan bahwa terdapat beberapa pihak yang telah diberi HGU skala besar belum memanfaatkan tanah sebagaimana mestinya, sehingga menjadi tanah kosong, tidak produktif atau dikenal sebagai tanah terlantar. Berbagai penyebab terjadinya hal itu, antara lain krisis moneter yang berkepanjangan, adanya spekulasi tanah, ketidakmampuan perusahaan dan sebagainya.

TAP IX/MPR/2001 tentang Pembaruan Agraria dan Pengelolaan Sumberdaya Alam mengamanatkan kepada pemerintah antara lain melaksanakan penataan kembali penguasaan, pemilikan, penggunaan dan pemanfaatan tanah (landreform) yang berkeadilan dengan memperhatiakn kepemilikan tanah untuk rakyat, serta menyelesaikan konfli-konflik yang berkenaan dengan sumberdaya alam yang timbul selama ini sekaligus dapat mengantisipasi potensi konflik dimasa mendatang guna menjamin terlaksananya penegakan hukum. 
Untuk mengetahui apakah pemberian HGU yang dilaksanakan selama ini sudah sesuai dengan maksud dan tujuan pemberiannya serta apakah pemegang HGU sudah melaksanakan hak dan kewajibannya sebagaimana yang diamanatkan oleh UUPA dan peraturan pelaksanaannya maka perlu dilakukan identifikasi tanah perkebunan baik skala besar maupun kecil. Disamping itu banyaknya tanah HGU yang diokupasi oleh masyarakat dengan alasan belum dibayarkan ganti ruginya oleh perusahaan ataupun karena faktor lain perlu dilaksanakan identifikasi.

Berdasarkan hasil identifikasi tanah HGU, maka akan diketahui aspek penguasaan/pemilikan, penggunaan dan pemanfaatan tanah HGU tersebut. Tanah HGU tersebut apakah digunakan secara produktif sebagaimana tujuan pemberiannya atau ternyata diterlantarkan oleh pemegang haknya.

Hal ini penting dalam mengembangkan kebijakan pertanahan yang berkaitan dengan tanah HGU agar dapat memberikan manfaat bagi masyarakat terutama yang berada disekitarnya baik HGU skala kecil maupun skala besar. Kemudian apakah kemungkinan model yang akan digunakan dalam pengembangan HGU terkait dengan pengembangan wilayah, antara wilayah Jawa dan luar Jawa konsep pengembangannya kemungkinan akan berbeda mengingat terbatasnya lahan di Pulau Jawa sehingga untuk pulau Jawa akan diarahkan pada pengembangan HGU skala kecil sekitar 5 ha.

Dari berbagai fakta yang diperoleh di lapangan akan dapat diperoleh gambaran kemungkinan model yang paling tepat untuk diterapkan sehingga diharapkan dapat terwujud penataan HGU yang dapat memenuhi rasa keadilan dan dapat memberikan manfaat yang sebesar-besarnya bagi masyarakat miskin.

Kerangka pemikiran ini disajikan pada Gambar 3-1. 


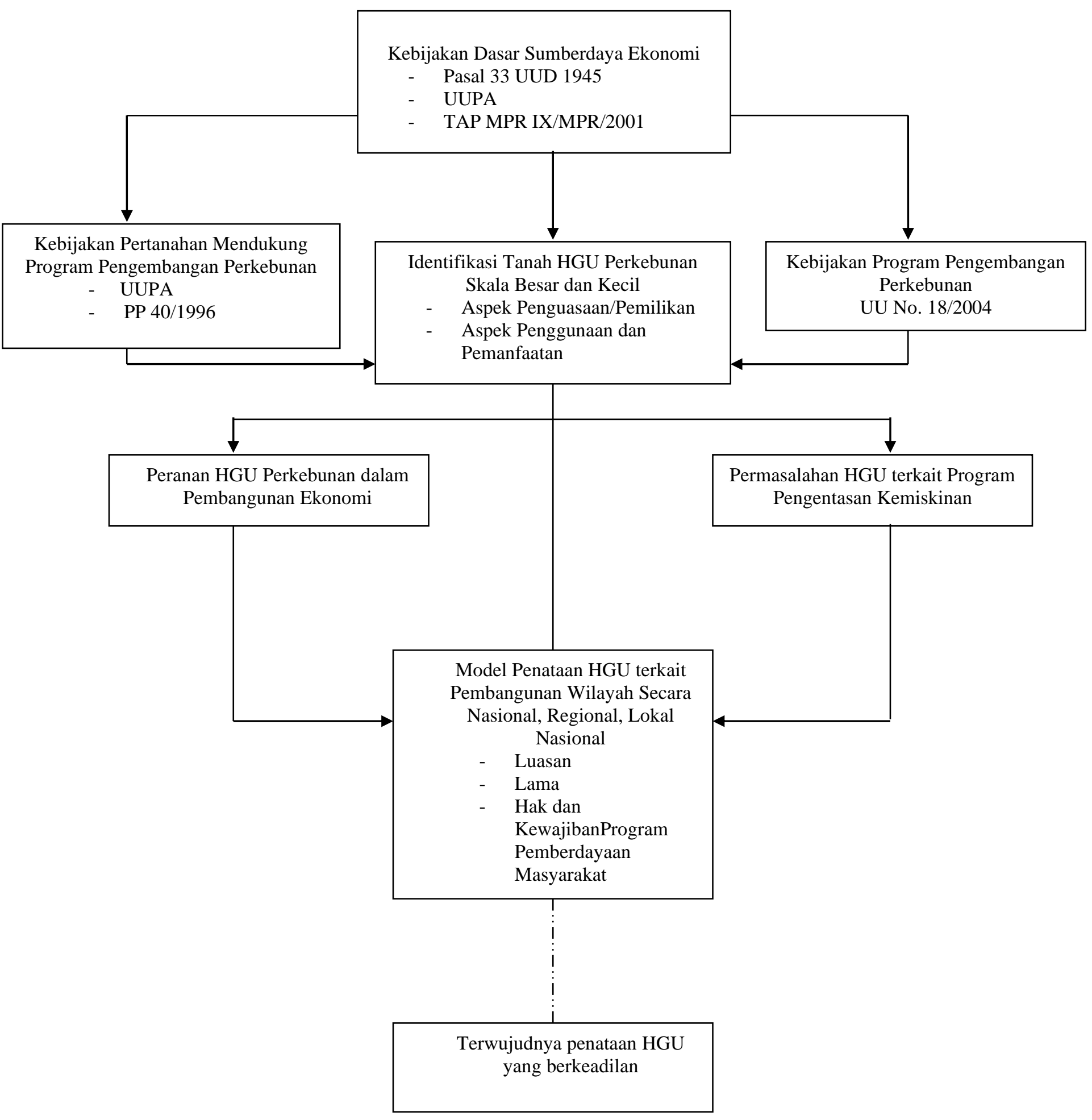

Gambar 3-1. 


\subsection{Metoda penelitian}

\subsubsection{Lokasi Penelitian}

Penelitian dilaksanakan di delapan Provinsi yaitu Provinsi Riau, Jambi, Gorontalo, Sulawesi Selatan, Sumatera Utara,Kalimantan Barat dan Provinsi Kalimantan Selatan. Provinsi Jambi digunakan sebagai lokasi uji coba dan test questionair. Di setiap provinsi ditetapkan lokasi HGU di wilayah kabupaten yang dapat mewakili profil penguasaan, pemilikan dan pemanfaatan tanah HGU dan potensi sengketa yang ditimbulkan akibat diterlantarkannya tanah HGU tersebut dan tanah HGU tersebut sudah berakhir jangka waktunya. Sampel tersebut akan ditetapkan bersama dengan Kantor Wilayah BPN Provinsi.

\subsubsection{Data Yang Digunakan dan Cara Perolehannya}

Data yang digunakan adalah data sekunder dan data primer. Data sekunder berupa: (1) daftar HGU Perkebunan di wilayah provinsi, (2) daftar HGU Perkebunan yang sudah habis jangka waktunya, (3) daftar hasil identifikasi dan penilaian keberadaan kebun yang terlantar,(4) data pelaksanaan tindak lanjut penanganan oleh Kantor Wilayah BPN Provinsi dan Kantor Pertanahan Kabupaten . Data sekunder diperoleh dari Kantor Wilayah BPN Provinsi, Dinas Perkebunan Provinsi dan Kantor Pertanahan Kabupaten.

Data primer dilakukan dengan cara memperoleh informasi melalui Focus Group Discussion (FGD) dan melalui kuesioner yang diisi oleh Kantor Pertanahan Kabupaten dan Kepala Kantor Wilayah BPN Provinsi.

\subsubsection{Populasi dan Teknik Pengambilan Contoh}

Satuan unit yang diteliti adalah HGU yang telah habis masa berlakunya dan ada yang telah diokupasi oleh masyarakat. Areal itu ditetapkan setelah memperoleh konfirmasi dari peta penggunaan tanah dan peta kebun terlantar serta data pendukung dari Kantor Wilayah BPN Provinsi, Dinas Perkebunan Provinsi dan Kantor pertanahan Kabupaten

Populasi tanah HGU yang telah berakhir jangka waktunya ditetapkan berdasarkan konfirmasi dengan Kantor Wilayah BPN Provinsi ditetapkan $1-2$ lokasi tanah HGU antara lain: sudah dilakukan identifikasi dan penilaian, sudah ada okupasi dari masyarakat, dan berpotensi menimbulkan konflik. Apakah model penataan HGU yang sesuai untuk dilaksanakan di daerah tersebut dapat dilakukan dengan pola (1) kemitraan, (2) redistribusi tanah, atau pola (3) pemberian hak serta 4) konsolidasi tanah. 


\subsubsection{Metoda Analisis dan Implikasi Kebijakan}

Penelitian ini menggunakan analisis deskriptif, yaitu dengan mempelajari kasus keberadaan tanah HGU yang terlantar di areal perkebunan dan telah berakhir jangka waktunya serta telah diokupasi oleh masyarakat, menjelaskan secara sistimatis dan akurat mengenai fakta sebab dan akibatnya, serta tindakan yang telah dilakukan beserta implikasinya.

Ciri-ciri tipe penelitian ini berkaitan dengan pelaksanaan studi, antara lain: (a). mencari informasi fakta secara rinci dengan mengamati gejala yang ada, (b) mengidentifikasi masalah tanah HGU dan potensi sengketa yang ditimbulkannya (c) melakukakan evaluasi keadaan yang terjadi beserta implikasinya (d) membuat rangkuman kesimpulan serta rekomendasi dalam rangka penataan HGU. 


\section{BAB IV}

\section{PENATAAN HAK GUNA USAHA}

\subsection{Kebijakan mengenai HGU}

Hak Guna Usaha merupakan hak yang khusus untuk mengusahakan tanah, yang bukan miliknya sendiri (tanah yang dikuasai langsung oleh Negara) guna perusahaan pertanian, perikanan dan peternakan. Hak Guna Usaha hanya dapat diberikan untuk luasan paling sedikit 5 ha. Untuk mendorong pemakaian dan pengusahaan tanah yang efisien, maka untuk tanah yang luasnya 25 hektar atau lebih harus ada investasi modal yang layak dan teknik perusahaan yang baik.

Yang dapat mempunyai HGU ialah a)warga negara Indonesia, B) badan-badan hukum yang didirikan menurut hukum Indonesia dan berkedudukan di Indonesia. Badan-badan hukum yang dapat mempunyai Hak Guna Usaha adalah badan hukum yang bermodal nasional. Hak Guna Usaha hanya terbuka kemungkinannya untuk diberikan kepada badan-badan hukum yang sebagian atau seluruhnya bermodal asing, jika hal itu diperlukan oleh undang-undang yang mengatur pembangunan nasional. Badan-badan hukum tersebut harus didirikan menurut hukum Indonesia dan berkedudukan di Indonesia.

Jelaslah bahwa keberadaan Hak Guna Usaha dalam kebijakan pertanahan, untuk meningkatkan perekonomian Indonesia, melalui peningkatan produksi yang pada gilirannya akan meningkatkan kesejahteraan rakyat. Namun tetap dalam koridor bahwa hak atas tanah mempunyai fungsi sosial, penguasaan dan pemilikan tanah yang melampaui batas tidak diperkenankan, larangan usaha yang bersifat monopoli, dan terwujudnya keadilan sosial.

Hak Guna Usaha dapat dijadikan jaminan hutang dengan dibebani hak tanggunan. Hak ini hapus karena (a) jangka waktunya berakhir, (b) dihentikan sebelum jangka waktu berakhir karena sesuatu syarat tidak dipenuhi, (c) dilepaskan oleh pemegang, (d) dicabut untuk kepentingan umum, (e) diterlantarkan, (f) tanahnya musnah, (g) pemegang haknya yang tidak lagi memenuhi syarat.

Pemberian Hak Guna Usaha lebih lanjut diatur dalam Peraturan Pemerintah No.40 Tahun 1996 tentang Hak Guna Usaha, Hak Guna Bangunan dan Hak Pakai atas Tanah. Tanah yang diberikan Hak Guna Usaha adalah tanah Negara. Jika tanah Negara yang akan diberikan hak merupakan kawasan hutan, maka haknya diberikan setelah tanah tersebut dilepaskan dari kawasan hutan. Bila tanah yang akan diberikan hak adalah tanah yang telah dilekati sesuatu hak lain maka Hak Guna Usahanya diberikan setelah hak atas tanah tersebut dilepaskan dan tanah tersebut menjadi tanah Negara. 
Batasan luas maksimum untuk tanah yang dapat diberikan dengan HGU untuk badan hukum secara tidak langsung telah diatur dalam Peraturan Menteri Negara Agraria/Kepala Badan Pertanahan Nasional No. 2 Tahun 1999 tentang Izin Lokasi. Luas tanah yang akan diberikan Hak Guna Usaha tidak dapat melebihi luas izin lokasi yang diberikan.

Untuk satu perusahaan dan perusahaan-perusahaan lain yang satu "group" perusahaan tersebut:

\begin{tabular}{|l|l|l|l|}
\hline No. & USAHA & PROVINSI & INDONESIA \\
\hline 1 & PERKEBUNAN & & \\
& $\begin{array}{l}\text { 1. KOMODITAS TEBU } \\
\text { 2. KOMODITAS LAINNYA }\end{array}$ & $60.000 \mathrm{HA}$ & $150.000 \mathrm{HA}$ \\
& $20.000 \mathrm{HA}$ & $100.000 \mathrm{HA}$ \\
& TAMBAK & & \\
& 2. DI PULAU JAWA & $100 \mathrm{HA}$ & $1.000 \mathrm{HA}$ \\
& $200 \mathrm{HA}$ & $2.000 \mathrm{HA}$ \\
\hline
\end{tabular}

Untuk Provinsi Papua maksimum luas penguasaan tanah adalah dua kali maksimum luas penguasaan tanah di luar Pulau Jawa.

Dengan pengecualian, untuk Badan Usaha Milik Negara (BUMN) yang berbentuk Perum dan Badan Usaha Milik Daerah (BUMD); Badan Usaha yang seluruh atau sebagian sahamnya dimiliki oleh Negara, baik Pemerintah maupun Pemerintah Daerah; Badan usaha yang seluruhnya atau sebagian besar sahamnya dimiliki oleh masyarakat dalam rangka "go public."

Hak Guna Usaha diberikan dengan keputusan pemberian hak oleh Kepala Badan Pertanahan Nasional RI atau Pejabat yang ditunjuk. Pemberian hak ini wajib didaftar dalam buku tanah pada Kantor Pertanahan, maka Hak Guna Usaha terjadi sejak didaftarkan.

Mengenai Tata cara pemberian Hak Guna Usaha secara lebih detail diatur dalam Peraturan Menteri Negara Agraria/Kepala Badan Pertanahan Nasional No. 3 Tahun 1999 tentang Pelimpahan Kewenangan Pemberian dan Pembatalan Keputusan Pemberian Hak atas Tanah; dan Peraturan Menteri Negara Agraria/Kepala Badan No. 9 Tahun 1999 tentang Tata Cara Pemberian dan Pembatalan Hak atas Tanah Negara dan Hak Pengelolaan. 
Pasal 29 (1) mengatur HGU diberikan untuk waktu paling lama 25 tahun, (2) untuk perusahaan yang memerlukan waktu yang lebih lama dapat diberikan HGU untuk waktu paling lama 35 tahun.

Untuk perpanjangan HGU, UUPA, Pasal 29 ayat (3), menyatakan bahwa atas permintaan pemegang hak dan mengingat keadaan perusahaannya jangka waktu dapat diperpanjang dengan paling lama 25 tahun. Namun tidak dijelaskan mengenai pembaruan hak, baik untuk Hak Guna Usaha maupun hak tanah lainnya seperti Hak Guna Bangunan dan Hak Pakai.

Definisi memperpanjang dan memperbaharui hak, terdapat dalam Penjelasan Pasal 1 UU No. 29 Tahun 1959 Tentang Peraturan-Peraturan Dan Tindakan-Tindakan Mengenai Tanah-Tanah Perkebunan, memperpanjang berarti meneruskan berlakunya sesuatu hak dengan tidak mengubah syarat-syaratnya semula dan memperbaharui berarti memberi hak baru dengan syarat-syarat yang baru pula.

Menurut PP 40 Tahun 1996, Pasal 1, perpanjangan hak adalah penambahan jangka waktu berlakunya sesuatu hak tanpa mengubah syarat-syarat dalam pemberian hak tersebut. Pembaharuan hak adalah pemberian hak yang sama kepada pemegang hak atas tanah yang dimilikinya dengan Hak Guna Usaha, Hak Guna Bangunan atau Hak Pakai sesudah jangka waktu hak tesebut atau perpanjangannya habis.

Persyaratan mengenai perpanjangan dan pembaruan Hak Guna Usaha (Pasal 9 ayat 1)

a. tanahnya masih diusahakan dengan baik sesuai dengan keadaan, sifat dan tujuan pemberian hak tersebut;

b. syarat-syarat pemberian hak tersebut dipenuhi dengan baik oleh pemegang hak; dan

c. Pemegang hak masih memenuhi syarat sebagai pemegang hak

Selanjutnya menurut Pasal 9 ayat (2), pemegang Hak Guna Usaha dilarang menyerahkan pengusahaan tanah Hak Guna Usaha kepada pihak lain, kecuali dalam hal-hal yang diperbolehkan. Perpanjangan atau pembaruan Hak Guna Usaha diajukan selambat-lambatnya dua tahun sebelum berakhirnya jangka waktu HGU tersebut (Pasal 10 ayat (1). Selanjutnya, guna kepentingan penanaman modal, permintaan perpanjangan atau pembaruan HGU dapat dilakukan sekaligus dengan membayar uang pemasukan yang ditentukan untuk itu pada saat pertama kali mengajukan permohonan HGU (Pasal 11 ayat (1). Secara lebih detail tata cara perpanjangan dan pembaruan HGU diatur dalam Peraturan Menteri Negara Agraria/Kepala Badan No. 9 Tahun 1999 tentang Tata Cara Pemberian dan Pembatalan Hak atas Tanah Negara dan Hak Pengelolaan. 
Kebijakan mengenai HGU -- pemberian, perpanjangan dan pembaruannya - disamping berdasarkan ketentuan peraturan perundang-undangan yang ada, juga harus berdasarkan prinsip-prinsip:

- berkontribusi dalam meningkatkan kesejahteraan rakyat dan melahirkan sumbersumber baru kemakmuran rakyat;

- berkontribusi dalam meningkatkan tatanan kehidupan bersama yang lebih berkeadilan dalam kaitannya dengan penguasaan, pemilikan, penggunaan dan pemanfaatan tanah;

- berkontribusi dalam menjamin keberlanjutan sistem kemasyarakatan, kebangsaan dan kenegaraan indonesia dengan memberikan akses seluasluasnya pada generasi akan datang pada sumber-sumber ekonomi masyarakat dan tanah;

- Harus berkontribusi untuk menciptakan tatanan kehidupan bersama secara harmonis dengan mengatasi berbagai sengketa dan konflik pertanahan di seluruh tanah air serta tidak melahirkan sengketa dan konflik di kemudian hari.

- Pendayagunaan HGU yang tidak digunakan dan dimanfaatkan dengan optimal.

Agar hal ini dapat tercapai dilakukan langkah sebagai berikut: pertama, melakukan identifikasi dan inventarisasi serta menyusun data base tanah perkebunan besar (HGU) di seluruh Indonesia, kedua, melakukan penertiban tanah HGU yang diterlantarkan kembali menjadi tanah yang dikuasai langsung oleh Negara, ketiga, mengalokasi tanah HGU tersebut kepada pihak lain yang membutuhkan untuk didayagunakan - termasuk petani tidak bertanah (the best use of land). Untuk mencapai hal ini, Badan Pertanahan Nasional RI telah mengkaji dan sedang melakukan penyempurnaan Peraturan Pemerintah No. 36 Tahun 1998 tentang Penertiban dan Pendayagunaan Tanah Terlantar, karena proses penertiban dalam PP ini panjang dan membutuhkan waktu serta memberikan peluang penghindaran.

\subsubsection{Peraturan lain yang berkaitan dengan HGU seperti UU Nomor 18 tahun 2004 tentang Perkebunan.}

Pasal 1 UU Nomor 18 tahun 2004 tentang Perkebunan. menyebutkan perkebunan adalah segala kegiatan yang mengusahakan tanaman tertentu pada tanah dan/atau media tumbuh lainnya dalam ekosistem yang sesuai, mengolah dan memasarkan barang dan jasa hasil tanaman tersebut, dengan bantuan ilmu pengetahuan dan teknologi, permodalan serta manajemen untuk mewujudkan kesejahteraan bagi pelaku usaha perkebunan dan masyarakat. 
Dalam pasal 22 (1) menyebutkan perusahaan perkebunan melakukan kemitraan yang saling menguntungkan, saling menghargai, saling bertanggung, saling memperkuat dan saling ketergantungan dengan pekebun, karyawan dan masyarakat sekitar perkebunan, dalam ayat (2) kemitraan usaha perkebunan sebagaimana dimaksud polanya dapat berupa:

- kerja sama penyediaan sarana produksi,

- kerja sama produksi, pengelolaan dan pemasaran,

- transpotasi,

- kerja sama operasional,

- kepemilikan saham, dan jasa pendukung lainnya.

\section{Undang-Undang Perkebunan diatur lebih lanjut dengan :}

a) Keputusan Menteri Pertanian Nomor 486.1/Kpts/OT.100/10/2003 tentang Pedoman Klasifikasi Perusahaan Perkebunan.

Dalam peraturan ini disebutkan bahwa klasifikasi dilaksanakan terhadap perusahaan perkebunan yang ada diseluruh provinsi baik dalam bentuk Perusahaan Besar Swasta Nasional/Asing maupun Perusahaan Besar Milik Negara/Daerah dan Koperasi yang memenuhi persyaratan :

- Luas areal (holding size) : $>25$

- Badan Usaha berbentuk badan hukum : Perusahaan Swasta, BUMN (PTPN/BUMD) dan Koperasi

- Hak Atas Tanah : Memiliki HGU atau HGU dalam proses perpanjangan/pembaruan

Adapun kriteria Penentuan Kelas Kebun perusahaan perkebunan dilaksanakan sebagai berikut :

- Kelas I (baik sekali)

Apabila mempunyai total bobot nilai sub system manajemen (M), sub system kebun (K), sub system pengolahan $(P)$ dan sub system social, ekonomi dan lingkungan (SEL) 80 s/d 100

- Kelas II (baik) 
Apabila mempunyai total bobot nilai sub system manajemen (M), sub system kebun (K), sub system pengolahan (P) dan sub system social, ekonomi dan lingkungan (SEL) 65 s/d 79

- Kelas III (sedang)

Apabila mempunyai total bobot nilai sub system manajemen (M), sub system kebun (K), sub system pengolahan (P) dan sub system social, ekonomi dan lingkungan (SEL) 50 s/d 64

- Kelas IV (kurang)

Apabila mempunyai total bobot nilai sub system manajemen $(M)$, sub system kebun $(K)$, sub system pengolahan $(P)$ dan sub system social, ekonomi dan lingkungan (SEL) 26 s/d 49

- Kelas V (kurang sekali)

Apabila mempunyai total bobot nilai sub system manajemen (M), sub system kebun (K), sub system pengolahan $(P)$ dan sub system social, ekonomi dan lingkungan (SEL) $<26$

b) Peraturan Menteri Pertanian Nomor 33/Permentan/OT.140/7/2006 tentang Pengembangan Perkebunan melalui Program Revitalisasi Perkebunan.

c) Peraturan Menteri Pertanian Nomor 26/Permentan/OT.140/2/2007 tentang Pedoman Perizinan Usaha Perkebunan.

Peraturan Menteri Pertanian Nomor 33/Permentan/OT.140/7/2006 tentang Pengembangan Perkebunan melalui Program Revitalisasi Perkebunan mengatur program revitalisasi perkebunan yaitu upaya percepatan pengembangan perkebunan rakyat melalui perluasan, peremajaan dan rehabilitasi tanaman perkebunan yang didukung kredit investasi perbankan dan subsidi bunga oleh pemerintah dengan melibatkan perusahaan di bidang usaha perkebunan sebagai mitra dalam pengembangan perkebunan, pengolahan dan pemasaran hasil.

Tanaman perkebunan dalam program revitalisasi ini pada tahap awal terbatas pada komoditi kelapa sawit, karet dan kakao. Dalam pasal 17 disebutkan bahwa tanah untuk pengembangan perkebunan untuk masing-masing petani peserta paling luas 4 (empat) hektar. Tanah untuk pengembangan perkebunan sebagaimana dimaksud berasal dari tanah petani, tanah adat/ulayat, tanah negara termasuk hutan konversi serta tanah lainnya yang dimungkinkan untuk pengembangan perkebunan sesuai dengan peraturan perundang-undangan. Tanah pengembangan perkebunan sebagaimana dimaksud merupakan tanah milik petani dan atau tanah yang akan menjadi hak milik petani.

Dalam pasal 28, selama masa pembangunan kebun, petani peserta tidak melakukan pembayaran pengembalian kredit investasi dan bunganya. Pengembalian kredit dilakukan oleh petani peserta setelah kebun dialihkan kepada petani peserta, paling lambat mulai tahun ke-6 sampai dengan tahun ke-13 untuk kelapa sawit dan kakao dan 
paling lambat mulai tahun ke-8 sampai dengan tahun ke-15 untuk karet (repayment period).

Adapun Peraturan Menteri Pertanian Nomor 26/Permentan/OT.140/2/2007 tentang Pedoman Perizinan Usaha Perkebunan mengatur lebih lanjut mengenai :

- Jenis dan Usaha Perkebunan,

- Syarat dan tata Cara Permohonan Izin Usaha Perkebunan,

- Kemitraan

- Perubahan Luas lahan, Jenis Tanaman dan atau Perubahan kapasitas Pengolahan serta diversifikasi Usaha

- Pembinaan dan Pengawasan

Selanjutnya dalam pasal 11 Peraturan Menteri tersebut di atas menyebutkan Perusahaan perkebunan yang memiliki IUP atau IUP-B, wajib membangun kebun untuk masyarakat sekitar paling rendah seluas $20 \%$ dari total luas areal kebun yang diusahakan oleh perusahaan.

Program Rehabilitasi Perkebunan didasarkan pada:

(1) Peraturan Menteri Pertanian RI No. 33/Permentan/OT.140/7/2006 tanggal 26 Juli 2006, tentang Pengembangan Perkebunan Melalui Program Revitalisasi Perkebunan

(2) Peraturan Menteri Keuangan RI, No. 11/PMK.06/Th 2006, tanggal 30 Nopember 2006, tentang Kredit Pengembangan Energi Nabati \& Revitalisasi Perkebunan (KPEN-RP)

(3) Perjanjian Kerjasama Pendanaan antara Departemen Keuangan RI dengan BRI No. PKP-01/KPEN_RP/DP3/2006, tanggal 20 Desember 2006, tentang penunjukan BRI sebagai Bank Pelaksana.

(4) SK Dirjen Perkebunan No. 03/Kpts/RC.110/1/07 tanggal 18 Januari 2007, tentang Satuan Biaya Maksimum Pembangunan Kebun Peserta Program Revitalisasi Perkebunan Tahun 2007.

\subsubsection{Kebijakan Perbankan}

PT. Bank Rakyat Indonesia, Tbk. juga mengeluarkan beberapa skim kredit dari pemerintah untuk merealisasikan kredit kepada petani penggarap menjadi petani pemilik atas tanah garapannya dengan memiliki sertifikasi hak milik. Skim kredit tersebut menggunakan Pola Inti-Plasma, antara lain:

\section{Kredit Perkebunan Inti Rakyat (PIR), PIR TRANS}


- Skim kredit ini penyalurannya dikaitkan dengan program transmigrasi yang dilakukan oleh pemerintah.

- Perusahaan inti diwajibkan untuk membangunkan kebun plasma yang untuk selanjutnya dikonversi/diserahkan kepada petani

\section{KKPA}

- Pembangunan kebun plasma dilakukan oleh koperasi primer yang selanjutnya diserahkan pada anggotanya.

- Perusahaan inti diwajibkan untuk membangunkan kebun inti dan pabrik pengolahan.

- Sedangkan anggota koperasi dapat membangun kebun plasma melalui koperasi \& perusahaan inti

\section{Kredit Pengembangan Energi Nabati Dan Revitalisasi Perkebunan (KPEN \& RP)}

- KPEN-RP merupakan Kredit investasi yang diberikan oleh BRI kepada petani langsung atau melalui Perusahaan Mitra, dengan memperoleh subsidi bunga dari pemerintah dalam rangka mendukung Program Pengembangan Bahan Baku Bahan Bakar Nabati (P2B4N) dan Program Revitalisasi Perkebunan (PRP).

- P2B4N merupakan upaya peningkatan produksi dan produktivitas tanaman penghasil bahan baku bahan bakar nabati untuk memenuhi kebutuhan energi alternatif.

- PRP merupakan upaya percepatan pengembangan perkebunan rakyat melalui perluasan, peremajaan, dan rehabilitasi yang didukung kredit investasi dan subsidi bunga oleh pemerintah, dengan melibatkan Perusahaan Mitra dalam pengembangan kebun, pengolahan dan pemasaran hasil.

- Target dari program ini adalah membangun kebun seluas 2 juta Ha yang terdiri dari: 1,5 juta Ha kebun kelapa sawit, kebun karet sebanyak 300 ribu $\mathrm{Ha}$, dan Kakao seluas 200 ribu Ha.

- Program pengembangan bahan bakar nabati didasarkan pada:

(1) Inpres No. 1 Tahun 2006 tentang Penyediaan dan Pemanfaatan bahan bakar nabati (Biofuel) sebagai bahan bakar lain (BBL)

(2) Menugaskan 13 Menteri, Gubernur, dan Bupati/Walikota untuk mengambil langkah-langkah percepatan dan pemanfaatan biofuel sebagai bahan bakar lain 
(3) Kepres No. 10 Tahun 2006 tentang Tim Nasional Pengembangan Bahan Bakar Nabati, dimana Dirut BRI sebagai salah satu anggota Tim Pendanaan.

Adapun kebijakan perbankan dalam hal ini BRI dalam Program Pengembangan Energi Nabati dan Revitalisasi Perkebunan (KPEN-RP) dilakukan dengan 2 (dua) Pola, yaitu (1) Pola Kemitraan untuk Kelapa Sawit, Karet, dan Kakao dan (2) Pola Non Kemitraan untuk Karet dan Kakao.

\section{Pola Kemitraan}

\section{Skim Kredit KPEN-RP}

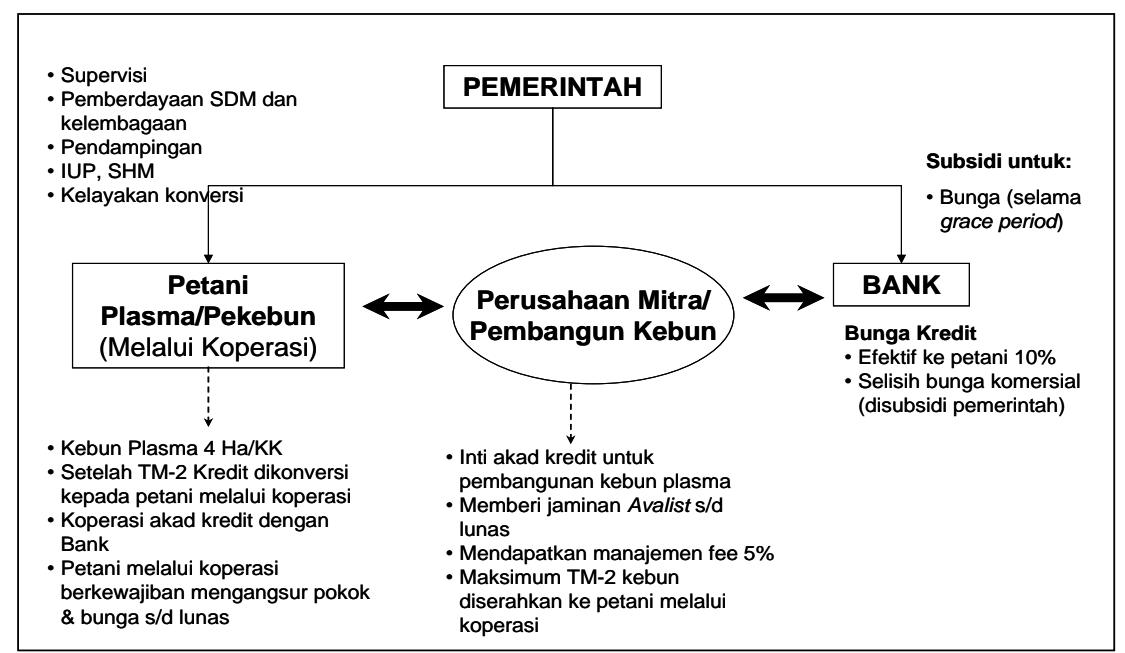

Gambar 1. Skim Kredit KPEN-RP Pola Kemitraan

Sumber: BRI, 2007

Alur Proses KPEN-RP

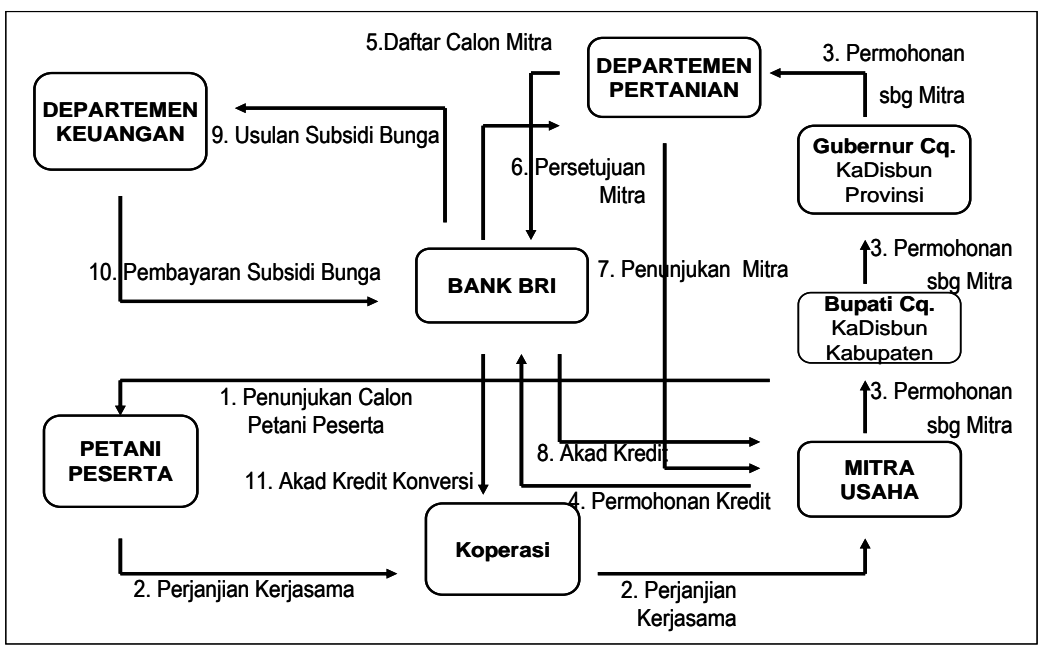

Gambar 2. Alur Proses KPEN-RP Pola Kemitraan

Sumber: BRI, 2007 


\section{Pola Non Kemitraan}

\section{$>$ Skim Kredit KPEN-RP}

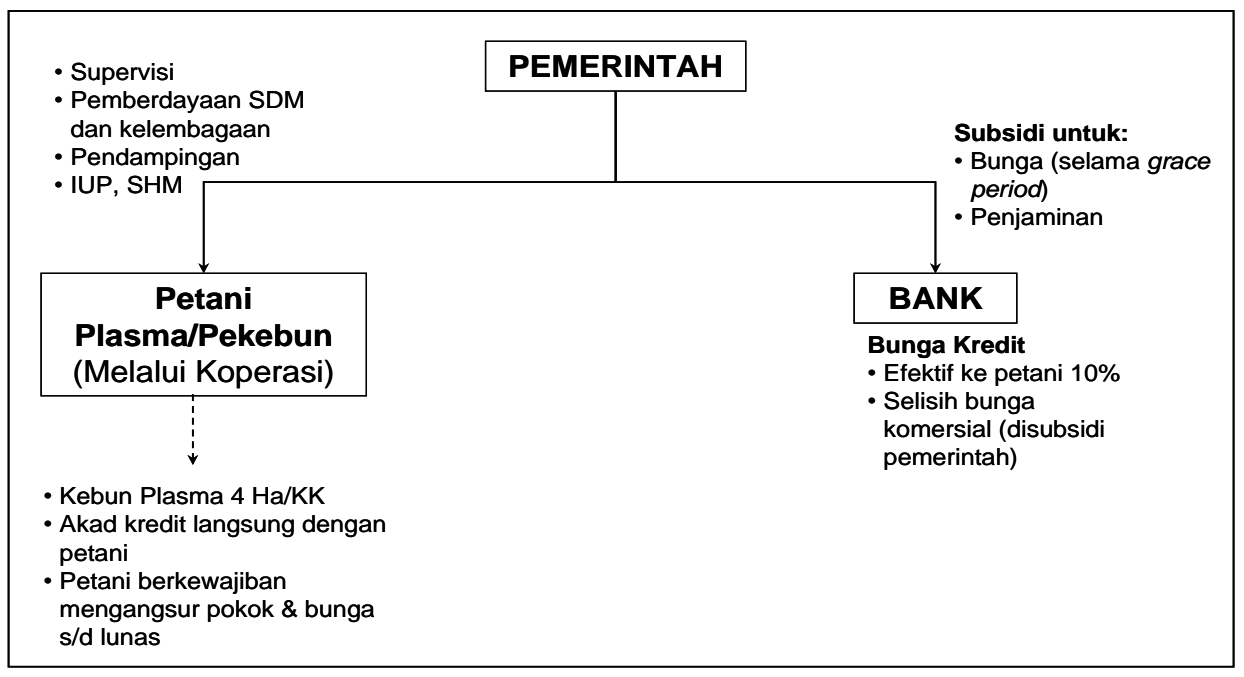

Gambar 3. Skim KPEN-RP Pola Non Kemitraan

Sumber: BRI, 2007

\section{Alur Proses KPEN-RP}

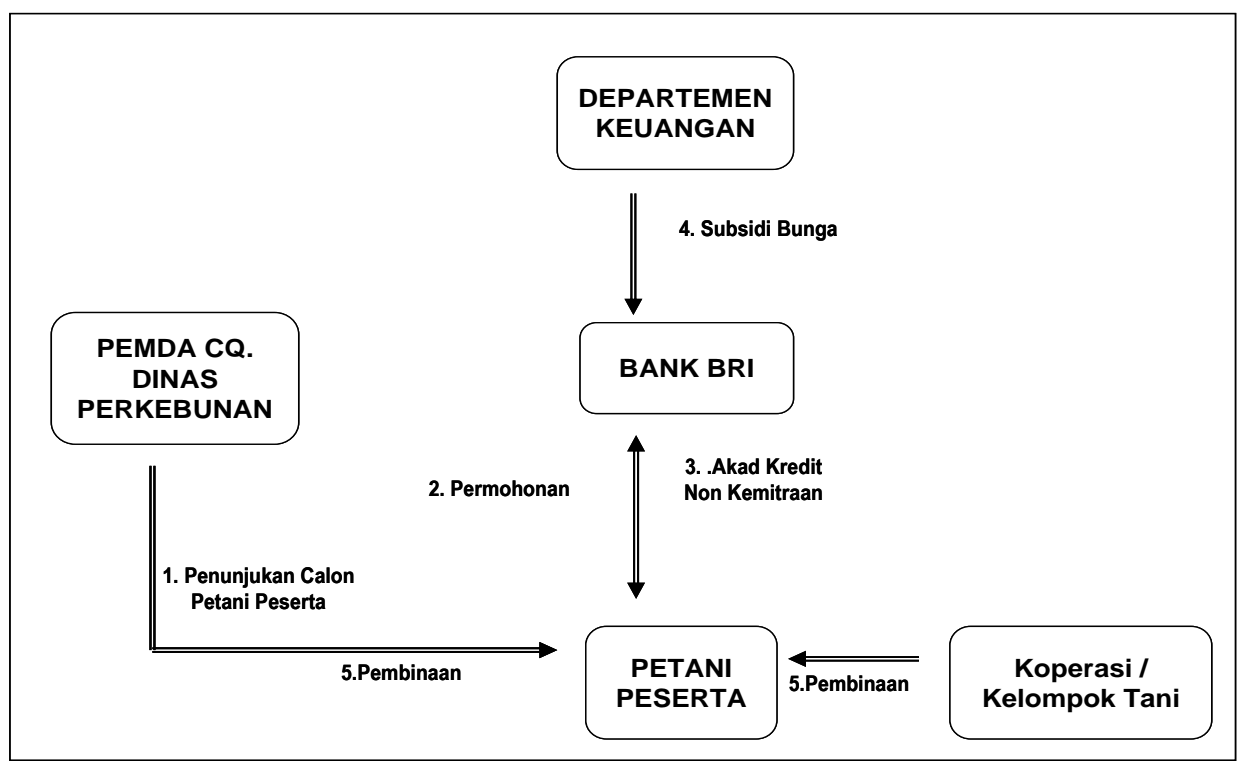

Gambar 4. Alur Proses KPEN-RP Pola Non Kemitraan

Sumber: BRI, 2007

\section{Agunan}

\section{- Agunan Pokok :}


Agunan pokok Proyek perkebunan yang dibiayai KPEN-RP berupa sertifikat hak milik (SHM) atau bukti kepemilikan lainnya (seperti girik, petok, letter C, surat keterangan walinagari) yang dapat ditingkat menjadi sertifikat, dan atau

\section{- Agunan Tambahan lainnya :}

$\checkmark$ Avalis perusahaan mitra s/d kredit lunas (khusus Kemitraan)

$\checkmark$ Agunan aktiva lainnya bila ada

$\checkmark$ Dijamin Pemerintah melalui lembaga penjaminan bila memungkinkan (karet \& kakao)

\section{Syarat dan ketentuan POLA KEMITRAAN}

\section{Peminjam}

- Masa Pembangunan Kebun s/d TM-2 $\rightarrow \rightarrow$ Peminjam: Perusahaan Mitra

- Setelah Masa Konversi (TM-3 dst...) $\rightarrow \rightarrow$ Peminjam: Koperasi mewakili Petani

\section{Syarat Petani/Pekebun}

1. Sebagai anggota koperasi atau kelompok tani

2. Berdomisili disekitar kebun, dibuktikan dengan KTP, KK

3. Harus terdaftar dlm daftar nominatif peserta KPEN-RP yang ditetapkan oleh Bupati/Walikota

4. Berusia diatas 21 Th atau sudah menikah.

5. Tidak memiliki tunggakan kredit

6. Membuat surat kuasa permohonan pembiayaan kepada Koperasi/Perusahaan Mitra

7. Bersedia mengikuti petunjuk pembinaan koperasi/perusahaan mitra/instansi terkait

\section{Syarat Perusahaan Mitra}

1. Memiliki perijinan dan legalitas lengkap

2. Berpengalaman

3. Harus memberi jaminan Avalis 
4. Memiliki Kebun inti dan atau unit pengolahannya

5. Menyerahkan Laporan keuangan audited

6. Tdk termasuk daftar hitam \& daftar pinjaman macet $\mathrm{BI}$

7. Memiliki perjanjian kerjasama dengan Petani/Koperasi, diketahui oleh Bupati/ Walikota (cq. Dinas Perkebunan)

8. Membuat permohonan pinjam ke Bank atas nama Koperasi/Petani disertai daftar nominatif petani KPEN-RP yang ditetapkan oleh Bupati/Walikota

9. Ditetapkan sebagai perusahaan mitra oleh Ditjen Perkebunan atau Bupati/Walikota (cq. Dinas Perkebunan) setelah ada kepastian PTK dari Bank

\section{Syarat Koperasi}

1. Koperasi Primer sudah berbadan hukum

2. Memiliki perijinan dan legalitas lengkap

3. Berpengalaman

4. Tdk termasuk Daftar Hitam \& Daftar Pinjaman Macet BI

5. Tidak memiliki tunggakan kredit

6. Memiliki perjanjian kerjasama dengan Perusahaan Mitra

7. Daftar jumlah anggota pekebun yang akan dibiayai maksimal 500 anggota/KK per koperasi

8. Membuat surat kuasa permohonan pembiayaan kepada Perusahaan Mitra

\section{Tatacara Pengajuan Kredit}

1. Permohonan kredit diajukan oleh Perusahaan Mitra ke Divisi Agribisnis KPBRI setelah mendapatkan kuasa dari Petani melalui Koperasi

2. Permohonan pinjaman dilampiri dengan dokumen pendukung, antara lain :

a. Laporan keuangan perusahaan mitra 2 (dua) tahun terakhir

b. Proposal/study kelayakan proyek

c. Rencana penarikan dan pengembalian kredit.

d. Perjanjian kerjasama antara mitra usaha dengan koperasi/petani peserta. 
e. Bukti perijinan dan legalitas perusahaan mitra dan koperasi

f. Perjanjian Kerjasama antara Perusahaan Mitra dan Koperasi/Petani diketahui Bupati/Walikota

g. Berita Acara Rapat anggota koperasi sebagai surat persetujuan anggota kepada pengurus koperasi untuk mengajukan permohonan kredit bersama-sama dengan Perusahaan Mitra

h. Surat Kuasa dari anggota koperasi kepada pengurus koperasi bersama-sama Perusahaan Mitra untuk mengurus kredit s/d lunas

i. Daftar pengurus Koperasi

j. Daftar nominatif petani yang telah ditetapkan oleh Bupati/Walikota cq. Dinas yang membidangi Perkebunan.

\section{POLA NON KEMITRAAN}

\section{Peminjam}

- Peminjam Petani Langsung

\section{Syarat Petani/Pekebun}

1. Sebagai anggota koperasi atau kelompok tani

2. Memiliki kartu identitas: KTP, KK, Kartu Angota Koperasi

3. Harus ditetapkan oleh Bupati/Walikota (cq. Dinas Perkebunan)

4. Berusia diatas 21 Th atau sudah menikah

5. Tidak memiliki tunggakan kredit

6. Membuat surat permohonan pembiayaan ditujukan langsung kepada Kantor Cabang BRI

7. Bersedia mengikuti petunjuk pembinaan koperasi/perusahaan mitra/instansi terkait.

\section{Tatacara Pengajuan Kredit}

1. Permohonan kredit dapat ditujukan ke: Kantor Cabang.

2. Permohonan pinjaman dilampiri dengan dokumen pendukung, antara lain : 
a. Surat penetapan calon petani peserta dari Bupati/Walikota cq. Dinas yang membidangi perkebunan.

b. Rencana penarikan dan pengembalian Kredit.

c. Identitas lengkap berupa foto copy KTP dan KK.

d. Copy bukti kepemilikan agunan.

\subsubsection{Kebijakan di daerah berkaitan dengan HGU Perkebunan}

Pemberian HGU terkait dengan pembangunan regional, bidang usaha yang dilakukan di atas tanah HGU amat bervariasi dan berbeda pada setiap daerah:

- di Gorontalo antara lain penanaman tumpang sari yakni jagung, kacang, sebagian untuk peternakan, dan saat ini jagung menjadi komoditas andalan sedangkan komoditas jenis usaha perkebunan lainnya adalah perkebunan kelapa, dari sisi permodalan pemegang HGU pada umumnya berasal dari PMDN.

- Komoditas unggulan perkebunan di Jambi adalah kelapa sawit yang kedua karet, demikian halnya di Riau, dan Kalimantan Timur.

- Di Sumatera Utara, sebelumnya jenis komoditas unggulan untuk perkebunan adalah tebu dan tembakau, namun saat ini trend usaha perkebunan sudah bergeser sehingga komoditas unggulan pertama adalah kelapa sawit, yang kedua karet, kemudian kakao dan terakhir tebu.

- Di Provinsi Bali, komoditas unggulan saat ini adalah kelapa,kopi, jambu mete dan untuk tambak, sedangkan perkebunan kapuk menjadi kurang produktif karena kurangnya permintaan pasar.

Adanya kewajiban perusahaan perkebunan membangun kebun untuk masyarakat sekitar sesuai dengan Peraturan Menteri Pertanian Nomor. 26/Permentan/OT.140/2/2007 sampai saat ini belum dilaksanakan. Di Gorontalo bentuk pembangunan kebun untuk masyarakat yang dilaksanakan adalah pola bagi hasil terhadap tanaman tumpang sari. Luas yang diberikan 1-2 ha dalam bentuk bagi hasil yang diikat dengan surat pernyataan bahwa penggarap hanya menanam bukan menguasai tanah tersebut.

Kebijakan daerah mengenai HGU secara khusus tidak ada, yang ada berupa:

- kebijakan umum dalam bentuk layak atau tidaknya HGU tersebut diperpanjang. Hal tersebut dituangkan dalam bentuk rekomendasi. Kebijakan tersebut berkait erat dengan perobahan tata ruang daerah.

- Kebijaksanaan dan prosedur pemberian Izin Usaha Perkebunan di Kabupaten Kutai Kertanegara 
- Adanya Perda yang mengatur tentang pemungutan fee untuk setiap hasil perkebunan di Sumatera Utara

\subsubsection{Peraturan-peraturan lain yang berhubungan dengan Penyelesaian sengketa HGU antara lain :}

1). Undang Undang No. 28 Tahun 1956 tentang Pengawasan Terhadap Pemindahan Hak Atas Tanah Perkebunan (Lembaran Negara Tahun 1956 No 73, Tambahan Lembaran Negara No. 1125).

2). Undang Undang No 29 Tahun 1956 tentang Peraturan-peraturan dan Tindakantindakan mengenai Tanah-Tanah Perkebunan (Lembaran Negara Tahun 1956 No. 74, Tambahan Lembaran Negara No 1126).

3). $\quad$ Pasal 3 Undang-Undang No. 29 Tahun 1956.

4). Surat Edaran dari Menteri Agraria No. Sekra 9/2/4 tanggal 4 Mei 1962, menyebutkan beberapa kebijaksanaan yakni :5)

a. Tanah Perkebunan/Kehutanan dan tanah-tanah lain yang langsung dikuasai oleh Negara yang telah dipakai untuk kepentingan Pemerintah misalnya untuk perluasan kota, bangunan pemerintah, lapangan olah raga untuk umum dan sesamanya itu supaya tetap terjamin.

b. Tanah-tanah perkebunan dan lain-lainnya yang dikuasai langsung oleh Negara yang telah diduduki rakyat untuk perumahan/ perkampungan agar tetap terjamin baikpun perumahan/ perkampungan itu tetap ditempat masing-masing, maupun dikelompok-kelompok demikian rupa hingga merupakan perkampungan yang teratur baik, dengan usaha penukaran/ penggantian tanah yang lain agar komplek tersebut tidak terganggu satu sama lain.

c. Tanah-tanah perkebunan/kehutanan dan tanah-tanah lain yang langsung dikuasai oleh Negara yang telah dipakai rakyat untuk tanah pertanian terutama yang ditanami bahan makanan, jangan diadakan perobahan sebelum tanamannya dipanen; apabila tanah-tanah tersebut memang masuk rencana perluasan perkebunan/kehutanan lagi, maka pelaksanaannya agar ditempuh jalan kebijaksanaan melalui musyawarah antara pihak-pihak yang bersangkutan untuk membentuk unit-unit yang ekonomis bagi perkebunan/kehutanan dan untuk mencarikan kemungkinan tempat-tempat lain bagi rakyat.

d. Tanah-tanah perkebunan/kehutanan dan tanah-tanah lain yang dikuasai langsung oleh Negara dan telah digarap oleh rakyat, lagipula tidak akan dipergunakan oleh pemerintah cq. instansi yang berkepentingan, pada dasarnya akan dijadikan tanah pertanian dan dibagikan kepada rakyat yang mengerjakan sendiri tanah-tanah tersebut demi untuk meningkatkan produksi pertanian rakyat sambil memperbaiki sosial ekonominya. 
e. Mengingat hal yang tersebut pada ayat d) diatas perlu meninjau kembali areal tanah-tanah yang dipakai oleh instasi perkebunan/ kehutanan agar semua tanah penggunaannya (land-use) dilakukan secara tepat dan sesuai dengan kepentingan Nasional.

5). PP. 22 Tahun 1961 tentang pelaksanaan pembagian tanah dan pemberian ganti rugi.

6). Peraturan Menteri Negara Agraria/Kepala Badan Pertanahan Nasional No. 9 Tahun 1999 tanggal 14 Oktober 1999 Tentang Tata Cara Pemberian dan Pembatalan Hak Atas Tanah Negara dan Hak Pengelolaan.

7). Peraturan Pemerintah Republik Indonesia No. 36 Tahun 1998 Tanggal 5 Maret 1998 Tentang Penertiban dan Pendayagunaan tanah Terlantar.

Pasal 5 (1) : Tanah Hak Guna Usaha tidak dipergunakan sesuai dengan keadaannya atau sifat dan tujuan haknya sebagimana dimaksud dalam pasal 3, apabila tanah itu tidak diusahakan sesuai dengan kriteria pengusahaan tanah pertanian yang baik sesuai ketentuan perundang-undangan yang berlaku.

Ayat (2). Jika Hanya sebagian bidang tanah HGU sebagaimana dimaksud pada ayat 1 memenuhi kriteria terlantar, maka hanya bahagian tanah tersebut yang dapat dinyatakan terlantar.

8). Keputusan Menteri Negara Agraria/Kepala Badan Pertanahan Nasional No. 21 Tahun 1994 Tentang Tata Cara Perolehan Tanah bagi Perusahaan Dalam Rangka Penanaman Modal $\rightarrow$ Pasal 25 Perpanjangan Hak Guna Usaha $\rightarrow 25$ Tahun.

9). Instruksi Menteri Negara Agraria/KBPN No. 2 Tahun 1999 tanggal 27 Januari 1999 Tentang Percepatan Pelayanan Pendaftaran Peralihan Hak Atas Tanah.

10). Instruksi Menteri Negara Agraria/KBPN No. 5 Tahun 1999 tanggal 12 Mei Tentang Inventarisasi Tanah-Tanah Hak Guna Usaha yang dijarah masyarakat dan pembinaannya.

11). Peraturan Pemerintah Republik Indonesia No. 40 Tahun 1996 Tanggal 17 Juni 1996 Tentang Hak Guna Usaha, Hak Guna Bangunan dan Hak Pakai Atas Tanah.

12). Permenag/Kepala BPN No 5 Tahun 1999 jo. Surat Edaran BPN Tanggal 9 November 2000 No. 500 - 3394 KBPN Tentang Pedoman Penyelesaian Hak Ulayat.

13). dll.

\subsubsection{Peran Panitia B}

Peran Panitia B dalam pemberian HGU adalah memperhatikan apakah syarat-syarat sudah dipenuhi oleh pemohon HGU sesuai dengan aturan yang berlaku dan tidak ada 
konflik dilapangan.. Dari enam Provinsi Sampel, Panitia B menolak pemberian HGU karena berbagai alasan seperti :

- Adanya konflik penguasaan dengan penggarap atau adanya klaim dari masyarakat, sehingga tidak bisa diadakan pengukuran, hal ini terjadi di Gorontalo dan Jambi.

- Sebagian wilayah yang dimohonkan HGU masuk dalam kawasan Budidaya Kehutanan(KBK)

- Sebagian wilayah yang dimohonkan HGU masuk dalam kawasan pertambangan

Yang masuk dalam Panitia B adalah Kepala Dinas Kehutanan, sebenarnya yang paling mengetahui kondisi teknis dilapangan termasuk yang menentukan kawasan hutan adalah Balai Pemanfaatan Kawasan Hutan (BPKH). Untuk mengantisipasi tanah yang dimohonkan HGU masuk dalam kawasan kehutanan, setiap permohonan HGU harus menyertakan rekomendasi yang menyatakan bahwa daerah itu masuk Arela Penggunaan Lain (APL).

\subsection{Identifikasi Tanah HGU}

\subsubsection{Data HGU di BPN Pusat}

Berdasarkan data Badan Pertanahan Nasional, pada Tahun 2001 luas perkebunan rakyat dan perkebunan skala besar di Indonesia sekitar 14,45 juta hektar atau sekitar $7,58 \%$ luas wilayah Indonesia. Sebagian besar perkebunan itu terdapat di Sumatera dengan luas sekitar 9,76 juta hektar atau sekitar $67,55 \%$ total perkebunan. Jawa dan Bali hanya seluas 690270 hektar atau sekitar 4,71\% total perkebunan.

Dari luas perkebunan itu, sekitar 4,56 juta hektar $(31,53 \%)$ adalah HGU dan lainnya adalah perkebunan rakyat $(68,47 \%)$. Penyebaran HGU yang terluas adalah di Sumatera, yaitu 2,38 juta hektar (24,42 \% luas perkebunan). Di Jawa, walaupun luasnya hanya sekitar 0,60 juta hektar, namun sebagian besar $(87 \%)$ merupakan perkebunan skala besar dengan $1108 \mathrm{HGU}$ (45\% total perusahaan HGU) Keadaan yang digambarkan pada Tabel 4-1 itu, menunjukkan bahwa perkebunan yang merupakan komoditi strategis itu, potensinya menyebar tidak merata, demikian pula perusahaan HGUnya.

Tabel 4.2.1: Luas Perkebunan dan HGU Perkebunan Menurut Wilayah

\begin{tabular}{|c|c|c|c|c|c|c|c|}
\hline \multirow[t]{2}{*}{ No } & \multirow[t]{2}{*}{ Wilayah } & \multirow{2}{*}{$\begin{array}{l}\text { Luas } \\
\text { Wilayah } \\
\text { (Ha) }\end{array}$} & \multicolumn{2}{|c|}{ Luas Perkebunan } & \multicolumn{3}{|c|}{ Luas HGU Perkebunan } \\
\hline & & & $\mathrm{Ha}$ & $\begin{array}{l}\% \\
\text { Perke- } \\
\text { bunan }\end{array}$ & $\mathrm{Ha}$ & $\begin{array}{l}\% \\
\text { HGU }\end{array}$ & $\begin{array}{l}\% \\
\text { Perke } \\
- \\
\text { buna } \\
\mathrm{n}\end{array}$ \\
\hline
\end{tabular}




\begin{tabular}{|c|c|c|c|c|c|c|c|c|}
\hline 1 & Sumatera & $\begin{array}{c}47 \\
730\end{array}$ & 339 & $\begin{array}{cc}9 & 763 \\
280 & \end{array}$ & 67,55 & $\begin{array}{cc}2 & 383 \\
834 & \end{array}$ & 52,31 & 24,42 \\
\hline 2 & Jawa dan Bali & $\begin{array}{c}13 \\
370\end{array}$ & 337 & $\begin{array}{l}690 \\
270^{690}\end{array}$ & 4,71 & 598687 & 13,14 & 86,73 \\
\hline 3 & Kalimantan & $\begin{array}{c}53 \\
270\end{array}$ & 629 & $\begin{array}{l}2^{614} \\
270^{6}\end{array}$ & 4,25 & 502980 & 11,04 & 81,88 \\
\hline 4 & Sulawesi & $\begin{array}{c}19 \\
310\end{array}$ & 614 & $\begin{array}{cc}1 & 944 \\
040 & \end{array}$ & 13,45 & 246811 & 5,42 & 12,70 \\
\hline 5 & $\begin{array}{l}\text { Nusa } \\
\text { Tenggara dan } \\
\text { Maluku }\end{array}$ & $\begin{array}{c}15 \\
120\end{array}$ & 323 & $\begin{array}{cc}1 & 244 \\
010 & \end{array}$ & 8,61 & 806750 & 17,70 & 64,85 \\
\hline 6 & Papua & $\begin{array}{c}41 \\
010\end{array}$ & 480 & $880^{197}$ & 1,37 & 17802 & 0,39 & 9,00 \\
\hline & Indonesia & $\begin{array}{l}190 \\
810\end{array}$ & 923 & $\begin{array}{ll}14 & 453 \\
750 & \end{array}$ & 100,00 & $\begin{array}{ll}4 & 556 \\
863 & \end{array}$ & $\begin{array}{l}100,0 \\
0\end{array}$ & 31,53 \\
\hline
\end{tabular}

Sumber: Himpunan Pidato Kepala BPN, 2001

\subsubsection{Data HGU di Provinsi}

Dari 6 provinsi lokasi sampel menunjukkan luasan HGU yang terbesar ada di Sumatera Utara dengan luas 1061718,503 ha $(36,46 \%)$ yang sebagian besar ditanami kelapa sawit, karet, tebu dan campuran tebu, coklat dan teh. Luas HGU yang maximal pernah diberikan juga ada di Sumatera Utara yaitu 26000,0000 ha. Setelah Sumatera Utara, adalah Riau yang mempunyai luas HGU sebesar 909429,47 ha (31,23 \%) dan sebagian besar ditanami kelapa sawit dan kemudian karet.

Kalimantan yang mempunyai luas wilayah terbesar, luasan HGU nya lebih kecil dari Riau yaitu sebesar 739998,613 ha $(25,41 \%)$ yang penggunaannya untuk perkebunan kelapa sawit, karet, jeruk dan lada. Provinsi Jambi berada di bawah Kalimantan Timur dengan luas sebesar 187881,04 ha $(6,45 \%)$ dengan komoditas unggulan yang sama yaitu kelapa sawit dan karet, kemudian Gorontalo dengan luas Hak Guna Usaha sebesar 10794,9438 ha $\quad(0,37 \%)$ dengan penggunaan tanahnya sebagian besar untuk kelapa dan terakhir adalah Provinsi Bali dengan luas HGU sebesar 2 417,4814 ha $(0,08 \%)$ yang penggunaan tanahnya untuk kelapa, kapuk, kopi dan jambu mete .

Adapun batas maximum dan minimum yang pernah diberikan oleh masing-masing provinsi bervariasi, dalam peraturan batas minimum luas HGU yang dapat diberikan adalah 5 ha, dari 6 provinsi sampel batas minimum luasan HGU yang pernah diberikan 
ada di Gorontalo yaitu seluas 11.1000 ha. Sedangkan batas maximum luasan HGU yang pernah diberikan ada di Provinsi Sumatera Utara yaitu seluas 26000,0000 ha.

Untuk HGU yang sudah berakhir dan belum atau tidak diperpanjang paling banyak berada di Gorontalo yaitu sebesar 111 bidang dengan luasa 5855,2868 ha, dan yang seluruh HGU nya sudah diperpanjang atau diperbarui hanya ada di Provinsi Kalimantan Timur.

Tabel 4.2.2 Data HGU Provinsi

\begin{tabular}{|c|c|c|c|c|c|c|}
\hline \multirow[t]{2}{*}{ No. } & \multirow[t]{2}{*}{ Provinsi } & \multirow{2}{*}{$\begin{array}{l}\text { Luas HGU } \\
\text { (ha) }\end{array}$} & \multicolumn{2}{|c|}{ Batas luas (ha) } & \multicolumn{2}{|c|}{ Berakhir } \\
\hline & & & $\max$ & $\min$ & bdg & Luas(ha) \\
\hline 1. & Jambi & 187881,04 & 6,220 & 11,6 & - & - \\
\hline 2. & Gorontalo & 10794,9438 & 587,5885 & 11.1000 & 111 & 5855,2868 \\
\hline 3. & Riau & 909429,47 & 14,650 & 17.81 & 4 & 1,555 \\
\hline 4. & $\begin{array}{l}\text { Kalimantan } \\
\text { Timur }\end{array}$ & 739998,613 & $22,587.000$ & 93.916 & - & - \\
\hline 5. & $\begin{array}{l}\text { Sumatera } \\
\text { Utara }\end{array}$ & 1061718,503 & 26000,0000 & 8,1100 & 16 & 39499,8026 \\
\hline 6. & Bali & 2417,4814 & 1128,9500 & 2,2060 & 8 & 1557,1944 \\
\hline & Jumlah & 2912240,051 & & & & \\
\hline
\end{tabular}

Sumber: Kantor Wilayah BPN Prov. 2007, Diolah

\subsubsection{Data HGU di Kabupaten/Kota}

Dari 6 kabupaten yang dijadikan sampel, luasan HGU yang terbesar berada di Kabupaten Deli Serdang yaitu 127977,0626 ha (76 \%), menyusul kemudian Muaro Jambi seluas 36781,527 ha $(21,87 \%)$, Gorontalo seluas 2160,1744 ha (1,3\%), Buleleng sebesar 962,4554 ha $(0,6 \%)$, Kutai Kartanegara seluas 216,568.946 ha ( $0,13 \%)$ dan Kampar seluas 115,772.75 ha ( 0,07\%).

Batas maksimum dan minimum luas tanah HGU yang pernah diberikan dari 6 provinsi sampel batas maximum luasan HGU yang pernah diberikan ada di Muaro Jambi seluas 6938 ha, disusul Deli Serdang yaitu seluas 4146,8500 ha, Buleleng seluas 488,0550 ha, Gorontalo seluas 198,3795 ha, Kutai Kartanegara seluas $19,986.700$ ha dan terakhir Kabupaten Kampar seluas 14,538.089 ha. Sedangkan batas minimum luasan HGU yang pernah diberikan ada di Kabupaten Kampar yaitu 17.81 ha, Kutai 
Kartanegara seluas 21 ha dan Muaro Jambi seluas 25 ha, ketiganya merupakan HGU Perorangan.

Batasan luas maksimum untuk tanah yang dapat diberikan dengan HGU untuk badan hukum secara tidak langsung telah diatur dalam Peraturan Menteri Negara Agraria/Kepala Badan Pertanahan Nasional No. 2 Tahun 1999 tentang Izin Lokasi. Luas tanah yang akan diberikan Hak Guna Usaha tidak dapat melebihi luas izin lokasi yang diberikan. Untuk satu perusahaan dan perusahaan-perusahaan lain yang satu "group" perusahaan tersebut:

Untuk perkebunan dibedakan, komoditas tebu max untuk satu provinsi seluas 60.000 ha dan 150.000 ha seluruh Indonesia dan untuk komoditas lainnya satu provinsi 20.000 ha dan 100.000 ha untuk seluruh Indonesia. Faktanya, perusahaan meminta HGU secara bertahap seperti PT Rea Kaltim yang memiliki HGU lebih dari 100.000 ha di Provinsi Kalimantan Timur mengajukan permohonan HGU secara bertahap, dan jika terjadi kelebihan luas dari yang seharusnya diperoleh digunakan oleh anak perusahan PT Rea Kaltim.

Tabel 4.2.2 Data HGU Kabupaten

\begin{tabular}{|l|l|l|l|l|l|l|}
\hline No. & Kabupaten & Luas HGU & \multicolumn{2}{l|}{ Batas luas(ha) } & \multicolumn{2}{l|}{ berakhir } \\
\cline { 4 - 7 } & & & max & min & bdg & Luas(ha) \\
\hline 1. & Muaro Jambi & 36781,527 & 6938 & 25 & - & - \\
\hline 2. & Gorontalo & 2160,1744 & 198,379 & 7,6538 & 66 & 3346,199 \\
& & & 5 & & & 7 \\
\hline 3. & Kampar & $115,772.75$ & $\begin{array}{l}14,538.0 \\
89\end{array}$ & 17.81 & - & - \\
\hline 4. & Kutai Kertanegara & $216,568.946$ & $19,986.7$ & 21 & - & - \\
& & & 00 & & & \\
\hline 5. & Deli Serdang & 127977,0626 & 4146,85 & 8,1100 & 5 & 10278,00 \\
& & & 00 & & & 26 \\
\hline 6. & Buleleng & 962,4554 & 488,055 & 47,210 & 7 & 1450,510 \\
& & & 0 & 0 & & 4 \\
\hline & Jumlah & $\begin{array}{l}168213,560 . \\
696\end{array}$ & & & & \\
\hline
\end{tabular}

Sumber: Kantor Wilayah BPN Prov. 2007, Diolah 
Sebaran HGU di enam Provinsi sampel, tiga kabupaten yang terbesar HGU nya adalah :

a) Jambi

- Kab. Batanghari 46.526,13 ha

- Kab. Muaro Jambi $36.781,527$ ha

- Kab. Tanjab Barat 28.453,3 ha

b) Gorontalo

- Kab. Gorontalo 6094,7266 ha

- Kab Boalemo 2311,3888 ha

- Kab. Pohuwatu 2346,2256 ha

c) Riau

- Kab. Rokan Hilir $164,442.21$ ha

- Kab. Pelalawan 160,431.81 ha

- Kab. Indragiri Hilir 156,483.64 ha

d) Kalimantan Timur

- Kab. Kutai Kartanegara 216,568.946 ha

- Kab. Kutai Timur 165,997.250 ha

- Kab. Pasir 124,078.110 ha

e) Sumatera Utara

- Kab. Labuhan Batu 301018,5400 ha

- Kab. Asahan 155037,2930 ha

- Kab. Langkat 129790,9225 ha

f) Bali

- Kab. Jembrana 1246,6860 ha

- Kab. Buleleng 962,4554 ha 
- Kab. Karangasem 171,8000 ha

Penggunaan/pemanfaatan tanah HGU sebagian besar mengalami perubahan mengikuti trend perkebunan yang ada seperti yang terjadi di Gorontalo, penggunaannya dimanfaatkan dalam bentuk perkebunan kelapa pada awalnya, sekarang selain kelapa, terjadi penanaman semusim (tumpang sari) yang ditanami dengan jagung, bahkan jagung saat ini menjadi komoditi unggulan di Gorontalo. Demikian juga yang terjadi di Sumatera Utara, awalnya perkebunan didominasi oleh tanaman tebu, karet juga kakao, namun saat ini sudah beralih ke tanaman kelapa sawit. Sedangkan di Bali, perubahan penggunaan terjadi karena berbagai faktor seperti di Buleleng, awalnya ditanami kapuk kemudian menjadi tanaman kelapa karena kurangnya permintaan pasar terhadap kapuk dan adanya perubahan RTRW yang menjadikan daerah perkebunan tersebut menjadi kawasan wisata dan di Klungkung tanah HGU yang dijadikan tambak sudah hilang karena terjadi abrasi.

\subsubsection{Permasalahan di atas tanah HGU}

Hasil pengumpulan data di 6 provinsi sampel menunjukkan banyaknya konflik tanah HGU, antara lain :

a) Di Provinsi Bali, khususnya di Kabupaten Buleleng banyak konflik HGU, seperti adanya tanah HGU yang telah habis masa berlakunya, namun belum diajukan permohonan perpanjangan hak, karena terjadi perebutan penguasaan tanah tersebut antara Pemerintah Provinsi Bali, Pemerintah Kabupaten Buleleng, perusahaan/badan hukum dan masyarakat sekitar.

- HGU Nomor 1/Desa Pemuteran seluas 246,5000 ha tidak diperpanjang oleh PT Margarana karena adanya surat Bupati kepada Kepala Kantor Pertanahan tanggal 5 Agustus 2003 yang isinya meminta Kepala Kantor Pertanahan Buleleng untuk tidak menyetujui permohonan perpanjangan HGU yang dikuasai oleh PT Margarana, hal ini beralasan karena ditinjau dari segi produktivitas hasil tanaman kelapa dan kapuk kurang berhasil karena dari 9.233 pohon kelapa hanya menghasilkan kelapa sebanyak 111.069 butir per tahun dan kapuk hanya menghasilkan 12 ton per tahun, kemudian lokasi perkebunan tersebut sesuai dengan Rencana Umum Tata Ruang Wilayah tersebut ditetapkan sebagai kawasan wisata. Kondisi fisik dilapangan tanah perkebunan tersebut sebagian sudah dikuasai oleh masyarakat baik eks pekerja perkebunan maupun masyarakat disekitar lokasi secara liar. Dari sisi pemanfaatannya untuk perkebunan kelapa dan kapuk yang sesuai hanya seluas 61,63 ha atau 25 $\%$ sedangkan pemanfaatan yang tidak sesuai seluas 187,87 ha atau $75 \%$ meliputi pemukiman dan areal pertanian rakyat.

- HGU Nomor 1/Desa Sumberklampok atas nama PT Darma Jati dan HGU Nomor 2 dan 3/Desa Sumberklampok atas nama PT Margarana, Kondisi 
fisik dilapangan tanah perkebunan tersebut dipergunakan untuk perumahan yang ditata dengan baik dan dekat dengan jalan raya, dari tahun 1992 pihak perkebunan tidak pernah menerima hasil karena sebagian besar kelapa tidak berbuah

b) Di Provinsi Gorontalo

Pada tahun 2006 dilakukan inventarisasi tanah HGU dan hasilnya ada 7 pemegang HGU yang bermasalah dengan petani yaitu:

1. PT Ayula(Kab.Gorontalo)

- Bahwa sertipikat HGU No. 03/Molowahu dengan luas 107,015 ha akan berakhir pada tahun 2008

- Bahwa telah terjadi penguasaan lahan turun temurun oleh penggarap sejak tahun 1980 sehingga masyarakat menolak HGU tersebut diperpanjang.

- Bahwa sebagian lahan tersebut terjadi perubahan penggunaan yang dulunya kelapa telah berubah dan ditanami jagung, kacang.

- Bahwa luas yang dikuasai oleh masing-masing penggarap \pm 1 ha sehingga sisa luas yang dikuasai oleh pemilik HGU adalah \pm 33 ha.

2. PT Molamahu, Umar hadji Kasim, Jarin K. Muhammad dan Hj. Nurjanah(Kab. Gorontalo)

- sertipikat HGU No. 01/Molowahu dengan luas 24,83 ha, HGU No. 2/Molowahu dengan luas 24,83 ha, HGU No. 3/Molowahu dengan luas 24,83 ha, HGU No. 4/Molowahu dengan luas 24,88 ha dengan luas keseluruhan 99,37 ha yang akan berakhir pada 31 Desember 2006.

- Bahwa telah terjadi penguasaan lahan turun temurun oleh penggarap sejak tahun 1974, sebagian lahan tersebut merupakan milik penggarap yang dipinjamkan lepada Sdr. Umar ají kasim Cs pada tahun 1976, pada tahun 1981 kemudian diterbitkan sertipikat HGU, dan sampai Semarang pemilik HGU tidak dapat menduduki lokasi tersebut, sebagian lokasi telah dikuasai penggarap.

- Sebagian lahan tersebut terjadi perubahan penggunaan yang dulunya merupakan lahan peternakan telah berubah menjadi tanaaman jagung, kacang dan sebagian kelapa.

- Bahwa luas yang dikuasai oleh masing-masing penggarap $\pm 1,5$ ha s/d 2 ha sehingga sisa luas yang dikuasai oleh pemilik HGU hádala 11,5 ha. 
3. PT. Buntula Tapadaa (kab. Boalemo)

- Bahwa sertipikat HGU No. 8/Limboto dengan luas 113.687 ha berakhir pada tahun 2005 dan sampai sekarang belum ada permohonan perpanjangan HGU

- Bahwa lokasi HGU tersebut telah terjadi pembagian ahli waris dari pemegang HGU, sebagian telah dikuasai oleh penggarap dan Dinas Perkebunan seluas \pm 10 ha tanpa ada komplain dari ahli waris sebagai pemegang HGU.

- Bahwa sebagian tanah tersebut telah dikuasai penggarap sebagian maíz terdapat kelapa, dibawahnya ditanami jagung dan hasilnya dikuasai tanpa ada pembagian hasil lepada pemilik HGU..

- Bahwa luas yang dikuasai oleh masing-masing penggarap $\pm 1,5$ ha s/d 2 ha sehingga sisa luas yang dikuasai oleh pemilik HGU (ahli waris) $\pm 28,87$ ha.

4. PT. Marva (Kab. Gorontalo)

- Bahwa sertipikat HGU No. 01/Puncak dengan luas 29,60 ha berakhir pada tahun 2004 dan sampai sekarang belum ada permohonan perpanjangan HGU

- Bahwa lokasi HGU tersebut sebagian telah dikuasai penggarap dan ditanami jagung, kacang tanpa ada pembagian hasil lepada pemilik HGU.

- Bahwa luas yang dikuasai oleh masing-masing penggarap $\pm 1,5$ ha s/d 2 ha sehingga sisa luas yang dikuasai oleh pemilik HGU \pm 35 ha.

5. PT. Pandan Sari (Kab. Gorontalo)

- Bahwa sertipikat HGU No. 01/Labanu sekarang telah menjadi desa Motilango hasil pemekaran dari desa Labanu dengan luas 47.5607 ha.

- Sertipikat HGU berakhir pada tahun 2001 dan telah diajukan permohonan perpanjangan HGU melalui Kanwil BPN Prov. Sulawesi Utara namun permohonan tersebut tidak pernah direkomendasikan kembali ke kantor Pertanahan kabupaten Gorontalo

- Bahwa lokasi tersebut telah direncanakan pengusulan sebagai obyek landreform pada tahun 2001 namun belum ada penegasannya dari kanwil BPN Prov. Sulawesi Utara dan sampai sekarang belum ada perencanaan lebih lanjut.

- Lokasi HGU tersebut telah dikuasai oleh penggarap, sebagian telah dibangun rumah penduduk permanen dan semi permanen dan ditanami 
jagung, kacang tanpa ada pembagian hasil kepada pemilik HGU, hal itu tidak menimbulkan komplain dari pemilik HGU

- Luas yang dikuasai oleh masing-masing penggarap $\pm 1,5$ ha s/d 2 ha sehingga sisa luas yang dikuasai oleh pemilik $\mathrm{HGU} \pm 5,56$ ha

a. PT Pedago (Kab. Boalemo)

- Bahwa sertipikat HGU No. 04/Dumbula sekarang telah menjadi desa Limbatihu hasil pemekaran dari desa Dumbula dengan luas 132.559 ha.

- Sertipikat HGU berakhir pada tahun 2009

- Lokasi HGU tersebut adalah milik dari Pemda Boalemo (BUMD) dan sampai sekarang sebagian tanah tersebut telah digarap dan diolah oleh masyarakat (penggarap).

- Bahwa pemilik HGU sampai sekarang sudah tidak lagi berada pada lokasi tanah tersebut, sebagian tanah dialokasikan untuk pembangunan koramil dan gedung sekolah

- Luas yang dikuasai oleh masing-masing penggarap $\pm 1,5$ ha s/d 2 ha sehingga sisa luas yang dikuasai oleh pemilik HGU \pm 4 ha pohon kelapa yang masih produktif.

b. Trees Ranti

- Bahwa sertipikat HGU No. 02/Tabongo Barat dengan luas 15.4803 ha akan berakhir pada tahun 2008 dan sampai sekarang belum ada permohonan perpanjangan HGU

- Lokasi HGU tersebut sebagian telah dikuasai oleh penggarap dan ditanami jagung, kacang dari hasil penggarapannya dibagi kepada pemilik HGU berdasarkan kesepakatan pembagian bagi hasil antara pemilik HGU dan masyarakat(penggarap), dan sampai sekarang terdapat perselisihan antara penggarap dan pemilik HGU tentang lokasi garapan

- Luas yang dikuasai oleh masing-masing penggarap $\pm 1,5$ ha s/d 2 ha sehingga sisa luas yang dikuasai oleh pemilik HGU $\pm 0,48$ ha dipergunakan untuk gilingan hasil dari tanaman (sawah).

c) Di Provinsi Jambi, khususnya di Kabupaten Muaro Jambi ada konflik HGU yang sudah habis jangka waktunya antara PT Kemenyan versus masyarakat yang diwakili Pemda. Ex HGU PT Perkebunan Kemenyan yang sudah dibatalkan berdasarkan putusan MA RI dan diserahkan kepada Pemda, tanahnya diokupasi oleh masyarakat, saat ini BPN sedang malakukan pendekatan kepada Pemda untuk menyerahkan tanah tersebut kepada masyarakat melalui Program 
Pembaruan Agraria Nasional. Demikian juga dengan HGU Perorangan atas nama Nona Aisyah, ada yang diokupasi oleh masyarakat dan sekarang sedang dalam proses untuk diberikan kepada masyarakat.

d) Di Provinsi Riau Khususnya Kabupaten Kampar ada konflik antara PT Raja Garuda Mas dengan masyarakat sekitar, yang menjadi permasalahan kalau tanah HGU yang diokupasi oleh masyarakat diserahkan kepada masyarakat, masyarakat akan menuntut dengan hak ulayat.

e) Di Provinsi Kalimantan Timur, khususnya Kabupaten Kutai Kartanegara ada konflik antara PT Hasfarm Produk Ltd dengan masyarakat yang sebagian besar transmigrasi, adanya okupasi masyarakat di dalam dan disekitar tanah HGU, \pm 1000-3000 ha diokupasi masyarakat. Di atas HGU PT Rea Kaltim juga ada okupasi dari masyarakat.

f) Di Provinsi Sumatera Utara banyak sekali konflik dengan masyarakat yang menuntut ganti rugi atas tanah HGU yang diklaim sebagai tanah mereka, memperhatikan volume konflik yang cukup tinggi maka diusulkan untuk membuat edaran yang berisi pedoman atau acuan kriteria tuntutan masyarakat yang bagaimana yang akan diproses untuk ditindak lanjuti, karena selama ini Panitia A yang harus menganalisa setiap konflik/permasalahan yang terjadi.

\subsection{Peranan HGU Perkebunan dalam Pembangunan Ekonomi}

\subsubsection{Gorontalo}

Di Gorontalo, pertanian menjadi motor penggerak kegiatan ekonomi yang masih sulit tergantikan oleh kegiatan usaha lainnya. Dari tahun ke tahun, pertanian selalu memberikan kontribusi terbesar. Tahun 2001, lapangan usaha ini membukukan nilai Rp 398 milyar. Keunggulan sektor pertanian itu membuat kegiatan di industri pengolahan bergairah. Sebab hampir semua bahan baku industri bersumber dari hasil pertanian. Peran industri pengolahan sebagai wahana untuk memberikan nilai tambah menjadi nyata dan penting bagi Kabupaten Gorontalo. Dengan kata lain tidak berlebihan kalau Gorontalo berhasil mengembangkan perekonomian rakyat berbasis agroindustri.

Gorontalo mempunyai puluhan komoditas pertanian hortikultura yang potensial dikembangkan, sebut saja kelapa, cengkeh, padi, jagung, kedelai, kacang tanah, kacang hijau, ubi kayu dan ubi jalar, serta tebu. Beragam komoditas dimiliki seperti menjanjikan masa depan daerah Gorontalo.

Tebu, misalnya, telah lama menjadi tanaman andalan Kabupaten Boalemo. Ratusan hektar tanaman tebu bisa dilihat di wilayah Paguyaman dan Tilamuta. Produksi tebu cukup baik karena petani bisa langsung memasarkan hasil tanamnya ke pabrik gula Rajawali yang sudah ada di Paguyaman selama 20 tahun. Setiap hektar tebu bisa menghasilkan enam ton tebu, sedangkan areal tebu mencapai 796 hektar. 
Dalam peta komoditas pertanian dan perkebunan Gorontalo tahun 2002, kelapa sangat signifikan memberi kontribusi bagi pertumbuhan ekonomi.

Dari sector perkebunan, komoditi yang ditanami terdiri dari :

1. Kelapa : $23.935,13 \mathrm{Ha}$

2. Kakao : $1.399,96 \mathrm{Ha}$

3. Jambu Mente : 451,86 Ha

4. Kapuk : $370,65 \mathrm{Ha}$

5. Kemiri : $414,86 \mathrm{Ha}$

6. Kopi : 490,70 Ha

TANAMAN kelapa yang tersebar merata di wilayah Kabupaten Gorontalo sebenarnya sudah mulai berkurang. Baru sekarang pemerintah kabupaten berniat menggarap potensi yang cukup menjanjikan ini untuk memicu pertumbuhan ekonomi.

Kelapa tumbuh hampir di seluruh kabupaten di provinsi itu. Luas areal kelapa mencapai 60.166 hektar, dengan jumlah produksi per tahun mencapai 70.166 ton. Dari kelapa yang diolah menjadi bungkil dan minyak kelapa kasar, Gorontalo meraup devisa 11,8 juta dollar Amerika Serikat.

PRODUKSI kelapa meningkat sejak tahun 2000. Namun demikian, produksi yang dicapai akhir-akhir ini belum mampu melewati catatan produksi tahun 1998 yang mencapai 43.700 ton. Tahun 2001, dari sekitar 35.000 hektar lahan tanaman kelapa hanya 60 persen dengan produksi 33.000 ton. Selebihnya, 30 persen tanaman muda yang belum menghasilkan dan 10 persen tanaman tua yang tidak produktif. Untuk mengantisipasi menurunnya produksi kelapa, pemerintah kabupaten menyiapkan lahan peremajaan 5.000 hektar. Lewat peremajaan ini diperkirakan Gorontalo mampu menghasilkan Rp 5,4 milyar per tahun dari tanaman kelapa setelah enam tahun.

Pemerintah berencana memberikan nilai tambah komoditas kelapa dengan mengembangkan industri pengolahan berbahan baku kelapa. Sebagai komoditas unggulan, kelapa belum dapat bermain di tataran pasar regional apalagi ekspor. Hanya batang kelapa dan kopra saja yang mampu dipasarkan, itu pun baru sampai Surabaya. Padahal, menurut catatan potensi dan peluang investasi Kabupaten Gorontalo, tidak kurang dari enam industri dengan bahan baku tanaman kelapa masih dapat dikembangkan. Seperti industri minyak kelapa, industri arang tempurung kelapa, sabut kelapa, tepung kelapa, dan karbon aktif. 
Selain kelapa, lapangan usaha pertanian didukung tanaman pangan seperti padi dan jagung. Produksi padi mampu menutupi seluruh kebutuhan konsumsi penduduk Gorontalo. Tahun 2001, Kabupaten Gorontalo menyumbang 66 persen produksi padi Provinsi Gorontalo. Setiap tahun terjadi surplus beras. Begitu pula konsumsi masyarakat meningkat.

Selain padi, palawija juga menjadi catatan. Jagung menjadi andalan kabupaten yang selalu meramaikan perdagangan antarpulau bahkan ekspor. Kegiatan petani jagung sempat lesu pada tahun 2000 karena harga turun. Kegairahan bertanam jagung mulai muncul kembali setelah ada jaminan harga kendali jagung yang ditetapkan pemerintah provinsi, kalau perlu pemerintah provinsi akan membeli jagung petani apabila terjadi surplus di pasar.

Pengembangan jagung menjadi sangat menarik, mengingat keterkaitan antara pertanian, industri, dan peternakan yang sifatnya saling mendukung. Produksi jagung akan terserap oleh industri pakan ternak yang saat ini masih memiliki peluang investasi sangat besar. Keberadaan industri pakan ternak dengan bahan baku jagung akan sangat menguntungkan bagi pengembangan peternakan terutama dengan program penggemukan ternak unggas seperti ayam. Permintaan pasar dari kalangan petani ternak cukup tinggi. Belakangan kebutuhan pakan ternak masih disuplai dari luar daerah.

Sebenarnya tidak beralasan petani mengkhawatirkan kelebihan produksi yang menyebabkan jatuhnya harga jagung. Kebutuhan jagung luar negeri cukup tinggi. Sampai saat ini Malaysia tidak membatasi volume impor jagung dari Indonesia. Begitu pula Jepang menjadi pasar potensial bagi jagung lokal.

Pertumbuhan ekonomi Gorontalo yang diukur berdasarkan kenaikan Produk domestik Regional Bruto (PRDB) pada triwulan II tahun 2007 mencapai 4,75 persen dibandingkan dengan triwulan I Atau pertumbuhan naik sekitar 8,34 persen, dan secara komulatif dari 2007 dibanding tahun 2006 kenaikan sebesar 7,22 persen.

Besaran PDRB atas dasar harga berjalan pada triwulan mencapai 1.194,5 milyar sedangkan yang kontstan pada triwulan yang sama yaitu, Rp 588,2 miliyar, dan tiga sektor yang mengalami pertumbuhan tertinggi adalah sektor pertanian 8,64 persen, sektor pengangkutan dan komunikasi 6,11 persen dan sektor perdagangan, hotel dan restoran 3,81 persen. Pertumbuhan tertinggi adalah pertanian yaitu mencapai 12,22 persen, pertambangan dan pengalian 9,00 persen, perdagangan hotel dan restoran 8,78 persen,"

\subsubsection{Muaro Jambi}

Hal yang sama di daerah Muaro Jambi, sektor pertanian sebagai salah satu penyangga perekonomian daerah Kabupaten Muaro Jambi memiliki peranan yang sangat penting. Posisi kabupaten yang strategis sangat mendukung berkembangnya sektor tersebut. Kabupaten Muaro jambi merupakan daerah yang potensial sebagai daerah pengembangan di sektor pertanian khususnya subsektor perkebunan karet dan kelapa 
sawit, disamping tanaman pangan, hortikultura, perikanan, peternakan dan tanaman perkebunan lainnya

Dalam pembentukan struktur perekonomian di Kabupaten Muaro Jambi sektor pertanian menempati urutan yang pertama sebagai penyumbang kontribusi terbesar yaitu 37.95 persen terhadap total PDRB Kabupaten Muaro Jambi tahun 2005. Urutan kedua ditempati sektor pertambangan dan penggalian sebesar 22.27 persen dan dikuti oleh sektor industri pengolahan sebesar 18.24 persen .

Struktur ekonomi Kabupaten Muaro Jambi pada tahun 2005 secara umum tidak berbeda dengan struktur ekonomi pada tahun sebelumnya. Tiga besar didominasi antara lain pertama sektor Pertanian, kedua Sektor Pertambangan dan Penggalian ketiga Sektor Industri pengolahan.

Sektor Pertanian memberikan kontribusi tertinggi, yaitu sebesar 37.95 persen. Sub Sektor Tanaman Perkebunan masih menjadi primadona dengan memberikan kontribusi dominan pada sektor primer ini sebesar 18.54 persen. Sementara kontribusi terendah diberikan oleh Sub Sektor Perikanan sebesar 2.04 persen.

Grafik 1. Struktur Perekonomian Kabupaten Muaro Jambi Tahun 2005

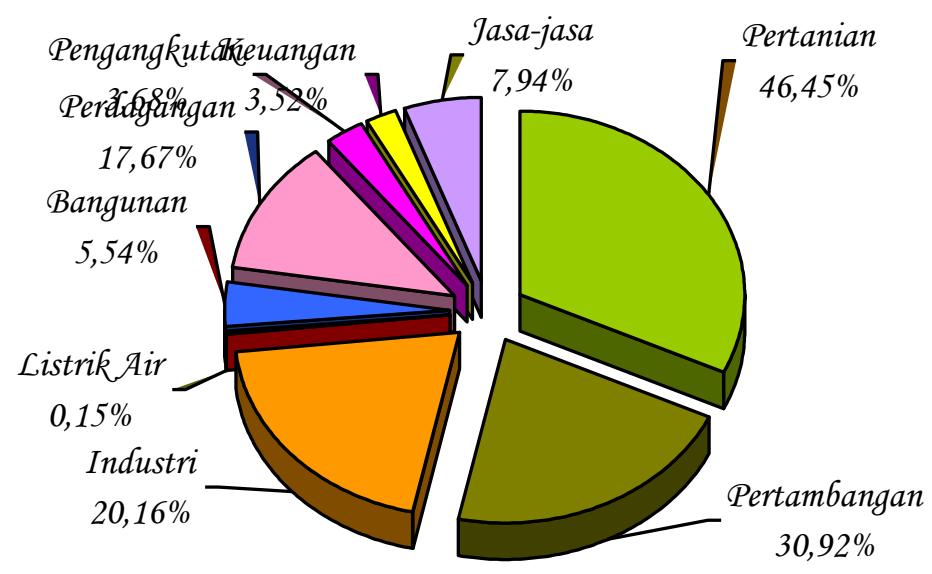


Dalam pembentukan PDRB Kabupaten Muaro Jambi Sektor Pertanian memberikan kontribusi terbesar yaitu 37.95 persen disbanding dengan tahun-tahun sebelumnya, kontribusi sektor ini terhadap pembentukan PDRB secara umum semakin meningkat. Kontribusi sektor pertanian ini tidak lepas dari kontribusi subsektor-subsektor yang membentuk sektor pertanian itu sendiri, dalam hal ini subsektor tanaman perkebunan dan subsektor tanaman bahan makanan masing-masing memberi kontribusi sebesar 18.54 persen dan 6.61 persen terhadap pembentukan PDRB Kabupaten Muaro Jambi.

Meskipun sector pertanian sebagai sector yang paling besar menyumbang kontribusi dalam pembentukan PDRB, namun dalam pembentukan $s$ subsektor yang menjadi penyumbang terbesar berasal dari luar sector pertanian yaitu subsektor minyak dan Gas bumi sebesar 21.44 persen dan subsektor perdangangan Besar dan eceran sebesar 13.53 persen. Dari tahun ke tahun sector listrik dan air bersih merupakan sector dengan andil terkecil dalam pembentukan perekonomian Kabupaten Muaro Jambi. Kontribusi sector ini tidak lebih dari satu persen . meskipun demikian, peranan sector ini tidak dapat diabaikan karena sector ini merupakan sector penunjang untuk semua sector-sektor yang tercakup dalam perekonomian Kabupaten Muaro Jambi.

Adapun banyaknya tenaga kerja yang bekerja pada sektor primer yang terdiri atas sektor Pertanian dan saktor Pertambangan dan Penggalian sekitar 67,58 persen, bekerja di sektor sekunder yang meliputi sektor industri Pengolahan, Listrik/Air dan sektor Bangunan/Konstruksi sebesar 12,06 persen dan sisanya di sektor tersier sejumlah 20,34 persen

Export komoditas perkebunan dikenakan ketentuan tidak melebihi 80 persen, sisanya 20 persen untuk kebutuhan dalam negeri.

Terkait pengembangan wilayah, untuk perusahaan besar sudah ada akses jalan produksi.

\subsubsection{Kutai Kartanegara}

Berbeda dengan Kutai Kartanegara dimana pertanian kurang memberikan peran penting terhadap ekonomi daerah. Struktur ekonomi menunjukkan besarnya peranan nilai tambah masing-masing sector ekonomi dalam menciptakan PDRB. Dengan kata lain bahwa struktur ekonomi menggambarkan ketergantungan daerah terhadap kemampuan produksi masing-masing sector ekonomi. Struktur ekonomi di Kabupaten Kutai Kartanegara sampai saat ini masih didominasi oleh sector primer yaitu sector berbasis pada sumber daya alam seperti sector minyak dan gas bumi. Sektor ini merupakan penyumbang terbesar dalam perekonomian Kutai Kartanegara yaitu sekitar 86,54 persen, sisanya sebesar 13,46 persen diisi oleh sector pertanian, peternakan, kehutanan dan perikanan sebagai penyumbang terbesar kedua. Pada tahun 2000 sektor pertanian, peternakan, kehutanan dan perikanan mampu berperan sebesar 40,56 persen terhadap total PDRB tanpa migas, namun pada tahun 2006 ini hanya mampu berperan sebesar 25,15 persen. 
Komoditi utama perkebunan :

\section{Karet}

Tanaman karet di Kalimantan Timur merupakan komoditi tradisional yang sudah relatif lama diusahakan sebagai perkebunan rakyat, namun karena pengaruh harga yang berfluktuasi sangat tajam usaha perkaretan beberapa waktu yang lalu sempat ditinggalkan oleh petani perkebunan untuk beralih kepada usaha lain yang dianggap lebih menguntungkan. Namun saat ini seiring dengan semakin membaiknya harga karet di pasaran komoditi karet kembali banyak diusahakan oleh masyarakat dan di beberapa tempat komoditi tersebut merupakan sumber mata pencaharian utama masyarakatnya.

\section{Kelapa}

Tanaman kelapa dalam merupakan komoditi tradisional Kalimantan Timur, tumbuh dengan baik pada semua tempat yang diusahakan oleh masyarakat sebagai tanaman perkarangan maupun yang diusahakan dalam hamparan yang cukup luas. Usaha perkebunan kelapa rakyat dalam hamparan yang luas terdapat di Kabupaten Kutai Timur (Kecamatan Sangkulirang, Sandaran dan Kaliorang), Kabupaten Kutai Barat (Kecamatan Melak dan Barong Tongkok), Kabupaten Kutai Kartanegara (Kecamatan Samboja, Muara Jawa dan Kota Bangun), Kabupaten Pasir (Kecamatan Tanah Grogot, Pasir Belengkong dan Long Kali), Kabupaten Penajam Paser Utara (Kecamatan Penajam, Waru, Babulu dan Sepaku), Kabupaten Berau (Kecamatan Talisayan), Kabupaten Nunukan (Kecamatan Nunukan dan Sebatik), Kota Samarinda (Kecamatan Samarinda Utara dan Palaran), Kota Balikpapan (Kecamatan Balikpapan Timur dan Utara.

\section{KelapaSawit}

Era pengembangan kelapa sawit di Kalimantan Timur dimulai pada tahun 1982 yang dirintis melalui Proyek Perkebunan Inti Rakyat (PIR) yang dikelola oleh PTP VI. Sampai saat ini (Posisi Desember 2006) luas areal kelapa sawit baru mencapai 210.553,50 Ha yang terdiri dari 51.389,50 Ha sebagai tanaman plasma / rakyat, 13.551 Ha milik BUMN sebagai inti dan 145.613 Ha milik Perkebunan Besar Swasta. Produksi TBS (Tandan Buah Segar) sebesar 1.273.167,50 ton. Dari sejumlah perusahaan perkebunan besar swasta yang telah memperoleh izin pencadangan (ijin lokasi) sementara ini yang telah beroperasi membangun kebun dalam skala yang luas baru sebanyak 42 perusahaan.

\section{Kopi}

Seperti kelapa dalam, komoditi kopi juga merupakan komoditi yang telah lama diusahakan oleh masyarakat pedesaan di seluruh Kalimantan Timur. Areal tanaman kopi tersebut terdapat hampir merata di beberapa wilayah pedesaan Kabupaten di Kalimantan Timur dan diusahakan oleh petani dengan luasan yang rata - rata relatif terbatas.

\section{Kakao}

Kalimantan Timur merupakan salah satu penghasil kakao rakyat di Indonesia, meskipun arealnya relatif kecil dibading dengan Sulawesi Selatan dan Sulawesi Tengah, tetapi bagi petani dibeberapa tempat di Kalimantan Timur, komoditi tersebut dijadikan sebagai mata pencaharian yang utama. 


\section{Lada}

Lada di Kalimantan Timur merupakan komoditi tradisional yang sudah cukup lama dikenal dan dikembangkan oelh rakyat. Beberapa waktu yang lalu komoditi lada merupakan salah satu komoditi ekspor Kalimantan Timur yang cukup penting, yang dikenal dengan mutu white pepper Samarinda. Setelah harga komoditi tersebut jatuh di pasaran dunia sampai pada titik yang paling rendah dan bencana kebakaran lahan serta kemarau panjang yang melanda Kalimantan Timur tahun 1982 yang lalu produksi lada Kalimantan Timur menurun secara drastis, sehingga sejak saat itu Kalimantan Timur tidak lagi tercatat sebagai pengekspor lada.

\subsubsection{Kampar}

Di Kabupaten Kampar, komoditi perkebunan yang dikembangkan meliputi kelapa sawit, karet dan kakao, dengan pertimbangan komoditi tersebut mempunyai peranan yang sangat strategis sebagai sumber pendapatan, mempunyai prospek pasar, mampu menyerap tenaga kerja dan mempunyai peranan dalam pelestarian fungsi lingkungan hidup. Berkaitan dengan hal tersebut di atas, kontribusi kelapa sawit dan karet sumatera mencapai $83,78 \%$ dari total produksi sebesar 11,8 juta ton dengan share mencapai $72,21 \%$ dari total produksi sebesar 2.065 .817 ton.

Usaha Perkebunan di Riau terdiri dari ;

1. PerkebunanRakyat

Perkembangan usaha perkebunan rakyat mencapai areal 2.026.415 Ha atau $70,64 \%$ terhadap total luas areal perkebunan di Riau Pembangunan perkebunan rakyat tersebut dilaksanakan melalui 2 pola pengembangan

a. Unit PelayananPengembangan(UPP)Berdasarkan sasaran dan peranan, kegiatan pengembangan pola UPP Propinsi Riau terdiri dari 2 bentuk yaitu

- Pola UPP yang kegiatannya perluasan perkebunan rakyat, yang dilaksanakan oleh proyek P2RT, TCSDP dan ISDP, proyek-proyek ini saat ini di Merger menjadi Proyek pengembangan Kawasan Industri Masyarakat Perkebunan (KIMBUN) Riau. Komoditas yang dikembangakan karet, kelapa hibrida dan kopi dengan luas areal 70.486 Ha.

- $\quad$ Pola UPP yang mempunyai kegiatan khusus peningkatan mutu hasil bahan olah karet rakyat yang dilaksanakan oleh Proyek Pengembangan Unit Pengolahan Karet Rakyat (PPUPKR/STCPP) Riau. Pengembangan Unit Pengolahan Karet Rakyat dilaksanakan di Kabupaten Kampar dan Bengkalis (sekarang termasuk wilayah kabupaten Rokan Hilir) sebanyak 450 unit UPH atau setara dengan 22.500 Ha kebun rakyat.
b..Pola
Perusahaan
Inti
Rakyat
PIR
) 
Pengembangan perkebunan Pola PIR dilaksanakan oleh perusahaan inti yaitu perusahaan Perkebunan Besar Negara (PTPN) dan Perkebunan Besar Swasta (PBS) pada pola ini perusahaan inti wajibmembantu dan membimbing petani plsama baik dalam pembangunan kebun maupun peningkatan keterampilan petani

\section{Perkebunan Besar}

Perkebunan besar merupakan bentuk usaha perkebunan yang dikelola oleh Perusahaan baik BUMN (PTPN.V) maupun Swasta. Komoditi perkebunan yang diusahakan adalah kelapa sawit, karet, kelapa hibrida, dan kakao. sesuai dengan rencana Tata Ruang Wilayah (RTRW) Propinsi Riau yang telah di paduserasikan dengan tataguna hutan kesepakatan yang disesuaikan dengan potensi wilayah maka ditetapkan arahan pembangunan perkebunan adalah seluas 3.133.198 ha. Sampai dengan tahun 2004 kawasan pengembangan perkebunan yang telah di keluarkan pencadangannya oleh pemerintah daerah untuk perusahaan adalah sebanyak 284 perusahaan seluas $1.669 .415,81 \mathrm{Ha}$. Pada saat ini perusahaan perkebunan yang aktif yang sebanyak 143 perusahaan. Dari perusahaan yang aktif yang telah mendapatkan Hak Guna Usaha (HGU) sebanyak 101 persuahaan dengan jumlah HGU sebanyak 149 dengan luas areal $\quad 827.293,81 \quad \mathrm{Ha}$.

Perusahaan perkebunan yang telah mendapatkan pencadangan lahan maupun perizinan lainnya tidak melakukan aktivitas dilapangan sampai dengan tahun 2004 tercatat sebanyak 141 perusahaan yang tersebar pada 12 kabupaten/kota. Pada umumnya areal yang di peruntukan perusahaan tersebut terlantar dan sebagian telah diokupasi masyarakat untuk pemukiman dan kebun. Kendala lain yang dihadapi adalah kondisi lahan bergambut tebal dan selalu digenangi air serta banjir pada musim penghujan sehingga tidak memungkinkan untuk ditanami.

Kontribusi sektor pertanian pada triwulan I - 2007 terhadap pertumbuhan Produk Domestik Bruto Regional (PDRB) Riau yaitu mencapai 38,64 persen. Dari kontribusi tersebut $20,08 \%$ diantaranya disumbangkan oleh sektor perkebunan.

Besarnya kontribusi sektor pertanian terhadap PDRB Riau tidak lepas dari besarnya kredit yang disalurkan perbankan di Riau kepada sektor ini. Kredit yang disalurkan perbankan di Riau mencapai Rp14 triliun. Dari jumlah tersebut 24,76\% atau Rp3,47 triliun disalurkan ke sektor pertanian. Dari jumlah tersebut 90,16\% atau Rp3,13 triliun disalurkan ke sektor perkebunan.

\subsubsection{Deli Serdang}

Kabupaten ini memiliki 15.243 hektar perkebunan kelapa sawit rakyat tahun 2000. Lokasinya tersebar di tiga kecamatan, STM Hulu, Kutalim-baru, dan STM Hilir. Perkebunan yang sedikitnya menyerap 797 tenaga kerja menghasilkan tak kurang 159.000 ton. Sementara itu luas lahan karet 26.870 hektar juga tersebar di tiga kecamatan, Sipispis, Masihul dan Bangun Purba. Dari sekitar 8.500 orang yang bekerja di perkebunan rakyat ini, dihasilkan sekitar 145.000 ton karet. 
Bagi kas daerah, realisasi perolehan pajak hasil tanaman perkebunan negara dan perkebunan rakyat tahun 2001 memberikan tidak kurang Rp 23,9 juta. Sedangkan retribusi penebangan atau pemanfaatan kayu karet menghasilkan sekitar Rp 33,8 juta.

Selain dari perkebunan, hasil pertanian kabupaten ini memberikan kontribusi yang tidak sedikit bagi Provinsi Sumatera Utara. Produk kelompok tanaman bahan makanan, misalnya padi, dengan luas panen sekitar 158.000 hektar, pada tahun yang sama menghasilkan sedikitnya 730.000 ton. Jumlah ini kurang lebih 21 per-sen dari total produksi padi provinsi 3,5 juta ton. Tingginya produksi padi yang dihasilkan menjadikan Deli Serdang daerah utama penghasil padi.

Kegiatan ekonomi kabupaten ini turut memberi andil terhadap nilai Produk Domestik Regional Bruto (PDRB) Su-matera Utara. Pada tahun 2000, kabupaten ini membukukan sekitar Rp 7,2 trilyun. Nilai yang diperoleh membuat Deli Serdang menjadi penyumbang terbesar ketiga terhadap total PDRB provinsi setelah Kota Medan dan Kabupaten Asahan. Bagi Deli Serdang, pertumbuhan komoditas unggulan dari kegiatan di bidang pertanian, membuat lapangan usaha ini menjadi kontributor utama. Kegiatan di bidang pertanian memberikan 36,6 persen atau setara $\mathrm{Rp} 2,6$ trilyun, berselisih dua persen dari bidang industry yang sebelumnya selalu menjadi motor penggerak perekonomian kabupaten.

\subsubsection{Buleleng}

Propinsi Bali yang luasnya sekitar $5633 \mathrm{~km}^{2}$, dengan kepadatan sekitar 582 jiwa/km², dimana sekitar $21 \%$ penduduk bekerja di lapangan usaha pertanian. Penguasaan pemilikan tanah pertanian relatif sempit. Sebagai contoh di Kabupaten Buleleng luas pemilikan tanah sawah/kapita sekitar 0,212 hektar dan tanah kering (tegalan dan kebun campuran) sekitar 0,067ha per kapita. Potensi pertanian tanaman pangan di daerah Bali dengan komoditas andalan seperti padi, jagung, ubi kayu, ubi jalar, dan buah-buahan hampir tersebar di seluruh wilayah pulau Dewata ini.

Di Kabupaten Buleleng, sekitar $46 \%$ penduduk masih bekerja di sektor pertanian, dengan pendapatan per kapita sekitar Rp 3,57 juta. PDRB kabupaten sekitar Rp 3,2 trilyun, dimana sektor pertanian kontribusinya sekitar $32 \%$ PDRB Komoditi pertanian yang utama di wilayah itu adalah kopi, cengkeh dan vanili.

\subsection{Permasalahan HGU terkait Program Kemiskinan}

Kemiskinan selalu dikaitkan dengan faktor ekonomis, yang dinyatakan dalam ukuran tingkat pendapatan (income) atau tingkat konsumsi individu atau komunitas. Lembaga donor internasional seperti Bank Dunia atau Bank Pembangunan Asia (ADB), sebagai contoh, pada periode sebelumnya menggunakan tingkat pendapatan $\$ 1$ per hari sebagai batas proverty line. Sementara di negara-negara berkembang kemiskinan diukur dengan tingkat pemenuhan kebutuhan dasar, yang dinyatakan dalam ukuran kebutuhan hidup minimum atau kebutuhan kalori. 
Pandangan di atas jelas berimplikasi pada pendekatan yang digunakan untuk mengentaskan kemiskinan tersebut. Seperti banyak diterapkan di negara-negara berkembang umumnya upaya pengentasan kemiskinan dilakukan dengan pembangunan yang bertumpu pada pertumbuhan ekonomi. Para pengambil keputusan memandang pertumbuhan output nasional dan regional yang dinyatakan dalam pendapatan perkapita atau GNP dapat mendorong kegiatan ekonomi lainnya (multiplier effect), yang pada gilirannya menciptakan lebih banyak lapangan kerja dan peluang berusaha.

Namun pengalaman menunjukkan peningkatan produk domestik bruto (GNP) tidak dengan sendirinya membawa peningkatan standar hidup masyarakat secara keseluruhan maupun individu. Ada dua alasan mengapa hal tersebut tidak berlaku. Pertama, umumnya pertumbuhan penduduk di negara-negara berkembang lebih besar daripada pertumbuhan ekonomi sehingga secara komparatif tidak memberikan peningkatan taraf hidup secara signifikan.

Selanjutnya, adanya ketidakadilan dan struktur ekonomi yang tidak berpihak kepada kaum miskin, membuat output pertumbuhan tersebut tidak terdistribusi secara. merata. Teori trickle down effect yang mendasari kebijakan di atas tidak berlaku sepenuhnya. Kemakmuran tersebut umumnya hanya akan "menetes" kepada lapisan masyarakat tertentu yang secara komparatif memiliki pengetahuan, ketrampilan, daya saing, dan absorptive eapacity yang lebih baik. Sementara mereka yang benar-benar miskin dan mengalami apa yang disebut kemiskinan absolut jarang mengenyam hasil pembangunan tersebut. Bahkan,sering pembangunan justru membuat mereka mengalami marginalisasi, baik fisik maupun sosial.

Untuk mendorong perekonomian rakyat, banyak para ahli yang menyarankan agar paket-paket deregulasi dapat secara langsung membantu atau mendorong tumbuhnya perekonomian rakyat, sekaligus untuk mengatasi kesenjangan antara golongan ekonomi kuat dengan golongan ekonomi lemah. Untuk itu, selain perlunya peranan pemerintah, maka pengembangan keswadayaan masyarakat juga penting artinya. Pengembangan keswadayaan masyarakat selain memerlukan kebijakan publik yang menyentuh kepentingan masyarakat, inisiatif dari bawah, yang berasal dari masyarakat, juga diperlukan.

Program perkreditan, seperti Kredit Investasi Kecil (KIK), Kredit Usaha Kecil (KUK), Kredit Modal Kerja Permanen (KMKP), Kredit Umum Pedesaan (Kupedes), dan program perkreditan lainnya yang melekat dengan program BIMAS dan INMAS merupakan bagian dari usaha menggerakkan ekonomi rakyat. Namun hal tersebut masih perlu dikembangkan dan masih memerlukan kajian, terutama yang menyangkut efektifivitasnya. Kebijakan perkreditan untuk golongan ekonomi lemah ini sering mendapat kritikan, terutama faktor bunga yang terlalu tinggi atau bunga terlalu rendah, sehingga tidak mendorong petani untuk menggunakan fasilitas kredit tersebut untuk meningkatkan usaha produktif.

Saat ini pemerintah mengajukan program pembangunan dengan jalur pendekatan yang pro-growth, pro-poor, dan pro-job untuk mendorong percepatan revitalisasi pertanian, 
yaitu dengan mengimplementaskan program kredit revitalisasi perkebunan yang penyalurannya akan dikoordinir oleh Bank BRI.

Hal ini dikarenakan perkebunan masih memegang peranan penting bagi perekonomian nasional, khususnya sebagai penyedia lapangan kerja, sumber pendapatan dan devisa negara. Menyadari akan pentingnya peran perkebunan dan memperhatikan kondisi umum perkebunan Indonesia, maka pemerintah telah mencanangkan program revitalisasi perkebunan khususnya untuk komoditas karet, kelapa sawit dan kakao. Kegiatan revitalisasi tersebut meliputi rehabilitasi, peremajaan dan perluasan perkebunan. Pemerintah telah meminta kesediaan Lembaga Keuangan (Bank Mandiri, Bank BRI, Bank BNI), untuk menyediakan dana kredit yang bunganya akan disubsidi oleh pemerintah. Dana yang akan disalurkan sebesar Rp 10 triliun dengan tingkat bunga $10 \% /$ tahun.

Revitalisasi perkebunan ini khusus untuk pembiayaan kepada petani plasma perkebunan kelapa sawit, karet, dan kakao, dan bukan kepada perusahaan inti. Namun terdapat hal yang perlu dicermati, yaitu revitalisasi perkebunan lingkup pemerataannya sangat terbatas, yaitu hanya untuk petani perkebunan kelapa sawit, karet dan kakao dengan areal demografis yang terbatas pula.

Diharapkan, lima tahun ke depan, sasaran revitalis pertanian adalah terciptanya dua juta hektar perkebunan. Terdiri atas 1,5 juta hektar kelapa sawit, 300 ribu hektar karet dan perkebunan kakao 200 hektar dan pembukaan lahan baru tersebut diharapkan akan menyerap satu juta tenaga kerja.

Di Kabupaten Gorontalo, serapan tenaga kerja secara umum untuk HGU yang luasnya $100-200$ ha tenaga kerja \pm 10.000 orang/ha yang menggunakan tenaga kerja setempat dan tenaga dari Jawa dan Makassar. Untuk Pabrik Gula Tenaga Kerja sebagai buruh pengumpul, upah buruh untuk penanaman tebu memakai sitem borongan per areal hasil kerja, tebangan Rp. 40.000/hr/orang, pemeliharaan Rp. 25.000/hari/orang.

Hasil panen 1 ha memperoleh \pm Rp. 9.000 .000 (bersih), kotor RP. 11.000.000, jangka waktunya 8-12 bulan, setelah dipotong masih bisa diproduksi sampai $5 \mathrm{x}$, pendapatan petani Rp. 900.000/bulan/ha.

Rata-rata pemilikan masyarakat 2-3 ha, paling sedikit 1 ha, paling banyak 5 ha, ratarata 0,5-2 ha. Usaha perkebunan bagi masyarakat setempat bersifat sekunder bukan primer karena mereka masih mengandalkan sawah.

Di Kabupaten Muaro Jambi, serapan tenaga lokal/penduduk sekitar yang digunakan oleh perusahaan perusahaan cukup banyak, dan sistem penggajiannya menggunakan standar UMR setempat yaitu lebih kurang Rp. 22.000/hari, dan Rp 400.000 - Rp $600.000 /$ bulan.

Di Kabupaten Kutai Kartanegara, serapan tenaga lokal/penduduk sekitar yang digunakan oleh perusahaan $\pm 75 \%$, sisanya dari luar daerah, sistem penggajiannya juga menggunakan standar UMR regional. 
Demikiian halnya di Provinsi Sumatera Utara serapan tenaga lokal cukup besar juga diambil buruh dari Jawa, standar gaji menggunakan UMR regional dengan tambahan bonus jika dapat mengambil kelapa sawit lebih dari yang ditargetkan.

Hubungan antara pemegang HGU dengan masyarakat sebagian besar terjadi konflik, banyak kasus HGU yang sudah habis jangka waktunya atau sedang dalam proses untuk perpanjangannya diklaim oleh masyarakat sekitar. Terjadi okupasi oleh masyarakat kalau HGU tidak diusahakan, misalkan masih berupa hutan namun sudah keluar HGU. Perlu dikembangkan pola hubungan antara masyarakat dengan perusahaan perkebunan agar tidak terjadi konflik atau permasalahan yang dapat memicu terjadinya okupasi oleh masyarakat. Perusahaan Perkebunan harus memperhatikan kepentingan masyarakat di sekitarnya baik dengan mempekerjakan masyarakat sekitar di lahan perkebunan maupun dengan pola lain.

\section{BAB V}

\section{MODEL PENATAAN HGU}

\subsection{Model yang telah ada}

\subsubsection{Pola Kemitraan yang ada}

Pola inti-plasma yang digunakan selama ini menciptakan integrasi antara perkebunan besar dengan perkebunan rakyat melalui suatu organisasi produksi yang mengaitkan secara vertikal satuan-satuan usaha rakyat dengan perusahaan perkebunan yang bermodal besar. Dalam skema ini petani-petani kecil atau "plasma" dikontrak oleh pihak perusahaan sebagai "inti" untuk menghasilkan komoditas pertanian sesuai yang ditentukan oleh kontrak. Perusahaan yang membeli hasil pertanian itu dapat memberikan bimbingan teknis, saprotan, kredit dan lain-lain, serta menjamin pengolahan dan pemasaran pada kemitraan selama ini mendapat banyak kritik terutama menyangkut pola hubungan antara perusahaan inti dengan petani plasma yang tidak seimbang.

Pola inti-plasma yang bersifat hirarkis juga telah mendapat banyak kritik terutama menyangkut pola hubungan antara perusahaan inti dengan petani plasma yang tidak seimbang. Dengan memberikan kegiatan produksi pada petani, maka pihak perusahaan sesungguhnya telah menghindarkan diri dari resiko dan ketidakpastian yang ada dalam investasi produksi maupun perubahan harga di pasar, dengan cara mengalihkan resiko-resiko tersebut kepada petani peserta. Dan walaupun biasanya soal mutu dan harga telah ditentukan dalam perjanjian, tetapi pengambilan keputusan mengenai mutu (yang bakal menentukan apakah bahan baku milik petani diterima atau tidak) sepenuhnya monopoli pihak inti. Hal semacam ini membuat petani peserta selalu diposisikan sebagai pihak yang dirugikan.

Lebih dari itu, dengan membenamkan petani ke dalam kegiatan produksi, juga tidak memberi ruang sama sekali kepada petani untuk terlibat dalam proses pengolahan produksi dan kegiatan industri turunannya. Sebagai "plasma", maka petani tidak memperoleh kesempatan untuk membangun institusi ekonominya sendiri yang cukup 
kuat dan dapat membuat skala usahataninya meningkat lebih baik, misalnya dengan memampukan mereka untuk terlibat dalam berbagai tahap proses produksi.

Model kemitraan yang ditemukan diberbagai daerah meliputi :

1) Model inti Plasma,

Tanah disewakan oleh perusahaan, setelah jadi kebun, dilakukan penilaian oleh TP3D (tim Penilai Kebun) layak atau tidak, jika dinilai layak maka hasil dari kebun dikembalikan untuk membayar kredit $30 \%$ kepada perusahaan, $70 \%$ untuk petani.

Gambar 1:Model inti plasma

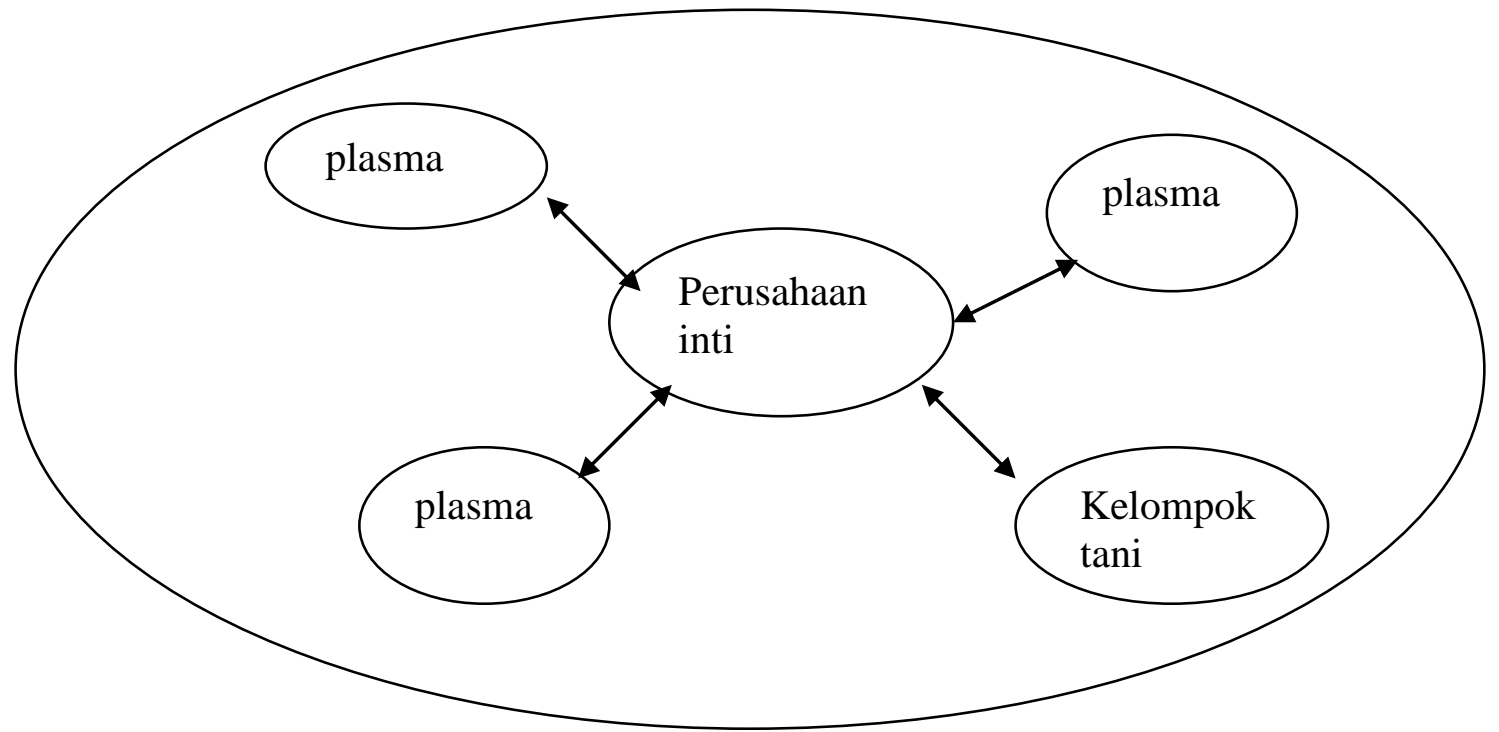

2) Model KKPA

Dibentuk koperasi yang mewakili kelompok tani, di dalam kelompok tani ada masyarakat, masyarakat mempunyai lahan garapan diserahkan pada perusahaan untuk membangun kebun sampai produksi, dengan perjanjian perusahaan mendapat $30 \%$, masyarakat mendapat 70 , dengan dibebani kredit dari membangun kebun untuk perusahaan melalui bapak angkat (Bank Mandiri, BRI atau BNI).

Kalau sudah layak dikonversi menjadi Hak Milik dan diredistribusikan, sertipikat Hak Milik yang dijaminkan, contoh konkritnya, jika masyarakat mempunyai garapan 3 ha, dibangunkan kebun oleh inti, 1 ha diserahkan ke perusahaan inti, 2 ha untuk masyarakat, biaya membangun kebun perhektar 18 juta, berarti kredit masyarakat 2 ha $\mathrm{x} 18$ juta = 36 juta, yang diagunkan 2 ha ke bank, itulah yang menjadi hak milik, 1 ha menjadi HGU (perusahaan). 
Gambar 2 Model KKPA

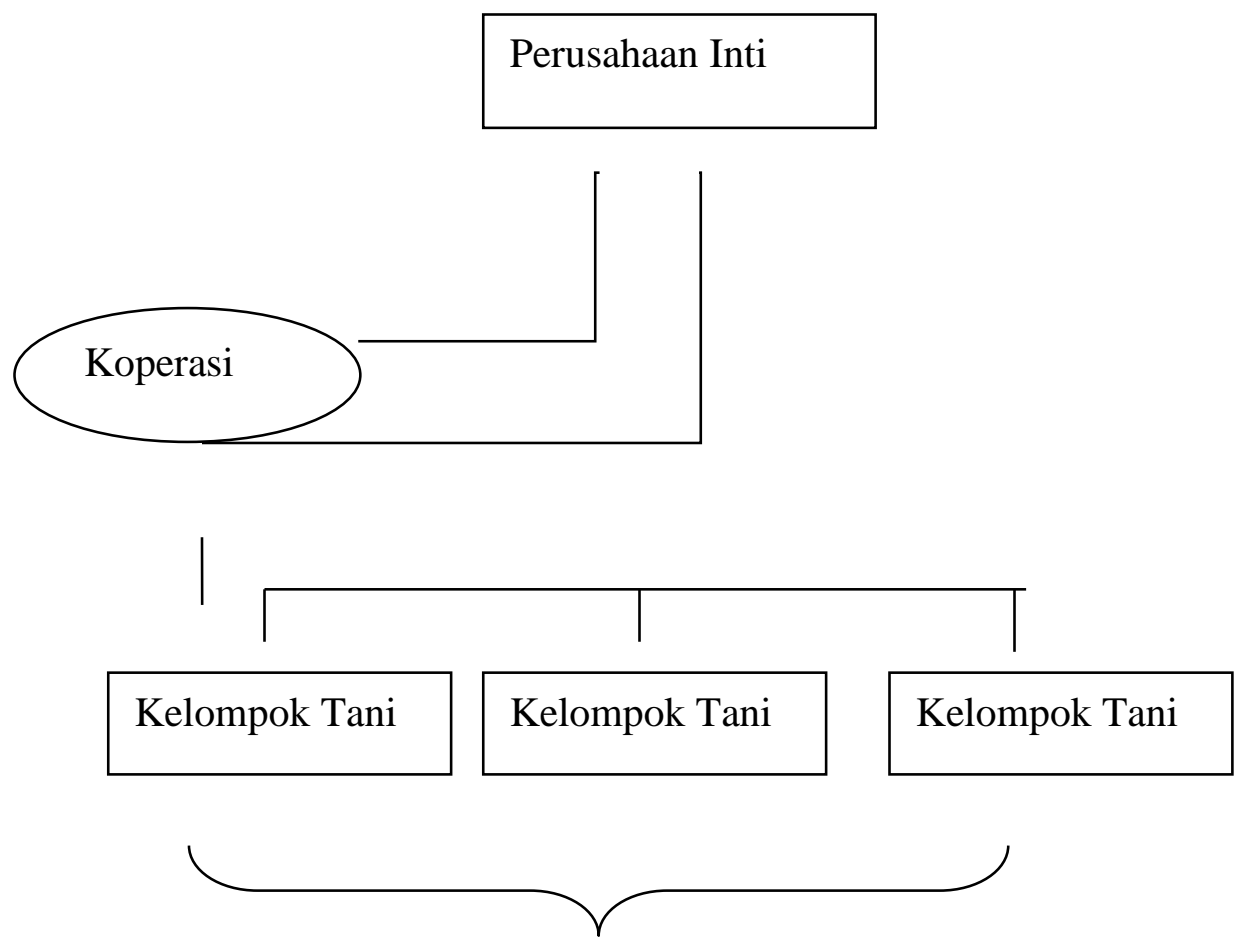

Plasma

Model seperti ini banyak dijumpai di Provinsi Jambi dan juga dikembangkan di Kecamatan Paya Rumbai, Kabupaten Inderagiri Hulu, Provinsi Riau dengan areal seluas $10000 \mathrm{Ha}$ dalam bentuk redistribusi kebun sawit, dikenal dengan Proyek Kredit Pemilikan Kebun (KPK). Terdapat tiga hal pokok yang diatur dalam pola redistribusi kebun dengan pola kemitraan, yaitu

(a) proses seleksi peserta,

(b) pembagian kebun produktif dan telah bersertipikat hak milik serta

(c) pendanaan melalui KPK.

Pihak swasta membangun areal kebun dan setelah memasuki usia produktif, sekitar 30 persen arealnya didistribusikan kepada masyarakat setempat dengan luasan 2 hektar per KK. Petani menerima kebun yang sudah produktif dan tanahnya sudah bersertipikat hak milik. Kewajiban petani adalah mengangsur kredit pemilikan sesuai nilai kredit yang disepakati , melalui Bank Persepsi setempat.

Masa angsuran 12 tahun dengan bunga sekitar $14-16 \%$ per tahun. Sumber cicilan adalah penjualan hasil produksi sawit. Konsep itu telah berhasil mengatasi kesenjangan pemilikan tanah, mencegah terjadinya tanah terlantar akibat ketidakmampuan manajemen kebun serta meningkatkan pendapatan masyarakat sekitar kebun. 
Ada 3 pola kemitraan yang dikenal di Provinsi Jambi yaitu :

- Kemitraan murni; tanah disewakan oleh perusahaan, yang menanamkan juga perusahaan

- Kemitraan dalam bentuk KKPA(kredit Koperasi Primer Anggota); sertipikat diberikan atas nama kelompok tani, pemberian sertipikat dilakukan melalui redistribusi.

- Kemitraan koperasi; sistemnya 50:50, dimana ada tanah yang belum terbuka dari luas $1000 \mathrm{~m} 2$ diberikan masyarakat $500 \mathrm{~m} 2$

Pada kemitraan Koperasi yang mewakili kelompok masyarakat adalah KUD yang ada dikenal dengan nama Wahana Jaya, KUD ini membawahi masyarakat, mitra dengan perusahaan PT Sumber Taman Nusa Pertiwi (bapak angkat/plasma), masyarakat dapat 20 persen tapi tidak dibebani kredit melainkan langsung diterima masyarakat, sedangkan 80 persennya diperoleh PT. KUD mendapat fee dari Perusahaan dan HGU atas nama KUD.

3) Kerjasama Operasional (KSO),

merupakan hubungan kemitraan yang di dalamnya kelompok mitra menyediakan lahan, sarana dan tenaga kerja, sedangkan perusahaan mitra menyediakan biaya atau modal dan/atau sarana untuk mengusahakan atau membudidayakan suatu komoditi perkebunan.

Gambar 3 Model Kerjasama Operasional (KSO),

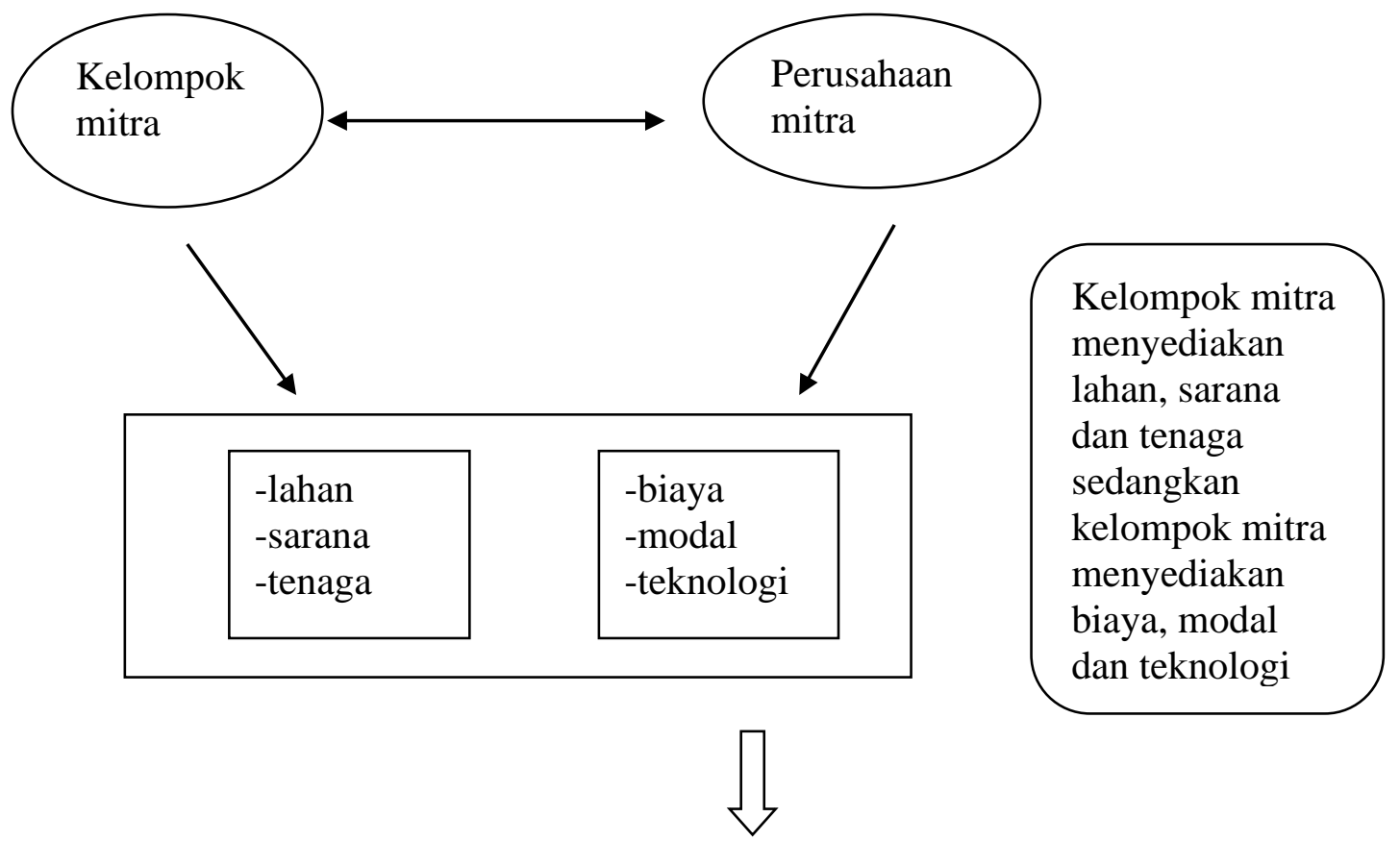

Pembagian hasil sesuai dengan kesepakatan 
Model kemitraan terebut di atas ditemukan di Provinsi Gorontalo yaitu, Pabrik Gula Tolangohula melakukan kerja sama dalam hal bibit, bajak, pupuk, tebangan, angkutan disediakan oleh perusahaan, dihitung kemudian dipotong dari hasil kerjasama dengan (Asosiasi Petani Tebu Rakyat APTRN). Kemitraan dilakukan secara tertulis dengan adanya MOU antara perusahaan dan masyarakat. Ada pula Koperasi Petani Tebu yang mendapat dukungan dari Pemda berupa bantuan biaya operasional penanaman.

4) Model Kemitraan terpadu hulu-hilir

Pengembangan kebun kelapa sawit di Kabupaten Siak yang merupakan hasil kerjasama antara Pemda Siak dan PTPN V. Skema pengembangan kebun sawit ini dibagi dua yaitu jangka pendek dan jangka panjang. Skema jangka pendek merupakan sebuah cash program di mana Pemda melakukan konsolidasi tanah untuk dibangun menjadi kebun kelapa sawit. Tanah yang dikonsolidasi sebagian besar berasal dari masyarakat dan sebagian dari tanah negara.

Pengertian tanah masyarakat adalah termasuk tanah negara yang telah dikuasai oleh masyarakat, meski belum ada jaminan legalnya berupa sertifikat. Petani yang memiliki tanah kurang atau lebih dari 3 hektar, dikenakan ketentuan penetapan calon lahan (CL). Tanah-tanah yang telah dikonsolidasi ini kemudian dibangunkan menjadi kebun kelapa sawit oleh PTPN V selaku kontraktor atas pembiayaan dari APBD.

Setelah lahan dibangun menjadi kebun sawit siap panen, maka baru diserahkan kepada petani di mana setiap rumahtangga petani yang terlibat akan menerima tanah seluas 3 hektar (di sini terletak sisi redistribusi lahannya). Bagi mereka yang sebelumnya memiliki tanah lebih dari 3 hektar, maka kelebihan itu nilainya diperhitungkan sebagai pembayaran kredit yang harus ia angsur. Sementara bagi yang sebelumnya memiliki tanah di bawah 3 hektar, tambahan tanah itu diperhitungkan sebagai beban tambahan kredit yang harus ia angsur.

Dalam skema jangka pendek ini PTPN V hanya bertindak sebagai pembangun kebun, sedangkan pembiayaannya menjadi tanggung jawab Pemda Siak. Sampai saat ini lahan yang telah selesai dibangun menjadi kebun kelapa sawit adalah seluas 3.500 hektar. Tahap kedua sedang dalam proses penanaman dan mencakup lahan seluas 4.182 hektar. Tahap III sedang dalam proses inventarisasi lahan seluas 7.398 hektar, dan tahap IV seluas sekitar 9.850 masih dalam tahap perencanaan. 
Gambar 4 Kemitraan Terpadu Hulu-hilir

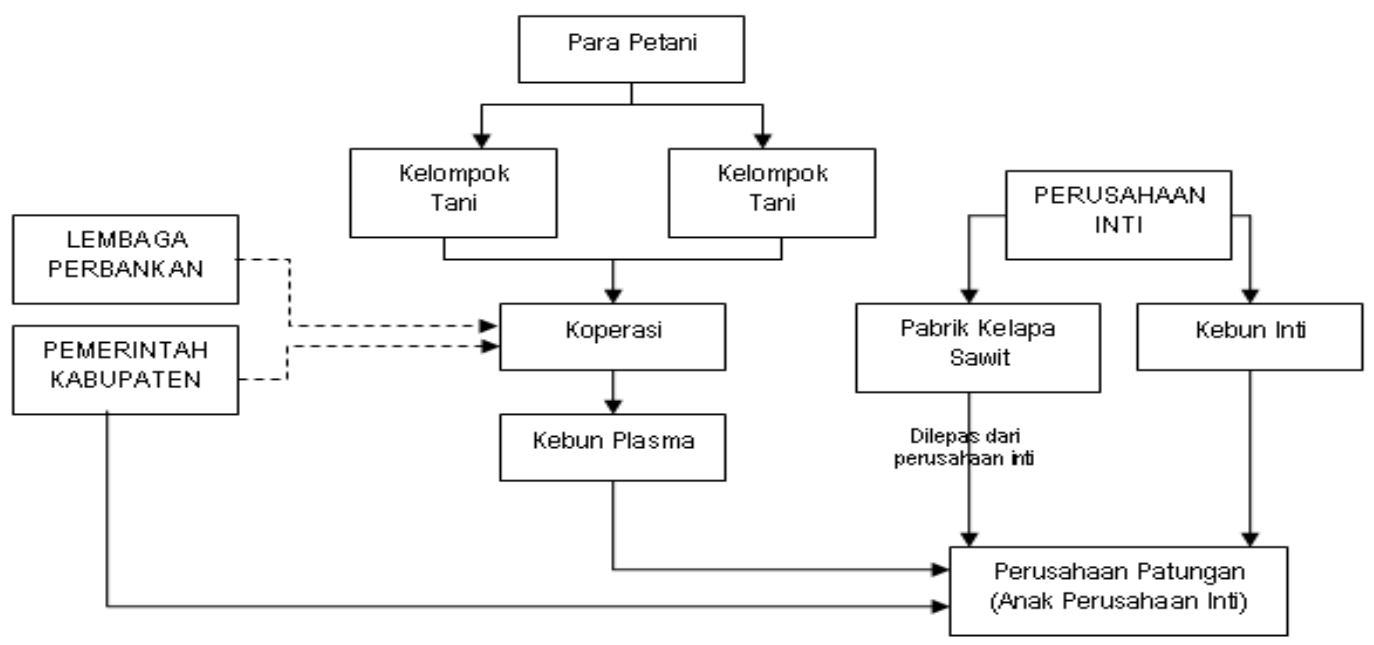

Dalam Peraturan Menteri Pertanian Nomor 26/Permentan/OT.140/2/2007, pola kemitraan yang digunakan ada dua bentuk yaitu :

- Pola Kemitraan pengolahan, kemitraan ini dilakukan berdasarkan pada asas manfaat dan berkelanjutan yang saling menguntungkan, saling menghargai, saling bertanggung jawab dan saling memperkuat.

Dalam hal ini masyarakat berhak memperoleh lahan 20 persen sedangkan perusahaan 80 persen dikenal dengan pembagian 80:20, pembangunan kebun untuk masyarakat dilakukan melalui pola kredit, hibah atau bagi hasil.

- Pola kemitraan usaha, kemitraan ini dilakukan untuk pemberdayaan dan peningkatan nilai tanah bagi pekebun, karyawan dan/atau masyarakat sekitar perkebunan, serta untuk menjamin kelanjutan usaha perkebunan.

Pengalihan kebun kepada petani peserta pada saat tanaman mencapai umur menghasilkan sesuai jenis tanaman dan memenuhi standar teknis yang ditetapkan Direktur Jenderal Perkebunan. Pengalihan kebun tersebut diikuti dengan penyerahan sertipikat tanah sebagai agunan dan penanda tanganan akad kredit dengan perbankan. Pengembalian kredit dilakukan oleh petani peserta setelah kebun dialihkan kepada petani peserta, paling lambat mulai tahun ke-6 (enam) sampai dengan tahun ke 13 (tiga belas) untuk kelapa sawit, dan paling lambat mulai tahun ke-8 (delapan) sampai dengan tahun ke-15 (lima belas) untuk karet (repayment period).

\subsubsection{Luasan dan jangka waktu HGU}

Menurut responden, luasan HGU yang ada sekarang sudah cukup baik, , luas maksimum tanah yang diberikan dengan Hak Guna Usaha kepada perorangan adalah 25 hektar, dan luas minimum adalah 5 hektar. Sedangkan, luas maksimum tanah yang dapat diberikan HGU kepada Badan Hukum ditetapkan oleh Kepala Badan Pertanahan 
Nasional RI mempertimbangkan pejabat yang berwenang di bidang usaha yang bersangkutan, dengan mengingat luas yang diperlukan untuk pelaksanaan suatu satuan usaha yang berdaya guna di bidang yang bersangkutan (Pasal 5 ayat (3) PP 40 Tahun 1996).

Mengenai perpanjangan HGU, UUPA, Pasal 29 ayat (3), menyatakan bahwa atas permintaan pemegang hak dan mengingat keadaan perusahaannya jangka waktu dapat diperpanjang dengan paling lama 25 tahun. Namun tidak dijelaskan mengenai pembaruan hak, baik untuk Hak Guna Usaha maupun hak tanah lainnya seperti Hak Guna Bangunan dan Hak Pakai.

Menurut responden jika akan disempurnakan jangka waktunya sebaiknya 25 tahun dan diperpanjang 20 tahun. Hal ini dikarenakan adanya kekuatiran kemungkinan tanah tidak dimanfaatkan secara optimal. Kenyataan yang terjadi di berbagai areal HGU adalah bahwa hak yang telah diberikan untuk menguasai dan pemanfaatan tanah oleh pengusaha HGU, tidak diikuti dengan pemenuhan kewajiban, sehingga menimbulkan tanah terlantar di areal HGU.

Kondisi tersebut di atas pada hakikatnya mengindikasikan telah terjadi ketidakadilan dalam penguasaan dan pemilikan tanah. Ketidakadilan itu muncul ketika perusahaan pemegang Hak Guna Usaha (HGU) yang menguasai tanah sedemikian luasnya dengan jangka waktu lama, namun tanah itu tidak dimanfaatkan/digarap sesuai dengan keadaan, tujuan dan sifat pemberian haknya, sedangkan di sisi lain sebagian besar masyarakat sekitar areal kebun, tanah usahanya relatif sempit bahkan ada yang tidak mempunyai tanah usaha lagi. Ketidak adilan itu semakin jelas ketika areal yang terlantar itu, telah dijadikan jaminan kredit pada Bank, yang kemudian uang hasil kredit itu, tidak digunakan untuk membangun kebun. Pendapat ini tentunya jauh berkurang lamanya dibandingkan dengan ketentuan yang ada saat ini dan terlebih lagi dengan UU Penanaman Modal yang memungkinkan jangka waktu HGU sampai 90 tahun.

Sedangkan responden Kepala Kantor Perkebunan mengusulkan mengenai jangka waktu sebaiknya ada uji coba 5 tahun pertama baru diberikan selebihnya (20 tahun) jika dikerjakan dengan baik dan mengenai luasan HGU sebaiknya pemberian HGU tidak langsung diberikan dalam skala yang sangat luas, tapi dilakukan secara bertahap, cukup diberikan pertama 5000 ha dulu jika diusahakan dengan baik baru ditambah luasannya. Untuk masyarakat sebenarnya diberikan luasan 2 ha saja sudah cukup memadai. Dalam program revitalisasi perkebunan lahan untuk pengembangan perkebunan untuk masing-masing petani peserta paling luas atau maximum 4 ha. Program BPN untuk membagi-bagikan tanah malah berbahaya, yang untung justru Kepala Desa, lebih baik revitalisasi perkebunan dimana masyarakat dibangunkan kebun dan diberikan bantuan tiap tahun.

Untuk menghindari terjadinya spekulasi tanah, maka perlu diatur bahwa HGU hanya dapat diberikan setelah tanahnya diusahakan minimal seperempat dari tanah yang dimohon, penilaian dilakukan oleh Tim yang terpadu antara BPN dan Pemda (Perkebunan). 


\subsubsection{Hak dan Kewajiban Pemegang HGU}

Adanya kewajiban terhadap pemegang HGU untuk melaksanakan klausul dalam SK Pemberian HGU antara lain seperti :

a) Penerima HGU wajib memelihara keberadaan tanda-tanda batas bidang tanahnya,

b) Penerima HGU dilarang menelantarkan tanahnya

c) Tanah yang diberikan harus dipergunakan untuk usaha sesuai dengan jenis usahanya ,

d) Penerima HGU diwajibkan untuk mengusahakan perkebunan secara produktif sesuai dengan kelayakan usaha berdasarkan kriteria yang ditetapkan oleh instansi teknis

e) Penerima HGU diwajibkan untuk membangun serta memelihara prasarana lingkungan dan fasilitas tanah dalam areal tersebut.

f) Penerima HGU diwajibkan untuk memelihara kesuburan tanah, mencegah kerusakan sumber daya alam dan menjaga kelestarian kemampuan lingkungan hidup sesuai dengan peraturan perundang-undangan

g) Penerima HGU wajib memanfaatkan potensi dan memberdayakan masyarakat di daerah sekitarnya serta menyiapkan sarana fasilitas sosial dan fasilitas umum.

Di Provinsi Jambi, Pengendalian terhadap penguasaan tanah HGU dilaksanakan oleh Pemda dalam hal ini TP3D (Tim Pembinaan Permasalahan Perkebunan Daerah) yang terdiri dari instansi terkait, mekanisme pengendalian ini lebih mengarah kepada optimalisasi pemanfaatan lahan. BPN tidak mempunyai kewenangan untuk menetapkan hasil pengawasan penggunaan lahan HGU karena aturan hukum yang tidak memberikan kewenangan itu dan diharuskannya ada usulan dan rekomendasi dari instansi lain(Pemda).

\subsubsection{Program Pemberdayaan Masyarakat}

Terjadinya konflik antara masyarakat dengan perusahaan perkebunan dapat terjadi karena kurangnya pemahaman masyarakat terhadap hukum pertanahan. Oleh karenanya untuk memberikan pemahaman kepada masyarakat maka perlu dilaksanakan program pemberdayaan. Selama ini BPN sudah mengembangkan kegiatan pemberdayaan masyarakat baik melalui program POKMASDARTIBNAH maupun program lainnya.

Pemberdayaan kelompok masyarakat sadar dan tertib pertanahan (POKMAS) sebagai institusi lokal merupakan langkah penting dalam meningkatkan partisipasi masyarakat dalam pengelolaan pertanahan secara mandiri. Langkah pemberdayaan dilakukan melalui sosialisasi dan penyuluhan tentang hukum pertanahan. Sosialisasi dan penyuluhan tersebut selanjutnya diharapkan dapat meningkatkan pengetahuan dan 
kesadaran masyarakat akan pentingnya swakelola pertanahan. Dalam POKMAS inilah partisipasi masyarakat akan ditingkatkan dengan memberikan pemahaman akan hak dan kewajiban dalam kepemilikan tanah, upaya mandiri dalam menyelesaikan sengketa atau konflik tanah tanpa harus melibatkan lembaga lain seperti peradilan.

Selain pola pemberdayaan di atas, pemberdayaan masyarakat dengan bagi hasil dan pemilikan secara kolektif dan dukungan system inovasi dimana unit-unit kerja terkait dengan pendekatan sistemik akan mendorong proses pembelajaran bagi petani/pekerja bersama-sama dengan pemilik tanah. Penyediaan bibit, pupuk obat-obatan, saprotan dari berbagai unit kerja. Pemerintah Daerah Kabupaten/Kota hendaknya dapat dibangun proses pembelajaran, misalnya cara-cara persemaian untuk bibit dan penyuluhan. Metode seperti ini yang coba dilakukan di Gorontalo.

Kelemahan dari program pemberdayaan yang ada saat ini, hanya bersifat temporer dan melekat pada satu kegiatan yang akan atau sedang dilaksanakan, sehingga tidak berkelanjutan,akibatnya masyarakat yang pernah dimobilisasikan untuk ikut serta dalam progam pemberdayaan masyarakat akan melupakan kegiatan dan pemahaman yang telah mereka dapatkan dari program tersebut.

\subsection{Model yang dapat dikembangkan}

\subsubsection{Pola Kemitraan}

Pola kemitraan yang ada sekarang merupakan kebijakan yang dibuat oleh Departemen Pertanian (Perkebunan), sebaiknya kebijakan ini juga diintegrasikan dengan kebijakan BPN, melalui Program Pembaruan Agraria.. Kebijakan ini juga harus dikuatkan dengan adanya sanksi untuk memelihara tanah dan kebun yang sudah diberikan sehingga tidak akan dimanfaatkan oleh para spekulan.

Apabila tidak dimanfaatkan dapat mengalokasikan tanah HGU tersebut kepada pihak lain yang membutuhkan untuk didayagunakan - termasuk petani tidak bertanah (the best use of land). Kondisi ini diharapkan bisa memberikan akses manfaat dan keterlibatan yang lebih besar kepada petani terhadap usaha perkebunan yang ada di lingkungan mereka. Dan pada akhirnya dapat memberi peluang terjadinya pola kemitraan antara perusahaan perke.bunan dan perkebunan rakyat yang lebih setara dan memberi keuntungan timbal balik.

Peran Koperasi harus ditingkatkan, sehingga petani dapat memiliki peranan yang proporsional karena memiliki saham (melalui koperasi) dalam perusahaan, di samping turut terlibat dalam proses manajemen melalui perwakilan yang ditunjuk. Sementara dari sisi pendapatan, petani selain memperoleh penghasilan dari penjualan produksi (misalkan kelapa atau kelapa sawit) dan dari upah (apabila ia juga bekerja di pabrik kelapa atau kelapa sawit), ia juga memperoleh dividen dari saham koperasi pada perusahaan patungan. Belum lagi aktivitas ekonomi lain yang akan berkembang lebih lanjut sebagai multiplier effect yang ditimbulkannya. 
Dari beberapa model kemitraan yang telah dipaparkan di atas, masing-masing mempunyai kelemahan dan kelebihan, kemungkinan dapat dikembangkan model KKPA dengan pola redistribusi, sehingga ada kemandirian dari petani.

\subsubsection{Luasan dan jangka waktu HGU}

Luasan HGU sebaiknya dibagi dalam dua klasifikasi yaitu :

- Jawa Sumatera

luasan perlu dibatasi hanya diberikan antara 5-25 ha (max 35 ha), dengan ketentuan harus sudah diusahakan baru dapat diajukan HGU. Hal ini untuk menghindari tanah diterlantarkan dan pemberiannya dilakukan secara bertahap, HGU tidak diberikan sekaligus, misalnya, perusahan perkebunan memohon HGU seluas 20.000 hektar, maka luas yang diberikan pada tahap pertama adalah dua puluh lima persen atau seperempat dari luas yang dimohonkan yaitu seluas 5.000 hektar, setelah tanah ini seluruhnya diusahakan maka HGU tahap kedua diberikan misalnya 5000 hektar lagi, begitu seterusnya sampai seluas tanah yang dimohon HGUnya. Disamping itu, pemberian HGU secara bertahap ini juga untuk melihat itikad baik, kondisi keuangan dan kapasitas teknologi serta SDM perusahaan perkebunan pemohon HGU.

- Luar Jawa Sumatera

Untuk daerah ini mengingat masih luasnya tanah yang ada maka dimungkinkan untuk diberikan diatas 10-35 ha, dengan ketentuan harus sudah diusahakan baru dapat diajukan HGU, untuk menghindari tanah diterlantarkan dan pemberian HGU dilakukan secara bertahap.

Jangka waktu yang diberikan tidak ada perbedaan antara dua klasifikasi tersebut di atas, jangka waktu yang ada saat ini sudah cukup baik.

\subsubsection{Hak dan Kewajiban Pemegang HGU}

Hak dan Kewajiban Pemegang HGU sudah diatur dalam pasal 12 - 14 PP No. 40 tahun 1996 yaitu :

Pasal 12, Pemegang HGU berkewajiban untuk:

- membayar uang pemasukan kepada negara

- melaksanakan usaha pertanian, perkebunan, perikanan dan atau peternakan sesuai peruntukan dan persyaratan sebagaimana ditetapkan dalam keputusan pemberian haknya

- mengusahakan sendiri tanah HGU dengan baik sesuai dengan kelayakan usaha berdasarkan kriteria yang ditetapkan oleh instansi teknis 
- membangun dan memelihara prasarana lingkungan dan fasilitas tanah yang ada dalam lingkungan areal HGU

- memelihara kesuburan tanah, mencegah kerusakan SDA dan menjaga kelestarian lingkungan hidup sesuai dengan peraturan perundang-undangan yang berlaku

- menyampaikan laporan tertulis setiap akhir tahun mengenai penggunaan HGU

- menyerahkan kembali tanah yang diberikan dengan HGU kepada negara sesudah HGU hapus

- menyerahkan sertipikat HGU yang telah hapus pada Kepala Kantor Pertanahan

- Pemegang HGU dilarang menyerahkan pengusahaan tanah HGU kepada pihak lain kecuali dalam hal diperbolehkan menurut peraturan perundangundangan yang berlaku.

Pasal 14, tentang hak Pemegang HGU

- pemegang HGU berhak menguasai dan mempergunakan tanah yang diberikan dengan HGU untuk melaksanakan usaha di bidang pertanian, perkebunan, perikanan dan atau peternakan

- penguasaan dan penggunaan sumber air dan sumberdaya alam lainnya di atas tanah yang diberikan dengan HGU oleh pemegang HGU hanya dapat dilakukan untuk mendukung usaha sebagaimana dimaksud di atas dengan mengingat ketentuan peraturan perundang-undangan yang berlaku.

Hak dan Kewajiban Pemegang HGU dalam Peraturan Pemerintah di atas perlu diatur lebih lanjut dalam suatu peraturan pelaksanaan yang bersifat teknis seperti Peraturan Kepala BPN yang mengatur lebih lanjut hak dan kewajiban dari pemegang HGU dan mensinkronkannya dengan aturan yang ada di instansi lain (Departemen Pertanian cq Perkebunan). Perlu ditambahkan dalam kewajiban Pemegang HGU untuk membantu atau mengikut sertakan masyarakat sekitar dalam pengusahaan lahan perkebunan.

\subsubsection{Program Pemberdayaan Masyarakat}

Definisi Pemberdayaan Masyarakat, mengutip definisi yang dikemukakan oleh UNDP, Empowerment (pemberdayaan/penguatan) dianggap sebagai sebuah proses yang memungkinkan kalangan individual ataupun kelompok merubah keseimbangan kekuasaan dalam segi sosial, ekonomi maupun politik pada sebuah masyarakat ataupun komunitas. 
Kegiatan pemberdayaan dapat mengacu pada banyak kegiatan, di antaranya adalah meningkatkan kesadaran akan adanya kekuatan-kekuatan sosial yang menekan orang lain dan juga pada aksi-aksi untuk mengubah pola kekuasaan di masyarakat. Dari jenisnya, pemberdayaan/penguatan dapat dilihat pada dua level, individual dan komunitas. Pada tataran individual, isu-isu yang relevan dengan pemberdayaan adalah: hubungan patron-klien, gender, akses ke pemerintahan (negara), dan sumber-sumber kepemilikan properti. Sementara pada tataran komunitas, isu-isu utama yang biasa diangkat adalah: mobilisasi sumberdaya (resources mobilization), pemberdayaan/penguatan kerangka institusional dan akses hubungan (linkages) dengan badan-badan pemerintah.

Berkaitan dengan isu ini, UNESCO sendiri pernah mengungkapkan bahwa titik tekan tujuan pembangunan di masa depan adalah untuk membangun manusianya bukan pada membangun benda-benda yang bersifat fisik (the goals, aims and objectives of the development to be not to develop things but to develop people). Implikasinya adalah bahwa pembangunan haruslah lebih ditujukan pada peningkatan pencapaian spiritual, moral dan material manusia seutuhnya, baik selaku individual maupun sebagai bagian dari anggota masyarakat.3 Hal-hal itulah yang kemudian menjadi ranah pemberdayaan ataupun penguatan (empowerment).

Signifikansi pemberdayaan/penguatan pada tataran individual tentu saja berbanding lurus dengan pemberdayaan/penguatan pada tataran komunitas. Dalam hal ini, Friedmann bahkan menyebutkan bahwa pemberdayaan/penguatan pada tataran individual dan komunitas terkecil dalam masyarakat yaitu keluarga/rumah tangga, sangatlah penting. Bahkan ia mengistilahkan pemberdayaan/penguatan jenis ini sebagai pembangunan alternatif (the alternative development). Pemberdayaan/penguatan pada tataran individual dan keluarga pada gilirannya akan berimbas pada tataran masyarakat.

Keadilan dan kesejahteraan sosial sendiri merujuk kepada suatu kondisi sosial. Indikator-indikator yang biasa digunakan pun cukup jelas, diantaranya adalah angka kriminalitas, tingkat pengangguran, angka illiterasi di kalangan masyarakat, kemiskinan, dan lain sebagainya. Semakin rendah angka-angka tersebut menunjukkan bahwa suatu masyarakat memiliki tingkat kesejahteraan sosial yang tinggi, sebaliknya jika angkaangka hal-hal di atas semakin tinggi, dapat dipastikan pula tingkat kesejahteraan mereka semakin rendah. Kesejahteraan sosial pun sebetulnya pada awalnya. dapat diukur dari terpenuhinya kebutuhan-kebutuhan individual yang bersifat basic needs seperti sandang,pangan,papan,dan tentunya yang sangat penting juga adalah keamanan ataupun kedamaian.

Suatu masyarakat ataupun komunitas dapat dikatakan sejahtera jika kebutuhankebutuhan individual itu juga dapat terpenuhi dan tercapai pada level komunitas ataupun masyarakat. Pada tataran inilah, program-program community empowerment mendapatkan core-nya. Dengan program-program tersebut, kesejahteraan yang nantinya akan dicapai tidak hanya terkonsentrasi atau berputar di segelintir orang saja, tetapi haruslah dapat di-share dan dinikmati bersama. Untuk itu masyarakat harus sadar bahwasanya usaha-usaha tersebut tidak akan mampu terwujud jika tidak 
didahului oleh adanya kohesi sosial yang mampu membuat iklim sehat dan menyatukan antar individu di masyarakat secara harmonis.

Untuk terbentuknya kohesi sosial yang kuat di kalangan masyarakat/komunitas tersebut, tentu diperlukan adanya social capital yang cukup di kalangan masyarakat/komunitas tersebut. Mengutip Robert D.Putnam, social capital didefinisikan sebagai fitur-fitur organisasi-organisasi sosial seperti saling percaya (trust), hubungan timbale-balik (norms of reciprocity), dan jejaring (networks) yang dapat meningkatkan effisiensi di masyarakat dengan memfasilitasi program-program dan kegiatan-kegiatan secara bersama (collective actions). Putnam tampaknya terpengaruh pada teori civil society ala Tocquevillian yang meyakini bahwa adanya kelompok-kelompok di masyarakat yang bersifat bebas (voluntary associations) diantaranya dapat menjadikan kohesi di tingkat masyarakat akan semakin kuat, dan jika kohesi tersebut sudah kuat maka pada gilirannya akan mempermudah program-program community empowerment dijalankan.

Laporan hasil Penelitian Universitas Indonesia tahun 2006 menyebutkan bahwa program pemberdayaan masyarakat di bidang pertanahan sebagai upaya membangun kepercayaan diperlukan suatu konsep sistem inovasi di bidang pertanahan. Sistem inovasi yang didasarkan pada pendekatan sistemik, dibangun atas sinergi dengan unitunit terkait yang membentuk jaringan kerja dengan tugas, fungsi dan peran sesuai kompetensi, interaksi yang saling berhubungan dan saling menguatkan, untuk mencapai hasil sesuai tujuan pemberian Hak Atas tanah pada calon pemilik tanah. Pemberdayaan masyarakat pekebun dengan sistem inovasi dimaksudkan untuk memaksimalkan pemanfaatan tanah.

Untuk itu dalam proses penataan HGU diperlukan strategi pemberdayaan masyarakat. Strategi itu, meliputi: (i) pengembangan disain kemitraan usaha, (ii) Penguatan kelembagaan lelompok masyarakat sekitar lokasi HGU, (iii) Pengembangan fasilitas kredit bagi kelompok masyarakat dan (iv) Pengembangan mekanisme sosialisasi.

Berkaitan dengan hal tersebut, perlu ada upaya pemberdayaan masyarakat yang dilaksanakan oleh BPN baik di tingkat provinsi maupun kabupaten/kota dengan pembentukan POKMAS yang bersifat lokal dan berkelanjutan.

\subsection{Implikasi Kebijakan}

\subsubsection{Peraturan Perundangan dan Peraturan Pelaksanaannya}

Dalam UUPA, HGU dapat diberikan dalam jangka waktu 25 sampai 35 tahun, yang dapat diperpanjang dengan jangka waktu paling lama 25 tahun.Selanjutnya dapat diperbarui dengan jangka waktu 30 tahun. Jika semua syarat dipenuhi, penguasaan tanah di areal HGU dapat berlangsung selama 85 sampai 90 tahun. Persyaratan itu antara lain harus memakai investasi modal yang layak dan teknik pertanian yang baik sesuai dengan perkembangan zaman dengan maksud untuk mendorong supaya pemakaian dan pengusahaan tanahnya dilakukan secara efisien. 
Dengan adanya model penataan HGU yang akan dikembangkan tersebut di atas, pada prinsipnya tidak bertentangan dengan peraturan yang ada baik UUPA maupun PP No. 40 tahun 1996. Yang diperlukan adalah petunjuk teknis pelaksanaan berupa Peraturan Kepala BPN yang mengatur secara detail mengenai :

1. tahapan luasan dalam pemberian HGU, dengan tetap membedakan antara perorangan dan badan hukum

2. kewajiban yang harus ditambahkan pada perusahaan perkebunan, yaitu melakukan kemitraan dengan masyarakat disekitarnya, atau mempekerjakan masyarakat sekitarnya untuk membantu pemerintah mengatasi pengangguran dan mengentaskan kemiskinan.

Disamping hal tersebut di atas, yang sangat mendesak untuk segera dilakukan adalah penyempurnaan Peraturan Pemerintah No. 36 Tahun 1998 tentang Penertiban dan Pendayagunaan Tanah Terlantar, karena proses penertiban dalam PP ini panjang dan membutuhkan waktu serta memberikan peluang penghindaraan.

Patut menjadi perhatian dalam penataan HGU yaitu adanya kebijakan pemerintah dimana pemerintah telah mencanangkan revitalisasi pertanian, perikanan dan kehutanan. Sebagai tindak lanjut dari revitalisasi pertanian, perikanan dan kehutanan itu mulai tahun 2006 hingga tahun 2010 yang akan datang kita meluncurkan program revitalisasi perkebunan untuk komoditi kelapa sawit, karet dan cacao.

Program ini merupakan bagian dari upaya percepatan pembangunan perkebunan rakyat melalui perluasan, peremajaan dan rehabilitasi. Perluasan, peremajaan dan rehabilitasi itu didukung kredit perbankan dengan subsidi bunga oleh pemerintah. Program revitalisasi perkebunan ini juga melibatkan perusahaan-perusahaan di bidang perkebunan sebagai mitra petani dalam pembangunan kebun, dan pengolahan dan pemasaran hasil produksinya.

Untuk 5 tahun kedepan target atau sasaran dari program revitalisasi perkebunan adalah seluas 2 juta hektar. Jumlah itu meliputi perkebunan kelapa sawit 11/2 juta hektar yang akan kita perluas, perkebunan karet 300 ribu hektar dan cacao 200 ribu hektar. Program revitalisasi perkebunan ini diharapkan dapat menyerap tenaga kerja sebanyak 1 juta tenaga kerja.

Dewasa ini pemerintah juga sedang mempersiapkan program pengembangan tanaman penghasil bioenergi atau bahan bakar nabati. Untuk program itu direncanakan ada 4 komoditas yang akan dikembangkan yaitu kelapa sawit dan jarak pagar untuk substitusi atau pengganti minyak solar serta tebu dan ubi kayu untuk menghasilkan etanol sebagai substitusi premium.

Target yang akan dikembangkan adalah 11/2 juta hektar untuk perkebunan kelapa sawit, 
$11 / 2$ juta hektar untuk tanaman jarak pagar, 11/2 juta hektar untuk ubi kayu dan 750 ribu hektar untuk perkebunan tebu. Pengembangan tanaman penghasil bio energi itu atau bahan bakar nabati itu diharapkan akan mampu menyerap lebih kurang 3 juta tenaga kerja.

Pembiayaan pengembangan energi nabati dan revitalisasi perkebunan sebagaimana disebutkan di atas telah didukung penyediaan subsidi bunga sesuai peraturan Menteri Keuangan No. 117 tahun 2006. Petani, pekebun hanya berkewajiban membayar bunga kredit investasi sebesar $10 \%$ selama masa pembangunan 5 tahun untuk kelapa sawit dan cacao serta 7 tahun untuk karet. Selisih bunga antara bunga komersial dan bunga perbankkan akan menjadi tanggungan pemerintah. Ini salah satu upaya untuk membantu sektor pertanian, salah satu upaya untuk membantu para petani.

\subsubsection{Mekanisme Penataan}

Reforma agraria sebagai salah satu misi pertanahan yaitu pemberdayaan masyarakat dengan harapan tercapai kemakmuran yang sebesar-besarnya bagi rakyat. Selain mendorong pemilikan tanah bagi masyarakat miskin baik dalam pemilikan tanah secara individu, kolektif maupun dalam bentuk HGU/HGB diperlukan suatu komitmen dari Pemerintah dalam hal ini BPN sebagai institusi yang bertugas mengelola pertanahan, sehingga pemberian tanah Hak Atas Tanah bukanlah bagi-bagi tanah Negara tetapi dilakukan untuk meningkatkan pendapatan Negara dari pajak pertanahan yang secara nyata diperlukan untuk kelanjutan pembangunan nasional.

Kebijakan pertanahan dalam penataan Hak Guna Usaha (HGU) masih menyimpan banyak persoalan. Hal ini terjadi mengingat banyaknya kepentingan terhadap tanah HGU tersebut. Banyaknya kepentingan ini mewujud dalam munculnya berbagai persoalan pertanahan yang terkait dengan aspek kebijakan, sosial dan ekonomi. Dalam aspek kebijakan, pemerintah cenderung lebih berorientasi pada perkebunan dengan skala besar dibanding usaha perkebunan rakyat. Orientasi yang seperti ini sangat tidak relevan dengan keterbatasan luasan yang dimilik.

Di sisi yang lain, HGU dengan skala besar cenderung lebih banyak memunculkan tanah terlantar. Terlantarnya tanah di kawasan HGU inilah yang kemudian memunculkan berbagai konflik, baik konflik akibat pendudukan, reclaiming maupun konflik penggunaan tanahnya. Implikasi adanya konflik dan sengketa pertanahan di kawasan HGU ini adalah tidak optimalnya produktivitas pemegang HGU dan munculnya penguasaan-penguasaan tanah HGU secara ilegal. Dalam konteks ini, apabila persoalan pengelolaan tanah HGU belum dapat terselesaikan, ia akan kontraproduktif terhadap agenda pembaruan agraria nasional yang sedang digulirkan BPN RI.

Oleh karena itu mekanisme penataan HGU harus dilaksanakan dalam kerangka pencapaian tujuan reforma agraria. pemberian HGU harus tetap memperhatikan factor yang harus dilaksanakan oleh pemegang HGU, tidak hanya menyangkut haknya, tetapi juga memberikan kewajiban kepada pemegang HGU tersebut untuk menggunakan dan memanfaatkan tanahnya sesuai dengan keadaan, sifat dan tujuan pemberiannya guna 
memperoleh manfaat usahanya sekaligus juga memberi manfaat kepada masyarakat sekitarnya. Maka diperlukan upaya secara jurudis sekaligus sosiologis dan ekonomis dalam suatu kelembagaan koordinatif.

Agar hal ini dapat tercapai perlu dilakukan langkah-langkah: pertama, melakukan identifikasi dan inventarisasi serta menyusun data base tanah perkebunan besar (HGU) di seluruh Indonesia, kedua, melakukan penertiban tanah HGU yang diterlantarkan kembali menjadi tanah yang dikuasai langsung oleh Negara, ketiga, mengalokasi tanah HGU tersebut kepada pihak lain yang membutuhkan untuk didayagunakan - termasuk petani tidak bertanah (the best use of land).

Untuk mewujudkan hal tersebut di atas perlu ada kerja sama antara pemegang HGU, BPN dan instansi yang terkait. Untuk itu diperlukan koordinasi yang intensif dengan instansi terkait seperti Pemerintah dan Dinas Perkebunan. Koordinasi tersebut harus dituangkan dalam sutau kebijakan yang bersifat komprehensif, tidak sektoral.

\subsubsection{Kelembagaan Penataan}

Definisi kelembagaan menurut Bromley mencakup tiga hal penting, yaitu (1) norma dan konvensi (norms and conventions);(2) aturan main (rules of the game), dan hubungan kepemilikan (property relations). Kelembagaan mencakup hal-hal yang tidak tertulis seperti aturan adat, norma dan sistem nilai yang dianut masyarakat dan mencakup sesuatu yang ditulis secara formal dan ditegakkan oleh aparat Pemerintah.

Secara umum pengembangan kelembagaan adalah proses perencanaan dan pembinaan terhadap suatu organisasi dengan cara membangun keterkaitan dan saling memperkuat di antara fungsi organisasi sehingga memberi dampak positif secara fisik dan sosial terhadap suatu lingkungan tertentu. Strategi ini dikembangkan untuk mencapai tujuan sistem sosialisasi pengelolaan tanah Hak Guna Usahar yang dapat diterima masyarakat secara demokrasi, tanpa distorsi dengan menumbuh-kembangkan partisipasi masyarakat. Arah pengembangan melalui penguatan keterkaitan individu dengan kelembagaan masyarakat setempat serta strategi pengembangan kelembagaan Pokmas yang berfokus kepada penguatan sistem komunikasi dan informasi kegiatan ke masyarakat.

Pembenahan atau penataan kelembagaan tidak akan berhasil tanpa melakukan penataan aset dan penguatan aset sekaligus memerlukan sinergi kebijakan yang tidak sederhana. Untuk itu penataan HGU dalam rangka reforma agraria memerlukan suatu perangkat peraturan perundangan yang cukup kuat dan mampu mengikat semua kepentingan. Untuk itu diperlukan peraturan perundangan yang secara khusus mengatur penyelenggaraan reforma agraria sehingga pelaksanaan dan produk yang dihasilkan dapat menjamin kepastian hukum.

Bustanil Arifin dalam makalahnya yang disampaikan pada seminar Nasional "Reforma Agraria dan Pembangunan Ekonomi Indonesia, 2007, mengusulkan beberapa opsi pembenahan aransemen kelembagaan menuju reforma agraria yang efektif, yaitu (1) prioritas revitalisasi kelembagaan internal BPN dan instansi pemerintah lain yang 
berhubungan langsung dengan reforma agraria, (2) melaksanakan pemberian sertipikasi lahan milik bagi petani kecil dan buruh tani (secara cuma-Cuma) melalui sebuah badan layanan umum (BLU) yang dikuatkan dengan peraturan perundangan yang kuat dan berwibawa, (3) peningkatan akses untuk mengembangkan skala ekonomi petani, seperti dukungan pembiayaan usaha(terutama pertanian), teknologi baru, informasi kesesuaian lahan, pendidikan petani, akses pasar dan pemasaran, (4) perumusan sistem insentif (dan disinsentif) bagi pemilik tanah dan pemerintah daerah setempat yang mampu mencapai target-target penguatan aset dan pemberdayaan ekonomi masyarakat, (5) memfasilitasi penyusunan kebijakan tata ruang wilayah (RTRW) yang mendukung strategi reforma agraria, yang dapat dijadikan acuan dalam penerbitan ijin lokasi yang tidak bertentangan dengan prinsip-prinsip keadilan dan pemerataan, (6) mengalokasikan dana dekonsentrasi untuk merumuskan kebijakan daerah yang mampu merangsang (dan melindungi) tanah pertanian, terutama sawah beririgasi teknis dengan peraturan yang mengikat dengan sanksi yang tegas.

Apa yang dikemukakan di atas, tentunya bukan pekerjaan yang mudah, perlu waktu, komitmen dan konsistensi untuk mewujudkan reforma agraria yang dapat memberikan keadilan yang seadil-adilnya bagi seluruh lapisan masyarakat, sebagaimana dicanangkan dalam Rencana Program pembangunan Jangka Menengah tahun 20042009 yang meletakkan strategi reforma agraria sebagai salah satu upaya untuk mengentaskan masyarakat dari kemiskinan dengan meningkatkan kepastian hukum hak atas tanah bagi masyarakat miskin tanpa diskriminasi gender, mengembangkan mekanisme perlindungan terhadap hak atas tanah bagi kelompok rentan dan paling penting adalah mengembangkan mekanisme redistribusi tanah secara selektif.

\section{BAB VI}

\section{KESIMPULAN DAN REKOMENDASI}

\subsection{Kesimpulan}

1. Kebijakan HGU yang ditetapkan dalam UUPA dan PP Nomor 40 Tahun 1996 lebih berorientasi pada pengaturan HGU sebagai usaha besar, dimana hak-hak masyarakat sekitar belum memperoleh peluang untuk meningkatkan kesejahteraannya. Hal ini diindikasi dengan:

a. Luas maksimum HGU yang dapat diberikan kepada perorangan maksimal 25 ha dan minimal 5 ha, sedangkan usaha perkebunan rakyat bisa kurang dari 5 ha sehingga menutup kemungkinan perorangan memiliki HGU kurang dari 5 ha.

b. Dari 6 provinsi sampel, batas minimum luasan HGU yang pernah diberikan ada di Kabupaten Kampar yaitu 17.81 ha dan merupakan HGU Perorangan.

c. HGU dapat diberikan dalam jangka waktu 35 tahun, diperpanjang dan diperbarui sampai lebih kurang 80 tahun 
2. Jangka waktu yang secara langsung diberikan dalam waktu yang cukup lama (25 tahun atau 35 tahun untuk tanaman keras) mengakibatkan pemanfaatan tanah kurang optimal, bahkan kemungkinan diterlantarkan oleh pemegang HGU. sebaiknya ada uji coba 5 tahun pertama baru diberikan selebihnya (20 tahun) jika dikerjakan dengan baik.

3. Demikian halnya dengan luasan HGU, sebaiknya pemberian HGU tidak langsung diberikan dalam skala yang sangat luas, tapi dilakukan secara bertahap, cukup diberikan pertama 5000 ha dulu jika diusahakan dengan baik baru ditambah luasannya. Untuk masyarakat sebenarnya diberikan luasan 2 ha saja sudah cukup memadai. Dalam program revitalisasi perkebunan lahan untuk pengembangan perkebunan untuk masing-masing petani peserta paling luas atau maximum 4 ha.

4. Kebijakan pengembangan HGU juga didukung oleh kebijakan sektoral seperti a)UU Perkebunan dan peraturan pelaksanaannya seperti Peraturan Menteri, b) kebijakan perbankan yang mengatur pemberian kredit untuk pelaksanaan revitalisasi perkebunan yang dilaksanakan pada tanah HGU serta c) adanya kebijakan lokal yang dikeluarkan oleh Pemerintah Daerah.

5. Ditinjau dari aspek penguasaan dan pemanfaatan tanah HGU Dari 6 provinsi lokasi sampel menunjukkan luasan HGU yang terbesar ada di Sumatera Utara dengan luas 1061718,503 ha $(36,46 \%)$. Luas HGU yang maximal pernah diberikan juga ada di Sumatera Utara yaitu 26000,0000 ha. Setelah Sumatera Utara, adalah Riau yang mempunyai luas HGU sebesar 909429,47 ha $(31,23 \%)$. Kalimantan yang mempunyai luas wilayah terbesar, luasan HGU nya lebih kecil dari Riau yaitu sebesar 739998,613 ha $(25,41 \%)$. Provinsi Jambi berada di bawah Kalimantan Timur dengan luas sebesar 187881,04 ha (6,45\%), kemudian Gorontalo dengan luas Hak Guna Usaha sebesar 10794,9438 ha $(0,37 \%)$ dan terakhir adalah Provinsi Bali dengan luas HGU sebesar 2 417,4814 ha (0,08\%). Sedangkan dari aspek pemilikan tanah HGU sebagian besar dikuasai oleh Badan Hukum yang umumnya PMDN, sedangkan pemiikan oleh perorangan kurang dari $10 \%$.

6. Dalam pelaksanaan pemberian HGU masih terdapat hal-hal yang belum sesuai dengan tujuan reforma agraria, antara lain :

a. Masih banyak dijumpai semakin luas HGU yang dikuasai cenderung semakin banyak tanah yang diterlantarkan

b. Masih banyak masalah atau sengketa dan konflik pertanahan di atas tanah HGU terutama pada lokasi yang sudah berakhir jangka waktu HGU nya. Banyaknya konflik tanah HGU, antara lain disebabkan (1)adanya tanah HGU yang telah habis masa berlakunya, namun belum diajukan permohonan perpanjangan hak, karena terjadi perebutan penguasaan,(2) adanya okupasi masyarakat disekitar tanah HGU karena tanah HGU diterlantarkan atau tidak dimanfaatkan secara optimal, (3) adanya klaim 
masyarakat bahwa pemegang HGU belum membayar ganti rugi atas tanah HGU yang diklaim sebagai miliknya

c. Masih banyak masyarakat miskin di sekitar perkebunan.

7. Terjadinya konflik antara masyarakat dengan perusahaan perkebunan dapat terjadi karena kurangnya pemahaman masyarakat terhadap hukum pertanahan. Oleh karenanya untuk memberikan pemahaman kepada masyarakat maka perlu dilaksanakan program pemberdayaan. Selama ini BPN sudah mengembangkan kegiatan pemberdayaan masyarakat baik melalui program POKMASDARTIBNAH maupun program lainnya. Pemberdayaan kelompok masyarakat sadar dan tertib pertanahan (POKMAS) sebagai institusi lokal merupakan langkah penting dalam meningkatkan partisipasi masyarakat dalam pengelolaan pertanahan secara mandiri. Langkah pemberdayaan dilakukan melalui sosialisasi dan penyuluhan tentang hukum pertanahan. Sosialisasi dan penyuluhan tersebut selanjutnya diharapkan dapat meningkatkan pengetahuan dan kesadaran masyarakat akan pentingnya swakelola pertanahan. Dalam POKMAS inilah partisipasi masyarakat akan ditingkatkan dengan memberikan pemahaman akan hak dan kewajiban dalam kepemilikan tanah, upaya mandiri dalam menyelesaikan sengketa atau konflik tanah tanpa harus melibatkan lembaga lain seperti peradilan.

8. Pemanfaatan tanah HGU Perkebunan memberikan andil yang sangat berarti dalam mendukung program pengentasan kemiskinan karena sektor pertanian memiliki peranan penting dalam perekonomian daerah khususnya perkebunan yang saat ini giat mengembangkan tanaman kelapa sawit, karet dan kakao, dengan pertimbangan komoditi tersebut mempunyai peranan yang sangat strategis sebagai sumber pendapatan, mempunyai prospek pasar, mampu menyerap tenaga kerja dan mempunyai peranan dalam pelestarian fungsi lingkungan hidup. Sektor perkebunan terutama di Sumatera mampu memberikan kontribusi yang cukup tinggi terhadap PDRB.

9. Beberapa model penataan HGU perkebunan terkait pembangunan wilayah secara nasional, regional dan lokal yang ditemukan antara lain:.

a. Model inti Plasma,

Tanah disewakan oleh perusahaan, setelah jadi kebun, dilakukan penilaian oleh TP3D (tim Penilai Kebun) layak atau tidak, jika dinilai layak maka hasil dari kebun dikembalikan untuk membayar kredit $30 \%$ kepada perusahaan, $70 \%$ untuk petani.

b. Model KKPA

Dibentuk koperasi yang mewakili kelompok tani, di dalam kelompok tani ada masyarakat, masyarakat mempunyai lahan garapan diserahkan pada perusahaan untuk membangun kebun sampai produksi, dengan perjanjian perusahaan mendapat $30 \%$, masyarakat mendapat 70 , dengan dibebani kredit dari membangun kebun untuk 
perusahaan melalui bapak angkat (Bank Mandiri, BRI atau BNI). Kalau sudah layak dikonversi menjadi Hak Milik dan diredistribusikan, sertipikat Hak Milik yang dijaminkan.

c. Kerjasama Operasional (KSO),

merupakan hubungan kemitraan yang di dalamnya kelompok mitra menyediakan lahan, sarana dan tenaga kerja, sedangkan perusahaan mitra menyediakan biaya atau modal dan/atau sarana untuk mengusahakan atau membudidayakan suatu komoditi perkebunan.

\section{d. Kemitraan terpadu hulu-hilir}

Kemitraan dengan melalui konsolidasi tanah dimana tanah masyarakat yang merupakan tanah negara yang telah dikuasai oleh masyarakat dibangun menjadi kebun kelapa sawit. Petani yang memiliki tanah kurang atau lebih dari 3 hektar, dikenakan ketentuan penetapan calon lahan (CL).

Setelah lahan dibangun menjadi kebun sawit siap panen, maka baru diserahkan kepada petani di mana setiap rumahtangga petani yang terlibat akan menerima tanah seluas 3 hektar (di sini terletak sisi redistribusi lahannya).

\subsection{Rekomendasi}

1. Kebijakan HGU perlu direvisi baik mengenai luasan, maupun jangka waktu pemberian

2. Luasan HGU sebaiknya dibagi dalam dua klasifikasi yaitu (1) Jawa Sumatera

luasan perlu dibatasi hanya diberikan antara 5-25 ha (max 35 ha), dengan ketentuan harus sudah diusahakan baru dapat diajukan HGU, untuk menghindari tanah diterlantarkan dan pemberiannya dilakukan secara bertahap. (2) Luar Jawa Sumatera, untuk daerah ini mengingat masih luasnya tanah yang ada maka dimungkinkan untuk diberikan diatas 10-35 ha, dengan ketentuan harus sudah diusahakan baru dapat diajukan HGU, untuk menghindari tanah diterlantarkan dan pemberian HGU dilakukan secara bertahap.

3. Pola kemitraan yang ada sekarang merupakan kebijakan yang dibuat oleh Departemen Pertanian (Perkebunan), sebaiknya kebijakan ini juga diintegrasikan dengan kebijakan BPN, melalui Program Pembaruan Agraria.. Kebijakan ini juga harus dikuatkan dengan adanya sanksi untuk memelihara tanah dan kebun yang sudah diberikan sehingga tidak akan dimanfaatkan oleh para spekulan. Apabila tidak dimanfaatkan dapat mengalokasikan tanah HGU tersebut kepada pihak lain yang membutuhkan untuk didayagunakan termasuk petani tidak bertanah (the best use of land).

4. Perlu adanya petunjuk teknis pelaksanaan berupa Peraturan Kepala BPN yang mengatur secara detail mengenai : 
- tahapan luasan dalam pemberian HGU, dengan tetap membedakan antara perorangan dan badan hukum

- kewajiban yang harus ditambahkan pada perusahaan perkebunan, selain melakukan kegiatan sesuai dengan tujuan usahanya, wajib melakukan kemitraan dengan masyarakat disekitarnya, atau mempekerjakan masyarakat sekitarnya untuk membantu pemerintah mengatasi pengangguran dan mengentaskan kemiskinan.

5. Dalam proses penataan HGU diperlukan strategi pemberdayaan masyarakat. Strategi itu, meliputi: (i) pengembangan disain kemitraan usaha, (ii) Penguatan kelembagaan lelompok masyarakat sekitar lokasi HGU, (iii) Pengembangan fasilitas kredit bagi kelompok masyarakat dan (iv) Pengembangan mekanisme sosialisasi. Berkaitan dengan hal tersebut, perlu ada upaya pemberdayaan masyarakat yang dilaksanakan oleh BPN baik di tingkat provinsi maupun kabupaten/kota dengan pembentukan POKMAS yang bersifat lokal.

\section{DAFTAR PUSTAKA}

\section{A. Buku/Laporan/Makalah}

Achmad Sodiki, Empat Puluh Tahun Masalah Dasar Hukum Agraria, Pidato Pengukuhan Guru Besar , 17 Juni 2000.

A.P. Parlindungan, 1981, Problem Hak-Hak Tanah di Sumatera Utara Kepada Selekta Hukum Agraria, Penerbit Alumi.

Ari Sukanti Hutagalung, 2001, Penyelesaian Sengketa Tanah Menurut Hukum Yang Berlaku, makalah dalam loka karya Pertanahan : Pengadaan dan Pemanfaatan di Bidang Migas Demi terciptanya Kenyamanan Investasi, Batam Tanggal $8 \mathrm{~s} / \mathrm{d}$ Agustus 2001

Badan Pertanahan Nasional, Penertiban dan Pendayagunaan Tanah Terlantar, Makalah Konsultasi Publik, Penyempurnaan Peraturan Pemerintah No.36 tahun 1998, Jakarta, Maret 2004

E.De.Vries. Masalah Masalah Petani Jawa, terjemahan, Ny.P.S.Kusumo Sutojo, Bhratara, Jakaarta, 1972.

Endriatmo Soetarto \& Moh. Shohibuddin. Membangun Kultur Baru Pengelolaan Hgu Untuk Mendorong Terwujudnya Transformasi Ekonomi Pedesaan Yang Kokoh, makalah disampaikan pada acara Seminar Nasional Pertanahan yang diselenggarakan Sekolah Tinggi Pertanahan Nasional pada tanggal 12 April 2007 di Jogyakarta

Engelbrecht, De Wetten en Verordeningen van Indonesie, Leiden hal.1616. 
Kuntowijoyo, Radikalisasi Petani, Penerbit Bentang Intervensi Utama, Cetakan Pertama , Yogyakarta, 1993.

Boedi Harsono, 1997, Hukum Agraria Indonesia, Sejarah Pembentukan Undangundang Pokok Agraria, Isi dan pelaksanaannya, Djambatan. Jakarta.

Boedi Harsono, 2000, Hukum Agraria Indonesia, Himpunan Peraturan-peraturan Hukum Tana, Djambatan. Jakarta.

Boedi Harsono, 2002, Menuju Penyempurnaan Hukum Tanah Nasional, Jakarta Tri Sakti.

Rehngena Purba, 2007, Putusan Pengadilan Dalam Sengketa Pertanahan/ Hak Guna Usaha, makalah disampaikan pada acara Seminar Nasional Pertanahan yang diselenggarakan Sekolah Tinggi Pertanahan Nasional pada tanggal 12 April 2007 di Jogyakarta

Risnarto, 1999. Pengelolaan Pertanahan. Pusat Penelitian dan Pengembangan Badan Pertanahan Nasional. 2005 Laporan penelitian Mengenai Tanah Terlantar. Tidak Dipublikasi

\section{.B. Peraturan}

Undang-Undang Nomor 5 Tahun 1960 Tentang Peraturan Dasar Pokok-Pokok Agraria. Undang-Undang Nomor 18 tahun 2007 tentang Perkebunan

Peraturan Pemerintah No.40 Tahun 1996 tentang Hak Guna Usaha, Hak Guna Bangunan dan Hak Pakai atas Tanah

Peraturan Menteri Negara Agraria/Kepala Badan Pertanahan Nasional No. 3 Tahun 1999 tentang Pelimpahan Kewenangan Pemberian dan Pembatalan Keputusan Pemberian Hak atas Tanah;

Peraturan Menteri Negara Agraria/Kepala Badan No. 9 Tahun 1999 tentang Tata Cara Pemberian dan Pembatalan Hak atas Tanah Negara dan Hak Pengelolaan.

Keputusan Menteri Pertanian Nomor 486.1/Kpts/OT.100/10/2003 tentang Pedoman Klasifikasi Perusahaan Perkebunan.

Peraturan Menteri Pertanian Nomor 33/Permentan/OT.140/7/2006 tentang Pengembangan Perkebunan melalui Program Revitalisasi Perkebunan

Peraturan Menteri Pertanian Nomor 26/Permentan/OT.140/2/2007 tentang Pedoman Perizinan Usaha Perkebunan. 
